\title{
Staðgreiðsla og skattbyrði í 30 ár
}

\author{
Axel Hall ${ }^{1}$
}

\begin{abstract}
Ágrip
Í pessari grein er markmiðið að lýsa núverandi skattkerfi tekjuskatts sem hefur verið við lýði frá upptöku staðgreiðslunnar 1988. Hér er kerfið greint, eiginleikum pess lýst og раð аð einhverju leyti sett í norrænt samhengi. Til að auðvelda umfjöllun eru settar fram formlegar skilgreiningar á skattbyrði og jaðarsköttum. Mælikvarðar á jöfnun skattkerfis eru ennfremur settir fram. Pegar litið er yfir allt tímabil staðgreiðslunnar sést að tengsl persónuafsláttar við vísitölu neysluverðs á tímum hækkunar kaupmáttar hafa aukið meira skattbyrði hjá hinum tekjulægri en peim sem hafa hærri tekjur, sem á móti voru með hærri skattbyrði fyrir. Pessi próun er hér nefnd raunskattskrið og langtímapróun í pessu efni hefur yfirgnæft aðra hluta staðgreiðslukerfisins og greiðendum tekjuskatts hefur fjölgað. Framangreindar breytingar hafa verið umdeildar og fræðimenn m.a. tekist á um pær. Hér er próuninni lýst án pess að leitast við að leggja dóm á pá pólitísku vegferð sem hefur verið farin eða vangaveltur um aðrar leiðir mögulegar hingað til. Rauði práðurinn hefur verið próun skattleysismarka og persónuafsláttar. Kerfi með framangreindri próun parf að endurstilla reglulega standi vilji til að viðhalda lóðréttri jöfnun í kerfinu. Pað kallar á stefnumótun um prep (stig og fjölda), mörk prepa (t.a.m. skattleysismörk) og próun markanna yfir tíma. Í pessari grein er farið yfir pá valkosti sem stjórnvöld hafa sett fram varðandi breytingar á skattkerfinu og niðurstaða peirrar stefnumörkunar greind með áhrifum á jöfnun í kerfi tekjuskatts.
\end{abstract}

\section{Abstract}

This paper describes the income tax system of pay as you go from its introduction in 1988. An analysis of the system is given, and its main characteristics, which are then put into Nordic context. To clarify the analysis this paper gives formal definitions of tax burden and marginal taxes. Measures for the progressiveness of the tax system are formulated and applied to the latest tax changes. Generally, since 1988 the indexation of the tax credit to general price increases has been the overriding factor in the development of the system and the tax burden. The tax burden has increased more for lower income people than for those on higher income. This occurrence is defined as real fiscal drag and resulted in more people

1 Dr. Axel Hall er lektor við Háskólann í Reykjavík. Netfang: axelhall@ru.is. Höfundur er jafnframt varaformaður fjármálaráðs. Greinin er á ábyrgð höfundar og parf ekki að endurspegla skoðanir fjármálaráðs. Höfundur vill pakka Mariönnu Jónasdóttur fv. skrifstofustjóra á skrifstofu skattamála í fjármála- og efnahagsráðuneytis fyrir samstarf og ábendingar sem nýttust við skrif pessarar greinar er byggir á vinnu skýrslu sérfræðingahóps um endurskoðun skattkerfisins. Höfundur var formaður sérfræðingahópsins og vann að gerð skýrslunnar, (fjármála- og efnahagsráðuneytið, 2019). Pá vill höfundur pakka Hlyni Hallgrímssyni sérfræðingi á skrifstofu skattamála sérstaklega fyrir samstarf um ýmsa pá útreikninga og gögn sem hér birtast. Ágúst Arnórsson verkefnisstjóri á Hagfræðistofnun Háskóla Íslands fær líka bestu pakkir fyrir veitta aðstoð við skrif pessara greinar. Villur eru á ábyrgð höfundar.

This work is licensed under a Creative Commons Attribution 4.0 License.

DOI: https://doi.org/10.24122/tve.a.2019.16.2.4

(C) Tímarit um viðskipti og efnahagsmál 
paying tax. These changes have not been without controversy politically and among academics. The evolution of the system is described here without making a judgment of the political decisions that preceded the changes in the system. The underlying current has been the evolution of the allowance and the tax credit. A system with such a current needs to be recalibrated at regular intervals if it is to achieve vertical equity. That calls for policy making on tax rates, (the level of rates and the number of steps) and how the allowance and other reference amounts in the system evolve over time. This paper gives an overview of the options that the government has been giving consideration to during the latest round of evaluation of the system. The policy changes that is now under consideration is evaluated in terms of the proposed changes in progressiveness of the system.

JEL flokkun D31; D63; H21; H22; H24; H25; H27.

Lykilorð: Fjármál hins opinbera; tekjuskattar; skattbyrði; jöfnun skattkerfis.

Keywords: Public finance, income tax; tax burden; progressiveness.

Pay as you go income tax system and tax burden for 30 years

\section{Inngangur}

Skattar eru meðal viðkvæmustu og umdeildustu viðfangsefna í samfélagi á hverjum tíma. Fjármögnun hins opinbera og endurdreifing tekna sem peir eru notaðir til eru stjórnmálalegt viðfangsefni sem tekist er á um í kosningum og á vettvangi stjórnmála. Hið norræna líkan skatta og opinbers rekstrar er um margt ólíkt öðrum kerfum. Annars vegar hversu mikil endurdreifing er og umfang opinbers rekstrar og hins vegar stig skattlagningar.

Tekjuskattar á Norðurlöndum eru almennt háir og kerfin búa almennt við stigmögnun hækkandi skatta með auknum tekjum. Petta hefur náðst án pess að pað hafi komið niður á atvinnustigi eða með háu atvinnuleysi. Góða yfirlitsgrein um petta er að finna í Barth og fél. (2014) par sem pessari tölfræði er lýst.

Í umræðu um opinber fjármál hér varðandi útgjöld og tekjuöflun er samanburður við hin Norðurlöndin iðulega nálægur. Í pessari umræðu takast á sjónarmið um jöfnuð og um skilvirka skatta og möguleg fórnarskipti á milli pess að stuðla að hagkvæmu skattkerfi og skattkerfi sem stuðlar að endurdreifingu tekna. Hægt er að stuðla að jöfnuði með skattlagningu en útgjaldastefnu hins opinbera hefur auðvitað líka veruleg áhrif á jöfnuð pó pað sé ekki greint hér.

Í pessari grein er markmiðið að lýsa núverandi skattkerfi tekjuskatts sem hefur verið við lýði frá upptöku staðgreiðslunnar 1988. Hér er kerfið greint, eiginleikum pess lýst og pað sett í norrænt samhengi. Til að auðvelda umfjöllun eru settar fram formlegar skilgreiningar á skattbyrði og jaðarsköttum. Mælikvarðar á jöfnun skattkerfis eru settir fram og peim beitt á pær breytingar sem framundan eru. Jöfnun í skattkerfi vísar almennt til pess að greiddur sé hærri skattur af auknum tekjum. Hér er vert að staldra við og skilgreina hvað felst í hugtakinu jöfnuður.

Almennt má segja að tekjudreifing er mæld með hlutfalli hárra og lágra tekna, t.d. tekna pess sem er neðst í efstu tíund og pess sem er efst í neðstu tíund, en ekki mismun. Yfir langan tíma margfaldast tekjur hvers einstaklings og verður pá munur í krónum meiri en hlutföllin haldast svo fremi sem tekjudreifingin breytist ekki. Hlutfallslegur tekjuskattur minnkar krónutölumun á milli einstaklinga af pví að peir tekjuháu greiða pá fleiri krónur í skatta en hefur ekki áhrif á hlutaföll ráđstöfunartekna og par með ekki á tekjudreifingu eins og hún er mæld. Pess vegna parf tekjuskattur að vera „prógressífur“ búa við stigmögnun til pess að lækka hlutfall hæstu og lægstu ráðstöfunartekna.

Duclos (2008) skilgreinir og skýrir hugtökin lóðréttur og láréttur jöfnuður. Hann bendir á að litið sé til pessara tveggja grunngilda við greiningu á áhrifum endurdreifingar stjórnvalda. Lóðréttur jöfnuður aðstoðar við að greina hvernig aðgerðir hafi áhrif á jöfnuð ein- 
staklinga sem hafi upphaflega mismunandi velferð. Stuðst er við láréttan jöfnuð pegar metin eru áhrif stefnumörkunar stjórnvalda á aðila sem eru eins á öllum viðeigandi sviðum - p.m.t. með sama stig upphaflegrar velferðar. Hvað skattlagningu varðar krefst grunngildið um lóðréttan jöfnuð að hrein skuldbinding skattgreiðslna vaxi með aukinni getu einstaklinga til að greiða (mælt með tekjum fyrir skatt). Strangt form pessa grunngildis er samkvæmt Duclos almennt viðtekið: pað felur í sér að getan til að greiða vaxi hraðar en tekjur, og að hrein skattbyrði ætti samkvæmt pví einnig að vaxa hraðar en tekjur. Á grundvelli pessa felur strangt form lóðrétts jafnaðar í sér stigmögnun í skattkerfinu. Hér er umræða um lóðréttan jöfnuð byggð á skilgreiningu Duclos eins og hún birtist í The New Palgrave Dictionary of Economics og jöfnun í greininni vísar til pessa stranga forms lóðrétts jafnaðar.

Jöfnun má ná fram með hækkandi jaðarsköttum með auknum tekjum og/eða með pví að undanpiggja ákveðinn hluta tekna sköttum p.e. setja ákveðin skattleysismörk. Skattleysismörk eru pau tekjumörk par sem persónuafsláttur er fullnýttur. Pau ákvarðast af grunnprósentu og persónuafslætti.

Pegar litið er yfir allt tímabil staðgreiðslunnar sést að tengsl persónuafsláttar við vísitölu neysluverðs á tímum hækkunar kaupmáttar hafa aukið meira skattbyrði hjá hinum tekjulægri en peim sem hafa hærri tekjur, sem á móti voru með hærri skattbyrði fyrir. Pessi próun er hér nefnd raunskattskrið og langtímapróun í pessu efni hefur yfirgnæft aðra hluta staðgreiðslukerfisins og greiðendum tekjuskatts hefur fjölgað.

Persónuafsláttur var hár í upphafi staðgreiðslunnar 1988 og einnig grunnprósentan. Við upphaf staðgreiðslunnar varð sögulegt lágmark í tekjuöflun tekjuskatts. Kerfisbundið hefur verið leitast við að vinda ofan af pessu bæði hvað varðar há skattleysismörk og háa grunnprósentu. Há prósenta gerir pað að verkum að pegar tekjur fara yfir skattleysismörk lenda framteljendur á vegg skattprósentu með tilheyrandi letjandi áhrifum á vinnuframboð.

Almennt hefur skattkerfið jöfnunareiginleika innan árs gagnvart ólíku tekjustigi (lóðréttur jöfnuður) en raunskattskriðið hefur einnig leitt til jöfnunar á skattbyrði yfir tíma (flatara skattkerfi). Raunskattskriðið hefur enn fremur reynst öflugt og virkt hagstjórnartæki sem eykur skattbyrði á penslutíma en dregur úr pegar laun halda ekki í við vísitölu verðlags. A petta reyndi verulega eftir fjármálaáfallið 2008. Sumt í tekjuöflun hins opinbera hrundi en á sama tíma gaf ríkið eftir skattbyrði til að milda áhrif skattlagningar á almenning. Skattleysismörk hækkuðu pá meira en laun og um leið jukust ýmis útgjöld bótakerfa í tengslum við efnahagsástandið með samsvarandi skuldasöfnun ríkissjóðs. Tímabilið eftir pað hefur farið í að greiða skuldir ríkissjóðs með bættu efnahagsástandi.

Framangreindar breytingar hafa verið umdeildar og fræðimenn tekist á um pær. Stefán Ólafsson (2007) greinir t.a.m. skattastefnu Íslendinga og ber saman við önnur lönd innan OECD. Í grein sinni ber hann próun skattlagningar á Íslandi saman við próun annars staðar á breiðum grunni með ýmsum mælikvörðum með samanburð við OECD lönd í huga. Framsetningin hér er kerfisbundin og styður um margt möguleika á slíkum samanburði. Leiðarljós Stefáns er aukning skattbyrði eins og pví hefur verið lýst hér en ályktanir hans af pví eru pó ekki pær sömu og hér. Stefán setur einnig skattlagningu launatekna í samhengi við aðra tekjuöflun og telur að lágir tekjuskattar fyrirtækja og lágur fjármagnstekjuskattur hér gangi á svig við hið norræna tvípætta kerfi tekjuskatts (e. dual income tax system) sem almennt skattleggi fjármagn og vinnuafl með sömu grunnprósentu en skattleggi svo vinnuaflið í ríkari mæli með auknum tekjum. Sjá t.d. Boadway (2004) par sem er að finna lýsingu á tvípættu kerfi tekjuskatts. Pá er að finna frekari greiningu í Stefáni Ólafssyni og Arnaldi Sölva Kristjánssyni (2012). Önnur sjónarmið öndverð peim sem Stefán setur fram má meðal annars finna í Hannesi H. Gissurarsyni (2007). Axel Hall (2015) fjallar ennfremur um pessa próun og setur í samhengi við Norðurlöndin.

Hér verður próuninni lýst án pess að leitast við að leggja dóm á pá pólitísku vegferð sem hefur verið farin eða vangaveltur um aðrar leiðir mögulegar hingað til. Rauði práðurinn 
hefur verið próun skattleysismarka. Í norrænum samanburði kemur fram að pau teljast há og fyrsta prósentan líka. Í pessu samhengi skiptir jafnframt máli að ekki hefur gengið að lækka grunnprósentuna á öllu tímabilinu sem neinu nemur. Рað telst óheppilegt hvað skilvirkni varðar í ljósi framboðsáhrifa kerfisins á hvata til vinnu. Kerfið hefur einkennst af pví að hafa fá prep og vægi skattleysismarka til jöfnunar hefur verið mikið. Að vísu hefur dregið úr vægi skattleysismarkanna og jöfnunin hefur par af leiðandi minnkað.

Kerfi með framangreindri próun parf að endurstilla reglulega standi vilji til að viðhalda lóðréttri jöfnun í kerfinu. Раð kallar á stefnumótun um prep (stig og fjölda), mörk prepa (t.a.m. skattleysismörk) og próun markanna yfir tíma. Pörfin fyrir virka hagstjórn verður áfram fyrir hendi og mikilvægt að huga að stefnumörkun um hvernig prepamörk eigi að próast yfir tíma.

Í pessari grein er farið yfir pá valkosti sem stjórnvöld hafa sett fram varðandi breytingar á skattkerfinu og niðurstaða peirrar stefnumörkunar greind með áhrifum á jöfnun í kerfi tekjuskatts.

\section{Tæknilegir pættir}

pegar hugað er að próun kerfis tekjuskatts yfir tíma og að samanburði við önnur lönd parf að setja fram hugtök og aðferðafræði við samanburðinn, enda skattkerfin sjálf breytingum háð í einstökum löndum yfir tíma og ólík yfir lönd.

Í skýrslum OECD eru reiknaðir jaðarskattur launpega, heildarjaðarskattur launpega og launagreiðanda, skattbyrði (meðalskattur) launpega og skattbyrði launpega og launagreiðanda saman. Pessir mælikvarðar byggjast á pví á hvern skatturinn er lagður, p.e. á launpegann eða launagreiðandann. Mikilvægt er að átta sig á pessum hugtökum og pví er hér sett niður nákvæm skýring á peim. Ólíkir jaðar- og meðalskattar eru sérlega mikilvægir við úttekt skattkerfa par sem sá aðili sem innir skattinn af hendi ber ekki endilega byrðina sem af honum hlýst. Hvernig skattbyrðinni er deilt ræðst af viðbrögðum launafólks og vinnuveitenda. Háir skattar á launpega eru líklegir til að hafa í för með sér hærri launakröfur peirra og hærri skattar á launagreiðendur draga úr getu peirra til að greiða launpegum há laun. Skattbyrðinni er pví deilt og niðurstaðan í pví ferli ræðst af viðbrögðum á markaði við launabreytingum. Heildarjaðarskattur og heildarskattbyrði eru pví peir mælikvarðar sem málefnalegt er að notast við í samanburði skatta.

Annað sem vert er að benda á áður en samanburðurinn er skoðaður eru framlög í lífeyrissjóði. OECD tekur ekki tillit til peirra enda eru skattar almennt skilgreindir sem greiðsla til hins opinbera án pess að skilgreint endurgjald komi fyrir. Lífeyrisgreiðslur uppfylla ekki pá skilgreiningu. Engu að síður reiknar OECD til viðbótar við framangreint svokallaðan skyldufleyg (e. compulsory payment wedge). Í honum eru allar lögbundnar skyldugreiðslur sem aðilar á vinnumarkaði standa frammi fyrir. Par birtast áhrifin hérlendis af skylduframlagi í lífeyrissjóð en ekki annars staðar á Norðurlöndunum enda eru framlögin par niðurstaða heildstæðra eða sérkjarasamninga á vinnumarkaði en ekki lögbundin. ${ }^{2}$ Skyldufleygur er ekki settur fram hér.

Hugtökin sem parfnast hér umfjöllunar eru meðal- og jaðarskattar bæði til að fastsetja hugtökin og að búa til viðmið og aðferðafræði. Jaðarskattar gefa til kynna hversu mikið skattskylda vex við viðbótareiningu tekna. Meðalskattar gefa til kynna pann hluta heildartekna (brúttótekna) sem fer til greiðslu tekjuskatts (OECD, 2011). Pessa tvo mælikvarða, meðalskattur og jaðarskattur er hægt að nota til að mæla stigmögnun skattkerfis p.e. hversu prógressíft kerfið er. Samanburð sem hægt er að beita innan lands yfir tíma og milli landa. Hér er stigmögnun almennt í skattkerfi skilgreind sem breytingar á prósentustigi skattlagningar eftir pví sem tekjustig eða skattprepum fjölgar. ${ }^{3}$

Mikilvægt er að gæta nákvæmni í pessu samhengi. Jakobsson (1976) bendir á að venjulega er litið svo á að stigmögnun í skattkerfi eigi að skilgreina sem kerfi par sem meðal-

2 Sjá OECD „Taxing Wages“ (2009).

3 http://www.encyclopedia.com/topic/Progressive_Tax.aspx. 
skattur vex með auknum tekjum fyrir skatt. Í pessu felast jöfnunareiginleikar skattkerfis. Hann bendir að stig jöfnunarinnar sé oft túlkað á ólíkan hátt af stjórnmálamönnum og hagfræðingum og sitt sýnist hverjum. Musgrave og Tun Thin (1948), lögðu til mismunandi mælikvarða á stigmögnun. ${ }^{4}$

Nytsamlegur mælikvarði sem er óháður hvers konar skattkerfi á í hlut er teygni ráðstöfunartekna með tilliti til heildarlauna (e. residual income progression). Mælikvarði sem sýnir prósentubreytingu ráðstöfunartekna við 1\% breytingu heildartekna (frá gefnu tekjustigi) er tölulegur mælikvarði sem tekur mið af skattkerfinu og leyfir einfaldan samanburð milli kerfa.

Hér táknum við $w_{e}$ sem heildarlaunatekjur einstaklings $e$, eftir skatt ${ }^{5}$ (e. net wage income) og $w$ sem launatekjur einstaklings fyrir skatt (e. gross wage income) og $T_{e}(w)$ eru skattar greiddir af einstaklingi sem fall af heildarlaunatekjum hans. Sama á við um launagreiðanda par sem neðanmálsgreinin $f$ vísar til fyrirtækis; $w_{f}$ táknar heildarlaun til launpega og skatta greidda af launagreiðanda oft kallað laun og launatengd gjöld. ${ }^{6}$ Petta gefur tvær jöfnur sem lýsa skattfleyg sem fyrirtæki og launafólk stendur frammi vegna einstaks framteljanda, ${ }^{7}$

$$
w_{e}=w-T_{e}(w)
$$

og

$$
w_{f}=w+T_{f}(w) \text {. }
$$

Pessar jöfnur sýna að mismunandi er hvernig jaðar- og meðalskattar launafólks og launagreiðanda eru eftir pví hvor er innheimtur. Jaðarskattur launpegans er pá $T_{e}^{\prime}(w)$ og meðalskatturinn er $T_{e}(w) / w$. Fyrir launagreiðandann er jaðarskatturinn $T_{f}^{\prime}(w)$ og meðalskatturinn er $T_{f}(w) / w_{f}$.

Teygni launpega og vinnuveitanda sem mælir áhrif hækkunar launa á ráðstöfunartekjur launpegans annars vegar og launakostnað launagreiðanda hins vegar má búa til útfrá almennri skilgreiningu á teygni, p.e. diffurkvóta falls deilt með meðalfalli pess. Мeð pví að beita pessari skilgreiningu á launafall launpegans fæst:

$$
\eta_{e}=\frac{\frac{d w_{e}}{d w}}{w_{e} / w}=\frac{\left(1-T_{e}^{\prime}(w)\right)}{\left(1-T_{e} / w\right)},
$$

sem mælir hversu mikið ráðstöfunartekjur breytast í prósentum við 1\% aukningu tekna launpega fyrir skatt (e. residual income progression) við gefið tekjustig eins og Jakobsson (1976) skilgreinir pað, hér nefnt teygnistuðull jöfnunar ráðstöfunartekna. Í kerfi sem ekki er regressíft og jaðarskattar eru lægri en 100\% gefur mælikvarðinn til kynna vöxt ráðstöfunartekna með auknum tekjum og par með stigmögnun skattkerfis eftir pví sem launpeginn fær hlutfallslega minna í sinn hlut og teygnin verður lægri. Mælikvarðinn felur í sér samanburð á jaðarskatti og meðalskatti og mælir hlutfallslega muninn parna á milli. ${ }^{8}$ Teygnin er á bilinu 0 til 1 par sem 1 svarar til að skatturinn sé flatur. Peim mun lægri sem hún er pví hærri er jaðarskatturinn í samanburði við meðalskattinn og peim mun meiri er jöfnunin:

4 Average rate progression (the derivative of the tax rate with respect to income before tax); marginal rate progression (the derivative of the marginal tax rate with respect to income before tax); liability progression (elasticity of tax liability with respect to income before tax); residual income progression (elasticity of income after tax with respect to income before tax).

5 Hér er um að laun eftir skatt en fyrir skylduframlag launpega í lífeyrissjóð miðað við íslenska kerfið.

6 Staðli OECD Taxing Wages er hér beitt og ekki gert ráð fyrir lífeyrissjóðsframlagi launagreiðanda.

7 Framsetning Cahuc og Zylberberg (2004) er notuð.

8 Hér er vert að hafa í huga diffurkvóta falls og meðalfalls p.e. $f^{\prime}(x)$ og $f(x) / x$. Eftir pví sem diffurkvótinn (jákvæður) er stærri en meðalfallið togar hann meðfallið hraðar upp. İ pví samhengi pýðir pað að eftir pví sem jaðarskattur er hærri en meðalskattur hækkar meðalskatturinn hraðar og par með skattbyrðin með auknum tekjum - jöfnunaráhrifin verða meiri. 


$$
T_{e}^{\prime}(w)>T_{e} / w=>\eta_{e}<1
$$

Á svipaðan hátt má draga fram teygni launakostnaðar á móti heildarlaunum launpega

$$
\eta_{f}=\frac{\frac{d w_{f}}{d w}}{w_{f} / w}=\frac{\left(1+T_{f}^{\prime}(w)\right)}{\left(1+T_{f} / w\right)},
$$

Í kerfi sem ekki er regressíft mun meiri stigmögnun leiða til pess að teygnin verður hærri en einn.

$$
T_{f}^{\prime}(w)>T_{f} / w=>\eta_{f}>1 .
$$

Annar mælikvarði sem nýtist hér er að taka hlutfall hinna tveggja ofangreindra mælikvarða

$$
\psi=\frac{\eta_{e}}{\eta_{f}}
$$

sem er peim mun lægri peim mun meiri stigmögnunin er í skattkerfinu. Pessi mælikvarði hefur pann kost að taka tillit til skattheimtu á launagreiðanda og launpega og mælir hlutfallslega aukningu ráðstöfunartekna pegar launakostnaður (launagreiðanda) vex um 1\%. Pessi mælikvarði er teygnistuðull jöfnunar ráðstöfunartekna launpega í launakostnaði launagreiðanda. Mælikvarðinn verður ekki nýttur frekar en vísað til hans pegar lagður er fram annar jafngildur mælikvarði.

Skattbyrði er óháð hvorum megin skattlagning á sér stað líkt og áður hefur komið fram. Jaðar- og meðalskattar sem mæla heildar jaðar- og meðalskatta eru pví viðeigandi fyrir alla skattagreiningu. Hingað til hefur verið hugað að launpega og launagreiðandi aðgreint og skattfleygur hvors um sig greindur. Í tilfelli fyrirtækisins var pað mismunur $w$ og $w_{f}$ og hjá launpega $w_{e}$ og $w$. Heildarskattfleygurinn verður pví mismunur $w_{f}$ og $w_{e}$. Héðan í frá pegar hugað er að heildarskattfleyg taka föllin mið af $w_{f}$ í stað $w$. Frá pessu sjónarhorni, skilgreinum við heildarmeðalskatt á vinnuafl sem launagreiðendur og launpegar standa saman frammi fyrir sem hlutfall heildarskatta $T$ (summa skatta á launagreiðendur og launpega) og heildarlaunakostnaðar $w_{f}$ Petta er pað sem OECD „,Taxing wages” vísar til sem meðalskattafleygur (e. average tax payment wedge).

$$
\bar{T}=\frac{T_{e}(w)+T_{f}(w)}{W_{f}} .
$$

Jaðarskattar hér mæla pví heildarskatta pegar heildarlaunakostnaður (laun og launatengd gjöld) vex um eina einingu, p.e. afleiðan af $T$ með tilliti til $w_{f}$ Pá verður að taka tillit til pess að heildarlaunakostnaður launagreiðanda eykur laun launpegans $w$, sem eru pær launatekjur sem eru undirstaða álagningar skattyfirvalda. Pessi tengsl nást fram með keðjureglu diffrunar og gefur okkur jöfnu jaðarskatts frá peim skattaföllum sem nú pegar hafa verið kynnt til sögu. Pessi mælikvarði kallast skv. OECD Taxing Wages aðferðafræðinni jaðarskattafleygur (e.the marginal tax payment wedge).

$$
T^{\prime}\left(w_{f}\right)=\frac{d T}{d w_{f}}=\frac{d T}{d w} \cdot \frac{d w}{d w_{f}}=\frac{\frac{d T}{d w}}{\frac{d w_{f}}{d w}}=\frac{T_{e}^{\prime}(w)+T_{f}^{\prime}(w)}{1+T_{f}^{\prime}(w)} .
$$

Að lokum er hér settur fram nýr teygnimælikvarði sem tekur hlutfallið milli heildarjaðarog meðalskatts launpega og launagreiðanda: 


$$
\Omega=\frac{\text { Jaðarskattur }}{\text { Meðalskattur }}=\frac{\frac{d T}{d w_{f}}}{\frac{T}{W_{f}}} .
$$

Pessi mælikvarði lýsir prósentubreytingu heildarskatts ef heildarlaunakostnaður vex um eitt prósent og gefur sama innsæi og $\psi$ sem var fyrir ráðstöfunartekjur. Petta er pað sem Musgrave og Tun Thin (1948) vísa til sem stigmögnun skuldbindingar (e. liability progression). Peir setja pennan mælikvarða ekki fram fyrir launpega og launagreiðanda saman líkt og gert er hér. Ef aukning skattgreiðslna er meira en eitt prósent verður mælikvarðinn stærri en einn og stigmögnun er til staðar. Ef skattar eru stigminnkandi verður mælikvarðinn minni en einn og ef skattar eru hlutfallslegir pá er mælikvarðinn einn. Petta er yfirgripsmesti mælikvarðinn á stigmögnun og hefur pann kost að passa við gögn sem eru til reiðu í OECD Taxing Wages gagnagrunni par sem reiknaður er heildarjaðarskattur og heildarmeðalskattur.

Í allri pessari umfjöllun verður að hafa í huga að skattar breyta pví hvað launpegar fá í sinni hlut af hverri viðbótarkrónu sem tekjur peirra aukast. Jaðarskattur hefur pví áhrif á pann hvata sem einstaklingurinn stendur frammi fyrir áður en tekin er ákvörðun um aukið vinnuframlag. Nettóávinningur af viðbótarvinnustund endurspeglar hvatann sem einstaklingurinn stendur frammi fyrir. Hækkun jaðarskatts lækkar nettóávinning að öðru óbreyttu. Pegar horft er til viðbragða aðila við skattlagningu er fræðilega lítið hægt að segja um viðbrögð einstaklinga við tekjuskattsbreytingum par sem tvenns konar öfl togast á: Tekjuáhrif skattbreytingar sem leiða til aukins vinnuframboðs einstaklinga annars vegar og svo tilfærsluáhrifin hins vegar sem draga úr vinnuframboði peirra. Hagrannsóknir gefa ekki skýr svör um petta. Norðurlandapjóðirnar til að mynda vinna ekkert minna en aðrar pjóðir prátt fyrir háa skatta. Sjá t.d. Axel Hall (2015), Axel Hall og Gylfa Zoega (2015) og Barth o.fl. (2014). Pá sýna rannsóknir sem eru einskorðaðar við einstök lönd að viðbrögð við skattabreytingum fara mjög eftir pví hvaða tekju-, aldurs- og pjóðfélagshóp framteljandinn tilheyrir sjá t.d. Blundell og MaCurdy (1999). Pað er pví óljóst hversu mikil fórnarskipti eru milli áhrifa skattlagningar á skilvirkni í efnahagslífinu og jafnaðar.

Мeð peim skilgreiningum, fallformum og greiningartækjum sem hér hafa verið sett fram er nú hægt að líta á íslenska skattkerfið og greina jaðarskatta, meðalskatta og stigmögnun í pví kerfi og próun pess yfir tíma.

\section{Staðgreiðslan frá 1988}

Hér á eftir fer lýsing á kerfi tekjuskatts á Íslandi og próun pess yfir tíma. Ýmsar mis viðamiklar opinberar úttektir hafa verið gerðar á íslenska tekjuskattkerfinu frá pví að staðgreiðslan var tekin upp árið 1988. Prjár peirra viðamestu eru frá árunum 1997, 2008 og 2015 og eru pær allar verðmætar heimildir um pað hver viðfangsefnin og áherslur hafa verið og par af leiðandi mikilvægur grunnur. Fjármálaráðuneytið (1997), Friðrik M. Baldursson (2008), Axel Hall (doktorsritgerð, 2015) og Alpjóðagjaldeyrissjóðurinn (2015). Auk peirra hefur hér verið leitað víðar fanga í peirri viðleitni að lýsa eðli kerfisins og próun pess sem gleggst. Tekjuöflun ríkisins í formi tekjuskatts á einstaklinga er eitt peirra álitamála sem varðar alla pegna pjóðfélagsins, jafnt einstaklinga sem fjölskyldur, og er pví í eðli sínu stórpólitískt viðfangsefni sem snertir sjónarmið um skilvirkni og jöfnuð.

Almennt er prenns konar aðferðum nú beitt við að skattleggja tekjur einstaklinga. Í fyrsta lagi er beitt hefðbundnu yfirgripsmiklu skattkerfi par sem allar tekjur einstaklinga eru lagðar saman og skattlagðar í einu lagi (e. Comprehensive Income Tax System). Í öðru lagi er beitt tvöföldu skattkerfi par sem stighækkandi hlutfallslegur skattur er greiddur af launatekjum en lágur, flatur skattur af fjármagnstekjum. Í priðja lagi er síðan um að ræða einhvers konar blöndu af hinum leiðunum tveimur par sem hluti fjármagnstekna er skatt- 
lagður hlutfallslega lægra, vextir og söluhagnaður. Ísland, Svípjóð, Noregur og Finnland hafa leitast við að fylgja priðju leiðinni; Danmörk einnig en pó með meiri stighækkun fjármagnstekna.

Pegar grunnprósenta fjármagnstekna, launatekna og skatts á hagnað lögaðila er hin sama er talað um hreint tvípætt skattkerfi (e. Pure Dual Income Tax System). hreint tvípætt skattkerfi felur í sér að helstu tekjuflokkar (atvinnu-, fjármagns-, lífeyristekjur og fyrirtækjahagnaður) bera álíka grunnprósentu. Síðan bætist við viðbótarálagsprep (skattprep) með hækkandi atvinnutekjum. Peir tekjuhærri í atvinnutekjum greiða pví hlutfallslega meira af tekjum sínum í opinber gjöld en hinir tekjulægri. Pegar grunnprósentur eru ólíkar er talað um hálftvípætt (e. Semi - Dual Income Tax System). ${ }^{9}$ Samkvæmt pessu er íslenska kerfið hálftvípætt pví að hér er grunnprósenta atvinnutekna hærri en grunnprósenta fjármagnstekna.

\subsection{Staðgreiðslukerfi atvinnutekna}

Núverandi kerfi tekjuskatts byggist á pví að eitt viðbótarálagsprep (efra skattprep) leggst ofan á grunnprep (neðra skattprep). Launafólk yfir 16 ára aldri á síðan rétt á fastri krónutölu í skattafrádrátt (persónuafslátt) sem dreginn er frá útreiknuðum tekjuskatti og útsvari. Pess utan eru iðgjöld í skyldubundna lífeyrissjóði og séreignarlífeyrissjóði upp að ákveðnu marki frádráttarbær frá tekjuskatti, sem veitir skattfrestun fram að útgreiðslu.

Helstu viðmið kerfisins fyrir tekjuárið 2018 eru eftirfarandi: ${ }^{10}$

- Skatthlutfall í neðra prepi, staðgreiðsla: $36,94 \%$, p.a. tekjuskattur 22,5\% og meðalútsvar $14,44 \%$.

- Skatthlutfall í efra prepi, staðgreiðsla: $46,24 \%$, p.a. tekjuskattur 31,8\% og meðalútsvar 14,44\%.

- Persónuafsláttur: 53.895 kr. á mánuði, eða 646.740 kr. á ári.

- Tekjumark efra preps: 893.713 kr. í skattskyldar tekjur á mánuði, eða 10.724 .556 kr. á ári.

- Skattleysismörk: 145.899 kr. í skattskyldar tekjur á mánuði; 151.978 kr. á mánuði miðað við frádrátt $4 \%$ lífeyrisiðgjalda.

Hér á eftir fer stærðfræðileg framsetning á skattkerfi atvinnutekna. Stikar kerfisins hafa tekið breytingum yfir tíma. Skattafallið hefur tengsl við framsetninguna eins og lýst var í jöfnu (1) í kaflanum á undan par sem ráđstöfunartekjur launpega voru reiknaðar. ${ }^{11}$

9 Fundamental Reform of Personal Income Tax OECD, (2006): „The dual income tax system levies a proportional tax rate on all net income (capital, wage and pension income less deductions) combined with progressive rates on gross labour and pension income. This implies that labour income is taxed at higher rates than capital income, and that the value of the tax allowances is independent of the income level.

The semi-dual income tax system uses different nominal tax rates on different types of income, typically by taxing some forms of capital (personal and corporate) income at low and often flat rates and remaining forms of income at higher and progressive rates."

10 Hér er almennt tekjuárið 2018 til viðmiðunar sem var grundvöllur álagningar 2019.

11 Í kaflanum hér að framan var talað um skatta sem fall af heildarlaunum launpega. Á Íslandi er hefðbundið að miðað sé við jaðar- og meðalskatt skattskyldra launa p.e.laun að frádregnu heimiluðu framlagi launpegans í lífeyrissjóð í skyldu- og séreignarframlagi og hér byggist pví umfjöllunin á pví. 


$$
\begin{aligned}
T_{e}(w) & \max \left(\left(\sum_{i=1}^{n} \Delta \tau_{i} \cdot \max \left(0,\left(w(1-p)-t_{i}\right)\right)\right)-c, 0\right) \\
\tau_{1}: & \text { Grunnprósenta } \\
\Delta \tau_{i}: & \text { Viðbótarprósenta fyrir prep } i, \Delta \tau_{1}=\tau_{1} \\
t_{i}: & \text { Neðri tekjumörk fyrir prep } i, t_{1}=0 \\
p: & \text { Hlutfallslegt framlag launpega í lífeyrissjóð } \\
c: & \text { Persónuafsláttur } \\
n: & \text { Fjöldi prepa } n=[1,3] .
\end{aligned}
$$

Við mat á skattkerfi sem pessu er meðal annars litið til skattbyrði, jaðarskatta og samspils pessara pátta. Skattbyrði, eða meðalskatthlutfall, vísar til hlutfalls greiddra skatta af skattskyldum tekjum eftir frádráttarliði frá skattstofni (t.d. lífeyrissjóðsiðgjöld) en jaðarskattur er pað hlutfall tekna sem framteljandi greiðir í tekjuskatt af hverri viðbótarkrónu sem hann aflar. Líkt og ádur hefur verið fjallað um.

Á mynd 1 sést hvernig skattbyrði og jaðarskattur próast með mánaðarlegum skattskyldum tekjum í núverandi kerfi tekjuskatts. Skattbyrði og jaðarskattur stendur í núlli par til skattleysismörkum er náð. Skattleysismörk eru pær tekjur par sem persónuafsláttur er fullnýttur á móti álögðum skatti og eru um leið mörk pess sem framteljandi byrjar að greiða skatt til hins opinbera. Pegar pessu viðmiði er náð stendur launpegi frammi fyrir 36,94\% jaðarskatti af launum w, par til mánaðartekjur viðkomandi ná tekjumarki efra preps. Tekjur umfram pað mark bera $46,24 \%$ jaðarskatt; par vex skattbyrðin hraðar en áður og pví myndast bugða í skattbyrðisferlinum við markið. Vert er að skýra lögun ferilsins nánar.

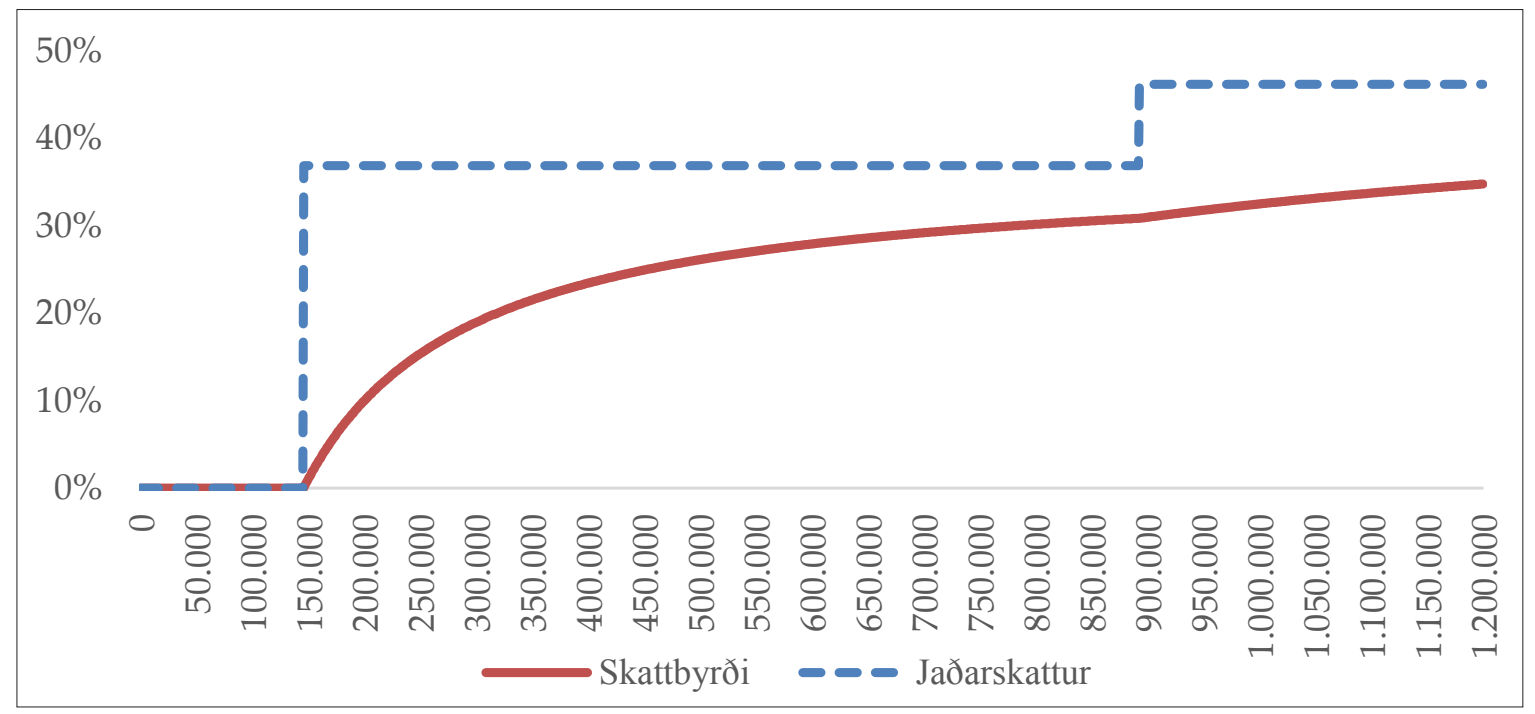

Mynd 1. Skattbyrði og jaðarskattur eftir mánaðarlegum skattskyldum tekjum 2018. ${ }^{12}$

Heimild: Ríkisskattstjóri og eigin útreikningar.

Frá skattleysismörkum að marki efra preps er skattbyrðin jöfn grunnprósentunni að frátöldum persónuafslætti deilt með skattskyldum tekjum, p.e.. ${ }^{13}$

12 Skattskyld laun eru heildarlaun launpegans að frátöldu heimiluðu framlagi hans í lífeyrissjóð p.e. $w(1-p)$.

13 Jafnan er fengin með pví að deila í greiddan skatt með skattskyldum tekjum. Umfjöllunin snýst um lögun skattbyrði í neðra prepi. Skattbyrði tekna yfir efra marki tekur mið af pví sem hér er sagt en til viðbótar leggjast áhrif álags í efra prepi sem eykur halla ferils að nýju. Hægt er að sýna að skattbyrði tekna yfir efra marki er skattprósentan í efra prepi að frátöldu broti sem hefur annars vegar persónuafslátt í teljara og hins 


$$
\text { Skattbyrði skattskyldra launa } \%=\frac{T_{e}(w)}{w(1-p)}=\left(\tau_{1}-\left(\frac{c}{w(1-p)}\right)\right)
$$

Ferill skattbyrði p.e. meðalskatturinn er hvelfdur í skattskyldum tekjum í hverju prepi og jaðarskatturinn myndar láfellu fyrir meðalskattinn eftir pví sem skattskyldar tekjur verða háar. ${ }^{14}$ Út frá pessari jöfnu sést að seinni liðurinn hefur mikið vægi pegar skattskyldar tekjur eru lágar en pað dregur hratt úr vægi hans með vaxandi tekjum. Skattbyrðin eykst að sama skapi og stefnir á að vera á pari við skattprósentuna sjálfa við háar tekjur pegar aftur á móti seinni liðurinn verður óverulegur. Seinni liðurinn mælir ívilnun skattbyrðar sem aðili með lágar tekjur fær og um leið jöfnunina sem felst í pví hvernig liðurinn minnkar við hærri tekjur sem leiðir til pess að skattbyrði nálgast skattprósentuna.

Ferillinn er brattur fyrst og verður síðan flatari eftir pví sem tekjurnar hækka par til að hann nálgast láréttan feril skattprósentu grunnpreps. Lögun ferilsins (sveigjan), p.e. hversu flatur eða brattur hann er við tilteknar tekjur, ræðst af persónuafslættinum. Staðsetning ferilsins á myndinni, p.e. hvort hann stendur ofarlega eða neðarlega, ræðst af stigi skattprósentu grunnpreps.

Pví brattari sem ferillinn er peim mun meiri eru jöfnunaráhrif skattkerfisins við pær tekjur. Jöfnunin sem brattinn á ferlinum í heild endurspeglar felur í sér pýðir að hinir tekjuhærri beri hlutfallslega meiri skattbyrði en peir tekjulægri en um leið vaxa byrðar peirra tekjulægri hlutfallslega hraðar með auknum tekjum en peirra sem njóta hærri tekna. Pegar ferill skattbyrði er skoðaður nánar sést hvernig skattbyrðin eykst mest við skattleysismörkin, en halli ferilsins fer síðan minnkandi eftir pví sem tekjur vaxa par til nýju og hærra skattprepi er náð en par myndast bugða í ferlinum og skattbyrði eykst hraðar en áður.

Jöfnun er í eðli sínu gildishlaðið viðfangsefni og pólitísk í eðli sínu. Um leið er jöfnunin ekki án kostnaðar pví að jaðarskattur hefur, eins og áður hefur verið nefnt, áhrif á pað hvort eða hve mikið einstaklingurinn leggur sig fram við tekjuöflun. Рað eru pví fórnarskipti milli jöfnunar og skilvirkni skattkerfisins. Af framansögðu má ráða að pegar viðmiðunarfjárhæðir og prósentur breytast á sér stað hliðrun á ferli skattbyrðarinnar og mikilvægt er að huga að eðli hinna mögulegu hliðrunarpátta. Áður hefur verið vikið að pví að skurðpunktur skattbyrðar við $x$-ás markist af skattleysismörkum. Pá hefur einnig komið fram að skattleysismörk ákvarðast af samspili persónuafsláttar og skattprósentu í neðra prepi með peim hætti að pau ákvarðast af pví tekjustigi par sem persónuafsláttur er fullnýttur. Tekjur umfram pau skattleysismörk bera síðan skattprósentu grunnpreps. ${ }^{15}$ Pessu sambandi má almennt lýsa með svofelldum hætti:

$$
A=\frac{c}{\tau_{1}} 16
$$

Hér skal nú hugað að áhrifum breytinga á persónuafslætti og skattprósentu grunnpreps á skattbyrði og pað hvernig ferillinn hliðrast og sveigja hans breytist eftir atvikum. Við hækkun persónuafsláttar lækkar skattbyrði allra og ferillinn færist niður en mismikið eftir tekjum og mest hjá peim sem lægstar tekjur hafa. Рað dregur úr áhrifunum með vaxandi tekjum og á endanum fjara áhrifin út pegar tekjur eru orðnar mjög háar. Færsla ferilsins niður á við (myndrænt er eins og hann hliðrist til hægri) gerir pað að verkum að hann sker $x$-ásinn seinna en áður enda hækka skattleysismörkin við hækkun persónuafsláttar. Ferillinn hefur ekki einungis færst niður, sveigja hans hefur breyst, ferillinn verður nú brattari og jöfnun vex (brotalínan). Atburðarásin verður öfug við lækkun persónuafsláttar.

vegar pann afslátt að greiða ekki viðbótarálagið af tekjum undir tekjumarki efra preps. Í pennan lið er svo deilt með skattskyldum tekjum.

14 Hægt er sýna fram á sveigju skattbyrðinnar með pví að reikna aðra afleiðu jöfnu (12) m.t.t. w(1-p) sem er 0 $>-2 c /(w(1-p))^{3}$.

15 Skattleysismörk launpega eru hærri en bótapega par sem síðarnefndi hópurinn greiðir ekki iðgjald í lífeyrissjóð. 


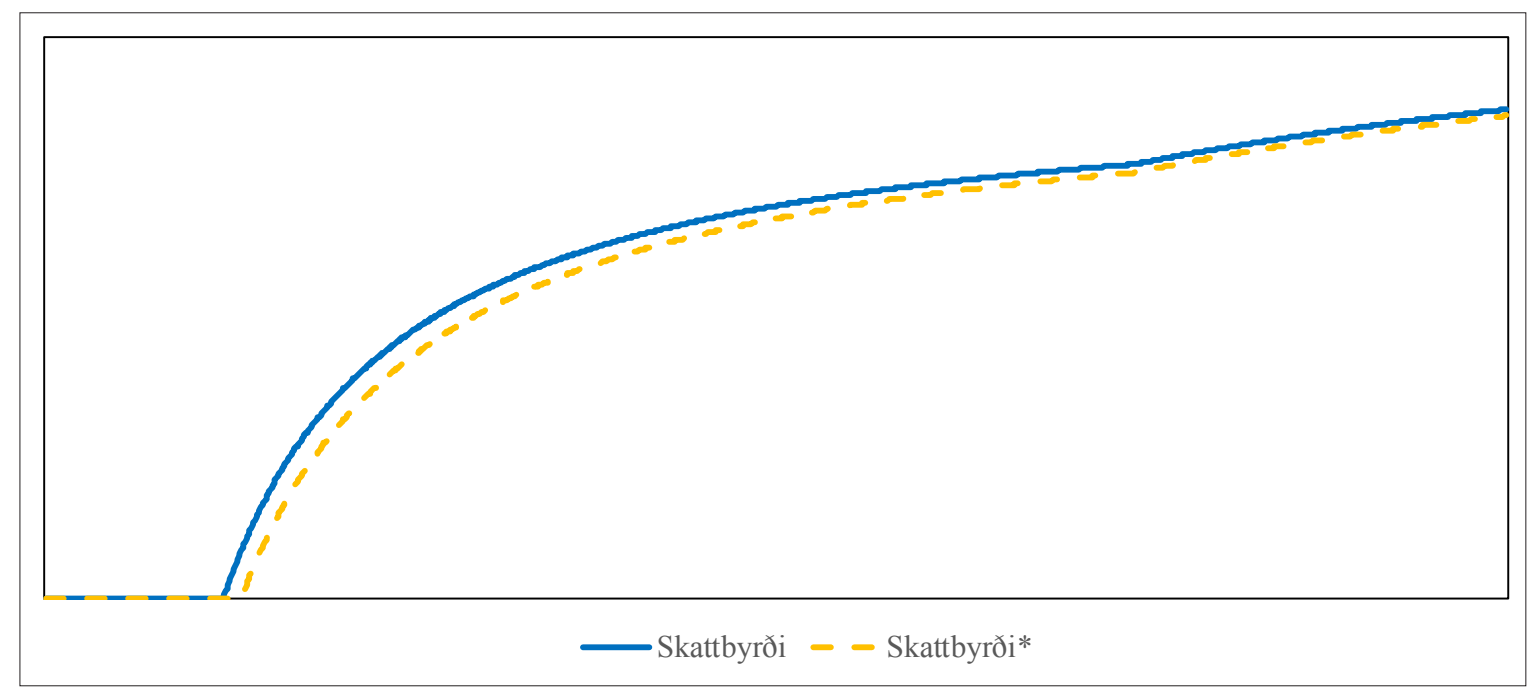

Mynd 2. Breyting á skattbyrði við hækkun persónuafsláttar.

Breyting skattprósentu grunnpreps hliðrar ferli skattbyrðar jafnt á öllum tekjustigum. ${ }^{16}$ Skattbyrðin kemur pví eins fram í breytingu hlutfallstölunnar fyrir alla og snertir par af leiðandi pá tekjuhærri með hærri krónutölu en pá sem eru tekjulægri. Ef skattprósenta í grunnprepi er lækkuð hliðrast ferillinn í heild sinni eins niður á við á öllum tekjustigum og skattleysismörkin aukast líka, p.e. skurðpunktur við $x$-ás hækkar (brotalínan). Sveigjan á ferlinum er óbreytt og vöxturinn í skattbyrðinni við hvert tekjustig er óbreyttur. ${ }^{17}$

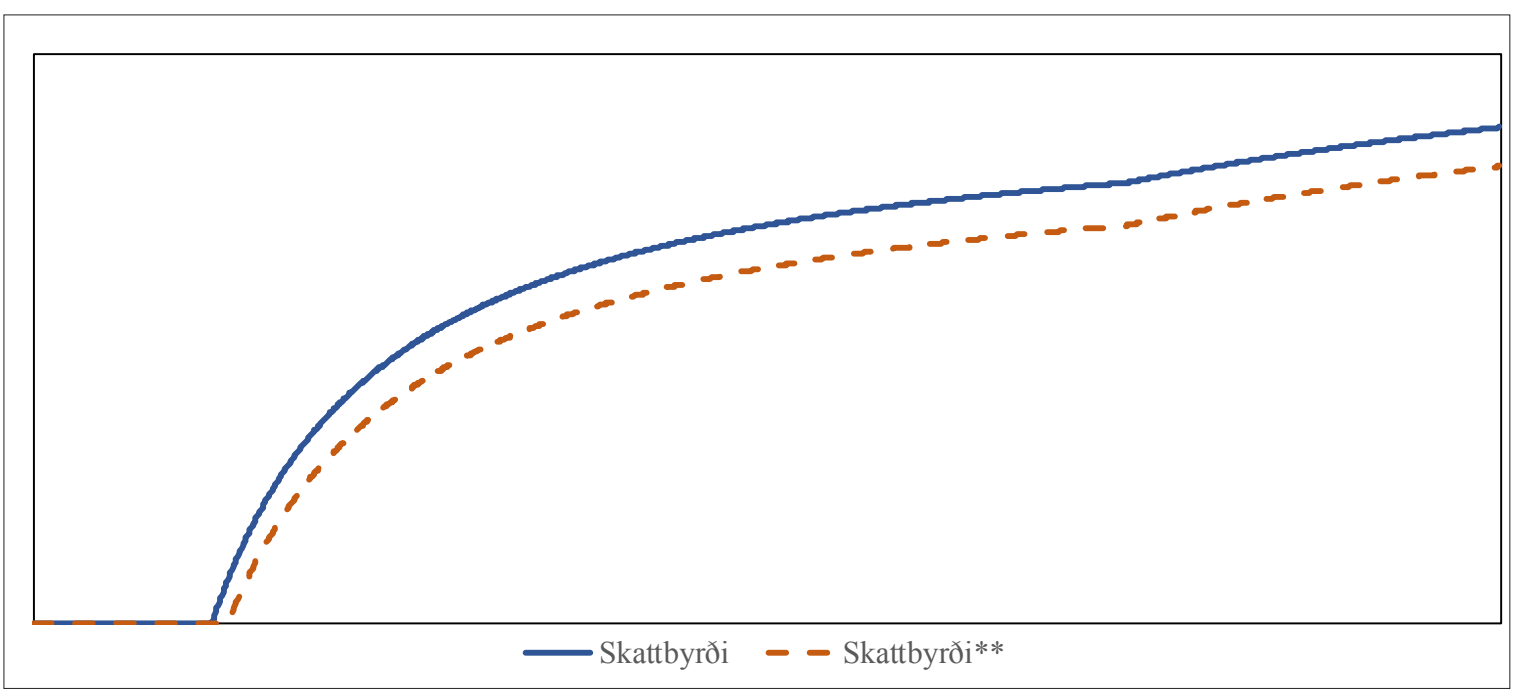

Mynd 3. Breyting skattbyrði við lækkun skattprósentu.

Framsetningin hér undirstrikar öll hversu villandi pað getur verið að einblína á persónuafslátt eða skattprósentu án samhengis, skoða verður samspil peirra. Við petta má bæta að skýrari samanburður fæst af pví að skoða skattleysismörkin og prósentu grunnpreps saman fremur en persónuafslátt og prósentuna. Persónuafslátt er ekki hægt að skoða án pess að taka tillit til pess hversu há skattprósentan er. Skattleysismörkin eru sama marki brennd; skoða verður prósentuna sem tekur við pegar skattleysismörkum sleppir. Á endanum er petta sín hvor hliðin á sama viðfangsefninu en á pví er pó ákveðinn blæbrigðamunur.

16 Svo framarlega að efra prepið sé grunnprósenta að viðbættu álagi en ekki sjálfstætt ákvarðað án tillits til grunnprósentu.

17 Petta má sjá með pví að diffra jöfnu 12 m.t.t. w(1-p). 
Pví til stuðnings má nefna að tekjuárið 2018 var persónuafsláttur 53.895 kr. á mánuði en skatthlutfall í neðra prepi eins og áður segir 36,94\%. Раð pýðir að skattleysismörkum var náð pegar 36,94\% af mánaðarlaunum námu 53.895 kr., p.e. við 145.899 kr. Pessi tilteknu skattleysismörk einskorðuðust pó ekki við pessi viðmiðunargildi. Væri persónuafsláttur t.d. lækkaður í 25 pús.kr. og skattprósentan í neðra prepi færð niður í 17,14\% myndu launpegar búa við sömu skattleysismörk. Munurinn á aðstæðum peirra væri hins vegar sá að jaðarskatturinn í grunnprepi væri mun lægri en áður og umskiptin pegar skattleysismörkum yrði náð færu pví mýkri höndum um skattgreiðendur en ella. Með öðrum orðum, jaðarskatturinn væri lægri. Á sama tíma væru jöfnunaráhrif kerfisins minni en áður um leið og hvati til vinnu hefði verið aukinn myndarlega. Ekkert skal fjölyrða um tekjuöflunina sem af slíkri ráðstöfun hlytist.

Hér var ferlinum hliðrað niður með lækkun prósentunnar sem hækkaði skattleysismörkin en hækkun skattleysismarkanna síðan dregin til baka með pví að lækka persónuafsláttinn sem gerði ferillinn flatari en áður. Framangreint sýnir að meira gagnsæi fæst með pví að skoða hvar greiðsla tekjuskatts hefst, p.e. skattleysismörkin, og hversu hárri skattprósentu greiðandi stendur pá frammi fyrir.

\subsection{Jöfnuður og staðgreiðsla}

Umfjöllunin um staðgreiðslukerfið hér að framan og stikana í pví kerfi gera okkur kleift að beita peim tólum sem kynntir voru til sögu í kafla 2 hér að framan p.e. jaðar-, meðalskattar og teygnistuðlar útfrá sjónarhóli launpega, launagreiðanda og aðilanna beggja saman. Með pví er unnt að mæla tölulega jöfnunaráhrifin í skattkerfinu.

Við lítum fyrst til launpegans og höfum í huga að miðað er við skattskyld laun w(1-p). Með pví að tvinna saman tæknilega umfjöllun 2. kafla og umfjöllun um staðgreiðslu í kafla 3.1 reynist einfalt að reikna jaðar- og meðalskatt pegar skattskyld laun eru hærri en skattleysismörkin $w(1-p)>A$. Í kjölfarið er einfalt að reikna teygnistuðul jöfnunar ráðstöfunartekna fyrir launpegann í fyrsta prepi.

$$
T_{e}^{\prime}(w(1-p))=\tau_{1}
$$

og

$$
\eta_{e}(w(1-p))=\frac{\left(1-\tau_{1}\right)}{\left(1-\tau_{1}+c / w(1-p)\right)}<1 .
$$

Раð er einfalt að sjá að eftir pví sem persónuafsláttur $c$ er hærri verður teygnin lægri (að pví gefnu að prósentan sé lægri en 100\%) og jöfnunin meiri en pað er líka hægt að reikna pað út að peim mun hærri sem prósentan, $\tau_{1}$ er pví lægri verður teygnin og jöfnunin meiri. Petta byggist á pví að pegar skattprósenta hækkar pá lækkar teljarinn (pað sem verður eftir af viðbótarkrónu) hlutfallslega meira en nefnarinn (meðalhlutfall eftir skatt), brotið lækkar og jöfnunin eykst samkvæmt pessum mælikvarða. Fyrir einstæðing án barna er teygnin eftirfarandi fyrir ólíkar skattskyldar mánaðartekjur 2018. Ferill sýnir hve mikil jöfnunin er fyrst eftir skattleysismörk en síðan dregur úr vægi jöfnunar en hún eykst aftur við efra tekjumarkið. Tekjur eru eftir framlag í lífeyrissjóð p.e. skattskyldar tekjur. 


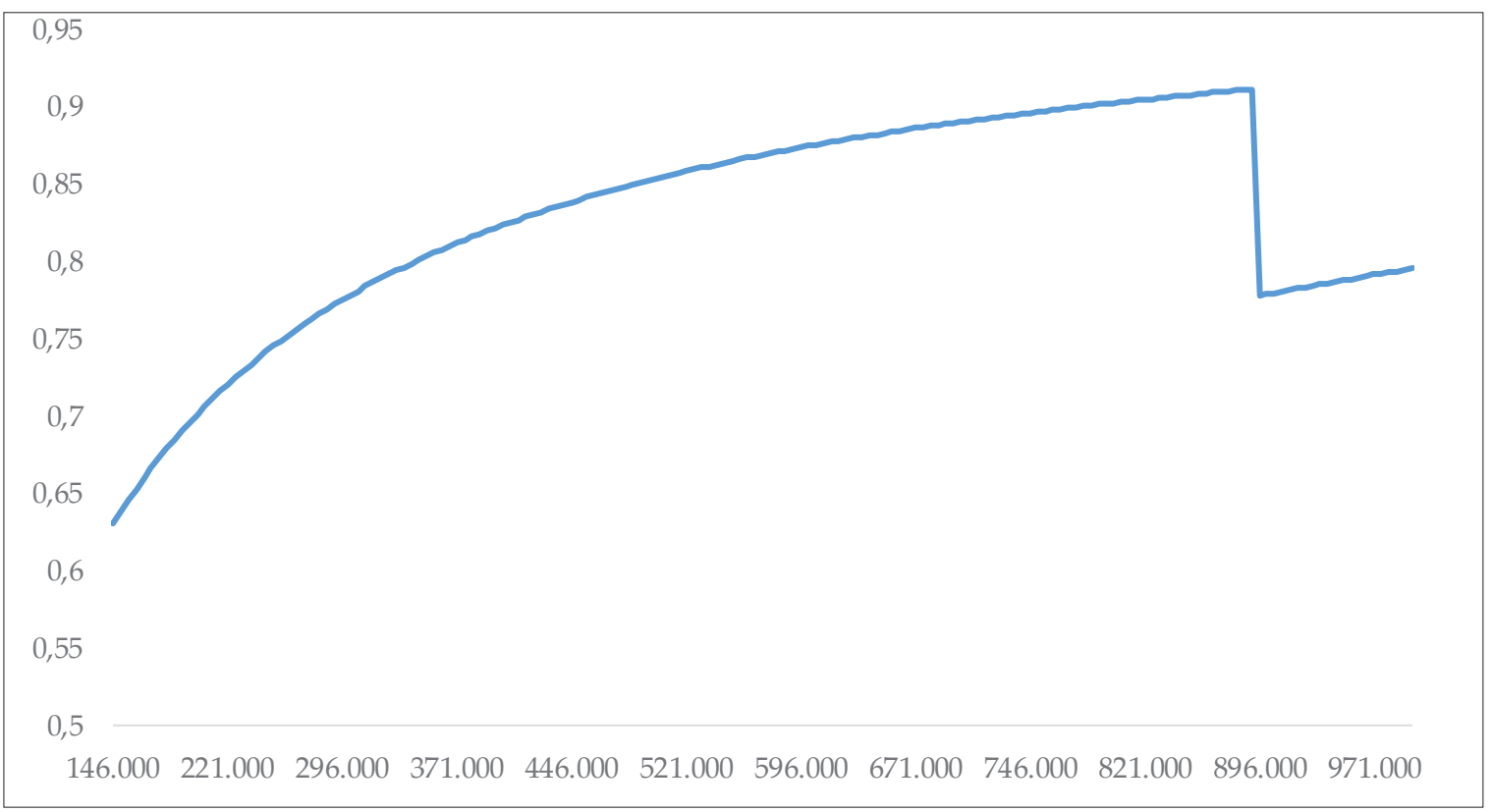

Mynd 4. Teygnistuðull jöfnunar ráðstöfunartekna og mánaðartekjur skattskyldra tekna $w(1-p)$ fyrir einstæðing án barna (2018)

Heimild: Ríkisskattstjóri og eigin útreikningar.

Pegar rætt er um jöfnunaráhrif skattkerfisins verður að setja pað í samhengi við tekjudreifinguna fyrir skatt. Mynd 5 sýnir samhengi skattskyldra tekna og skattbyrði á hægri ás og tekna og fjölda á tekjubilum á vinstri ás miðað við álagningu 2018 fyrir 25-65 ára með og án örorku. Samanburður á myndum 4 og 5 sýnir t.d. að par sem ferillinn að ofan er brattastur og jöfnunin par af leiðandi mest er að hafa áhrif á mjög marga.

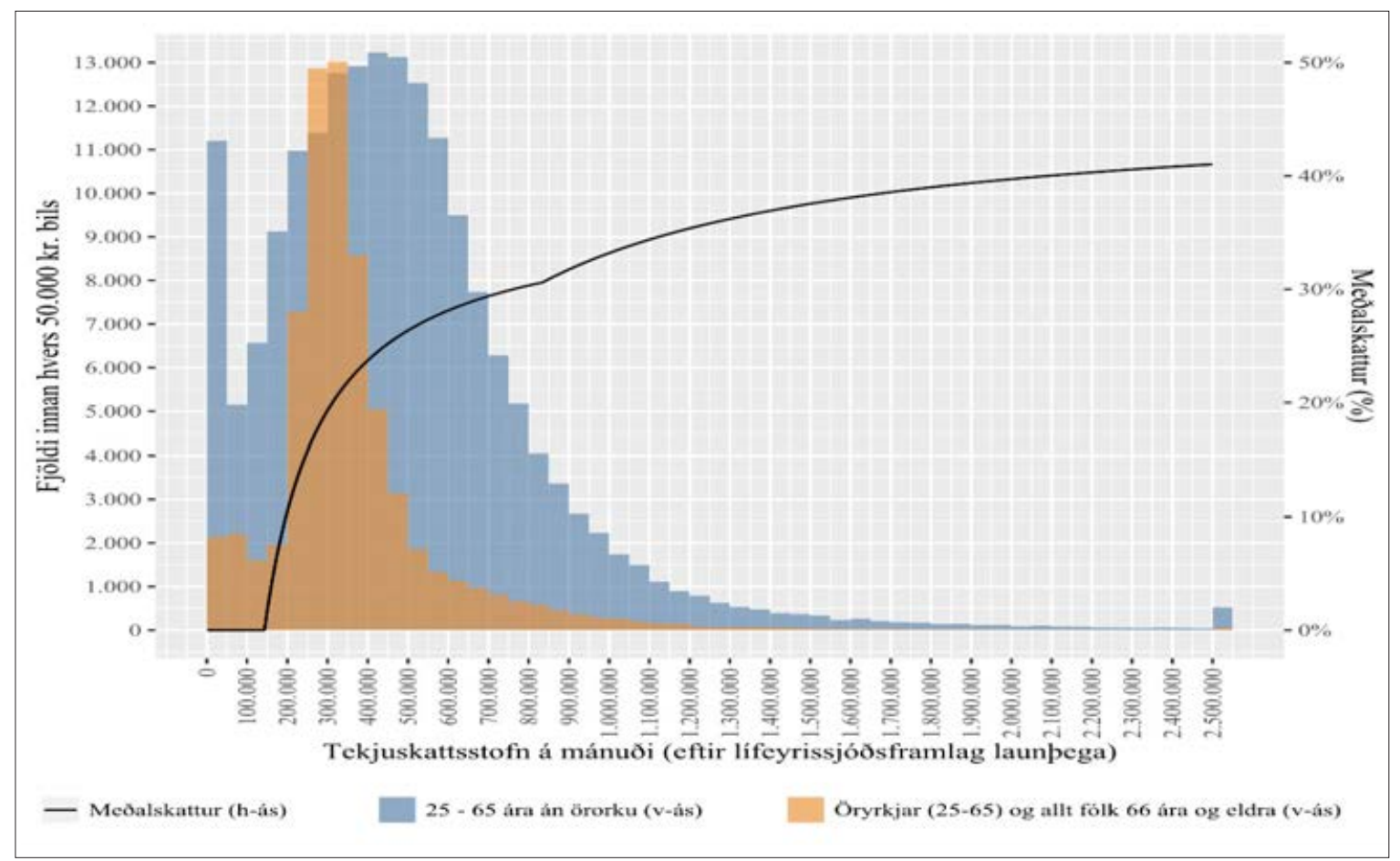

Mynd 5. Skattbyrði og tekjudreifingar við álagningu 2018.

Heimild: Fjármála- og efnahagsráðuneytið. 
Pessi greining vísar til skatta á launpegann. Eins og áður hefur verið lýst er hægt að taka tillit til skatta á launagreiðandann til viðbótar og greina heildarjaðarskatt og heildarmeðalskatt. Tryggingargjald 2018 var 6,85\% á laun og launatengd gjöld en framlag í lífeyrissjóð telst til launatengdra gjalda. Hér er ekki gert ráð fyrir séreignasparnaði og framlög í lífeyrissjóð teljast ekki til skatta en tekið er tillit til að framlag launpega í lífeyrissjóð er undanpegið skatti og framlag launagreiðanda í lífeyrissjóð bætt við laun til grundvallar gjaldstofni tryggingagjalds. Skattfleygurinn verður pví stærri en áður, tekur tillit til launpega og launagreiðanda. Hér á eftir reiknum við heildarskattbyrði og heildarjaðarskatt.

$$
\begin{gathered}
\bar{T}=\frac{T_{e}(W)+T_{f}(W)}{W_{f}}=\frac{0,96 \cdot 0,3694 \cdot W+0,0685 \cdot 1,115 \cdot W-53.895}{1,0685 \cdot 1,115 \cdot W} \\
T^{\prime}\left(w_{f}\right)=\frac{0,96 \cdot 0,3694+0,0685 \cdot 1,115}{1,0685 \cdot 1,115} .
\end{gathered}
$$

Af hlutfalli ofangreindra jafna getum við reiknað $\Omega$ heildarskattteygnina í jöfnu (10) með tilliti til launa og launatengdra gjalda p.e. jafna (17) deilt með jöfnu (16). Teygnin er fall af mánaðarlegum launum launpegans $w$. Niðurstöðurnar fyrir neðra prepið frá skattleysismörkum launa (151.978 kr) að tekjumörkum efra preps (930.951kr.) er hægt að sjá á meðfylgjandi mynd. Teygnin verður 5,9 pegar laun launpegans fara rétt yfir skattleysismörk og minnkar svo stöðugt. ${ }^{18}$ Ef ekki væri fyrir efra prepið myndi ferillinn hafa láfellu við einn p.e. pegar laun og launatengd gjöld hækka um eitt prósent pá munu skattar launpega og launagreiðanda til samans líka vaxa um eitt prósent. Jöfnur (16) og (17) eiga við pegar laun eru hærri en skattleysismörk launa. Pegar launin eru fyrir neðan er persónuafsláttur jafn 0,96·0,3694·w og pannig detta fyrsti og síðasti liður í teljara út í jöfnu (16) (hámarkspersónuafsláttur er 53.895)). Fyrri liðurinn í teljara íjöfnu (17) dettur einnig út og hlutfallið milli (17) deilt með jöfnu (16) verður einn. Allir skattar eru hlutfallslegir par til skattleysismörkum er nád. ${ }^{19}$

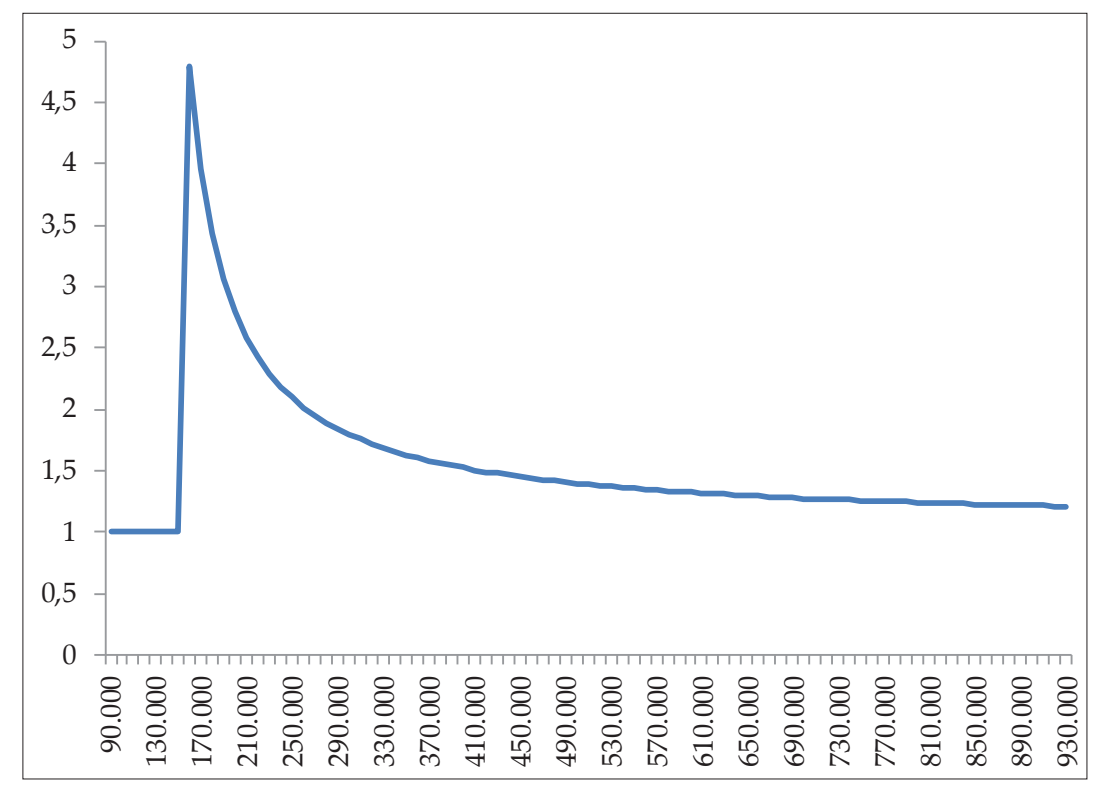

Mynd 6. Heildarskattteygni $\Omega$ fyrir mánaðartekjur einstaklings, $w 2018$ að efra prepi. ${ }^{20}$

18 Ástæða pess að ferillinn sýnir gildið fimm við skattleysismörk fyrir framlag í lífeyrissjóð (151.977) er að hann er reiknaður á bilum og skattleysismörkum er lítillega náð í útreikningi bilsins (160.000) á myndinni og teygnin lækkar hratt.

19 Hér er ekki tekið tillit til útvarpsgjalds eða framlag í framkvæmdasjóð aldraðra.

20 OECD (2011) skilgreinir svokallaðan skyldufleyg (e. Compulsory payment wedge) líkt og áður hefur verið 


\subsection{Raunskattskrið og sjálfvirk sveiflujöfnun}

Fjallað hefur verið um hvernig viðmiðunarfjárhæðir skattkerfisins (persónuafsláttur og efra tekjumark) verka á skattbyrði í kerfi á hverjum tíma pegar aðrar stærðir efnahagslífsins eru fastar. Efnahagslífið er í eðli sínu kvikt og á sífelldri hreyfingu yfir tíma. Laun og verðlag pokast almennt upp á við eftir pví sem tímanum líður. Pegar laun hækka eykst skattbyrðin ef viðmiðunarfjárhæðir skattkerfisins standa í stað. Рað sést best með pví að skoða jöfnuna fyrir skattbyrði par sem hækkun tekna án pess að persónuafsláttur hækki minnkar seinni lið jöfnunnar og skattbyrði eykst. Fylgi viðmiðunarfjárhæðir ekki eftir próun launa eykst skattbyrðin sjálfkrafa. Ef próun persónuafsláttar er tengd verðlagi eins og lögbundið er nú og laun hækka hraðar gerist pað sama fyrir seinni lið jöfnunnar (frádráttarliðinn), hann lækkar (minna en áður) og skattbyrðin eykst.

Áhrifum af tengingu persónuafsláttar við verðlag má lýsa myndrænt með hliðrun ferils skattbyrðar til hægri. Hliðrunin er pá knúin af hækkun persónuafsláttar og pá um leið hækka skattleysismörkin. Pegar hliðrunin heldur ekki í við hækkun kauplags (færslu framteljenda til hægri á $x$-ás) munu hinar hækkuðu tekjur í heild bera hærri skatt. Framteljandi færist pá upp brattann á hinum nýja ferli skattbyrðar í samanburði við fyrri stöðu. Pessi breyting skattbyrði er kölluð raunskattskrið (e. real fiscal drag). Eftir pví sem tekjur eru lægri verður vöxtur skattbyrði meiri par eð viðkomandi framteljendur eru í skattbyrði staðsettir á brattari hluta ferilsins (meiri jöfnun) en ólíkt peim sem hærri tekjur hafa par sem ferillinn er flatari hjá peim en skattbyrðin um leið pyngri. Pau áhrif að framteljendur með lægri tekjur verði fyrir meiri áhrifum af pyngri skattbyrði verða sterkari eftir pví sem prepin eru færri (ef pau hækkuðu um verðlag) og skattleysismörkin eru hærri. Pá pjóna skattleysismörkin stærra hlutverki við jöfnunina og áhrifin leggjast ekki eins á framteljendur. ${ }^{21}$

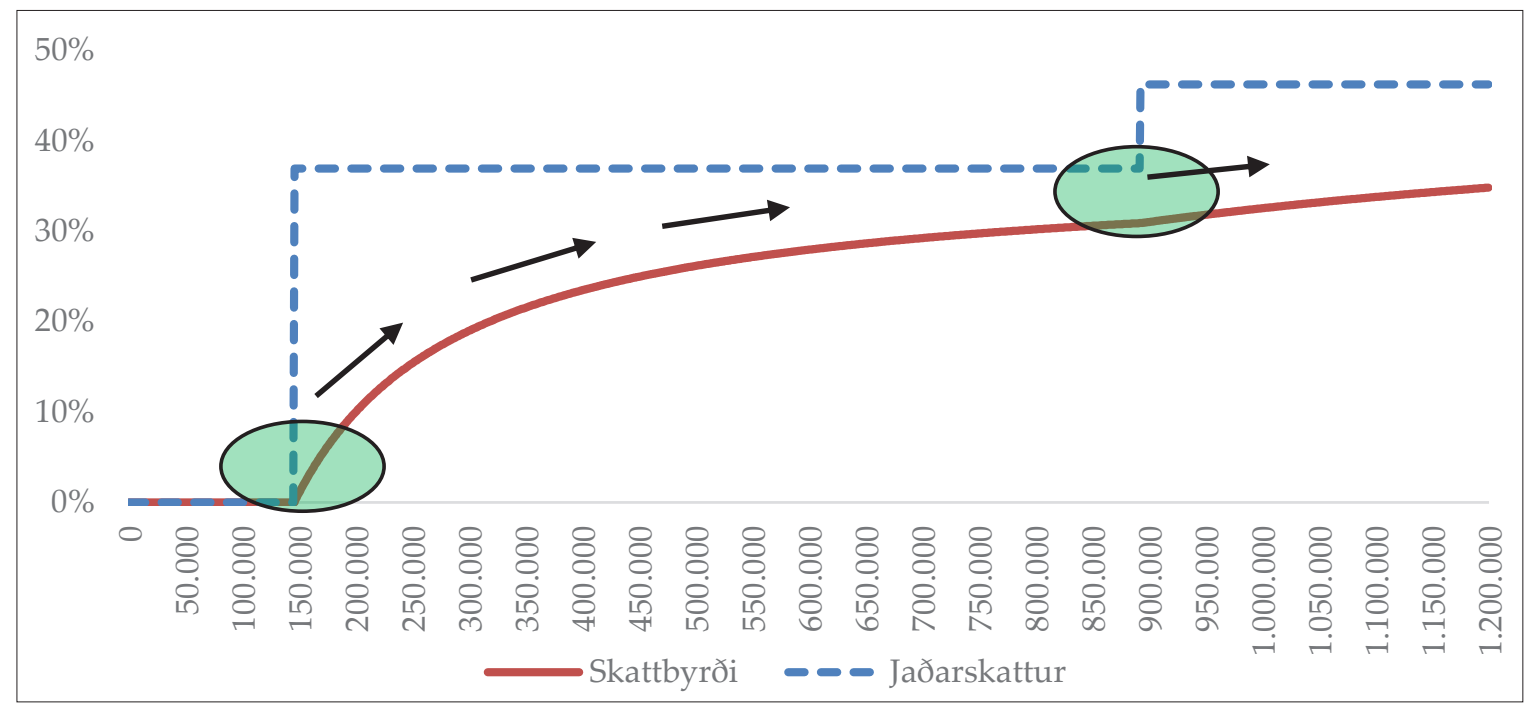

Mynd 7. Áhrif raunskattsskriðs á skattbyrðina.

Framangreind tenging verðlags við persónuafslátt mun jöfnum höndum draga úr skattbyrði í niðursveiflu, par sem laun eru almennt tregbreytanleg niður á við og standa frekar í stað pegar verðlag hækkar. Pegar viðmiðunarfjárhæðir kerfisins fylgja ekki próun kaup-

nefnt par sem tekið er tillit til skylduframlaga í lífeyrissjóð. Рað myndi pýða að í jöfnu 16 bættist við 0,04w og 0,115w í teljara og í jöfnu 17 bættust við 0,04 og 0,115.

21 Í núverandi kerfi par sem persónuafsláttur er tengdur verðlagspróun og marki efra tekjupreps launavísitölu verða áhrif skattskriðsins fyrir framteljendur í efra tekjuprepi mildari vegna pess að persónuafslátturinn vegur mun minna fyrir pá auk pess sem efra markið hækkar í samræmi við kauplag. Með fjárlögum fyrir árið 2019 var tímabundið tekin úr sambandi sú ráđstöfun að mörk efra preps væru tengd vísitölu launa og voru pau pess í stað tengd vísitölu neysluverðs eins og persónuafsláttur. 
lags eftir verða til aðstæður í opinberum fjármálum sem stundum er vísað til undir formerkjum virkrar hagstjórnar eða sjálfvirkrar sveiflujöfnunar (e. automatic stabilisation). Petta má skýra með peim hætti að skattbyrði aukist í uppsveiflu en dragist saman í niðursveiflu, sem jafnar út hagsveifluna. Pessi sveiflujöfnun veldur pví síðan að yfir lengri tíma safnar ríkissjóður forða pegar vel árar en gengur á sama forða pegar í harðbakkann slær. Að pessu er vikið sérstaklega hér á eftir.

Á lengri tíma pegar kaupmáttur fer vaxandi pýðir petta að skattgreiðendum fjölgar, p.e. fleiri eru með tekjur yfir skattleysismörkum, og líka að skattbyrði vex. Próunin verður við pær aðstæður pegar ráðstöfunartekjur hafa aukist en hið opinbera tekur aukinn hlut af batnandi kjörum en minnkandi vægi persónuafsláttar dregur um leið úr jöfnunaráhrifum skattkerfisins. Að framansögðu má nú staldra við og greina pá próun staðgreiðslunnar með ofangreint að leiðarljósi um leið og litið er til aðstæðna pegar kerfið var innleitt fyrir 30 árum.

\subsection{Upphaf og próun kerfisins}

Núverandi tekjuskattskerfi á rætur að rekja til ársins 1988 með upptöku staðgreiðslu. Fyrir breytingarnar höfðu opinber gjöld fyrir hvert álagningarár verið gerð upp eftir á með tilheyrandi óvissu fyrir bæði gjaldendur og hið opinbera. Раð pýddi að áhrif verðbólgu á raunvirði tekna hins opinbera voru gífurleg, sér í lagi í ljósi pess að á pessum árum var ársverðbólga í kringum 40\%. ${ }^{22}$ Á sama hátt sátu einstaklingar oft uppi með háa bakreikninga, t.d. vegna árstíðarbundinnar vinnu eða niðursveiflu á vinnumarkaði. Tafarlausar mánaðargreiðslur, eins og tíðkast í staðgreiðslu, draga úr pessum áhrifum.

Meðfram innleiðingu staðgreiðslu gafst tækifæri til að sníða ýmsa aðra vankanta af fyrra fyrirkomulagi. Til að mynda voru sömu undanpágu- og frádráttarliðir ekki heimilaðir við greiðslu tekjuskatts til ríkisins og útsvars til sveitarfélaga. Рað olli mismun í tekjuskatts- og útsvarsstofni. Undið var ofan af pessu með upptöku fasts alhliða skattafsláttar (persónuafsláttar), sem var óháður hjúskaparstétt og fjölskyldustærð. ${ }^{23}$ Hann var töluvert hærri en samanlagðir fastir frádráttarliðir fyrra kerfis. Var pað gert til að vega á móti afnámi hlutfallslegra frádráttarliða, svo sem iðgjalda til lífeyrissjóða og 10\% launatekna. Tekjuskattur og útsvar miðuðust pví við sama skattstofn, sem var breiðari en fyrri stofnar. Samhliða pessu voru álagningarreglur einfaldaðar, viðbótarálagsprep afnumin og tekið upp eitt skatthlutfall (35,2\%) í stað priggja sem áður höfðu verið. Nýja skatthlutfallið skiptist í tekjuskatt til ríkisins (28,5\%) og útsvar til sveitarfélaga (6,7\%). Breytingunum frá 1988 má í megindráttum lýsa með eftirfarandi hætti: ${ }^{24}$

- Skattstofnar voru sameinaðir og breikkaðir.

o Skattstofn tekjuskatts var breikkaður með afnámi undanpáguliða (iðgjöld í lífeyrissjóði og líftryggingar, stéttarfélagsgjöld o.fl.).

o Skattstofn útsvarsgreiðslna var breikkaður með afnámi útsvarsafslátta.

o Við afnám afsláttar- og undanpáguliða (frádráttarliða) miðuðust tekjuskattur og útsvarsgreiðslur við sama stofn.

o Í stað ólíkra frádráttarliða frá tekjuskatti og útsvari var tekinn upp fastur alhliða skattafrádráttur (persónuafsláttur).

- Fallið var frá premur tekjuskattshlutföllum (19,5\%, 30,5\% \& 43,5\%) og einu útsvarshlutfalli (10,2\% í Reykjavík). Í stað pess var tekið upp eitt skatthlutfall við staðgreiðslu (35,2\%) sem skiptist í tekjuskatt til ríkisins (28,5\%) og útsvar til sveitarfélaga $(6,7 \%)$.

o Með öðrum orðum voru viðbótarálagsprep aflögð.

22 Meðalársverðbólga á árunum 1980-1988 var 39,15\%.

23 Pó var heimilt að færa 80\% persónuafsláttar milli hjóna. Árið 2003 varð persónuafsláttur millifæranlegur að fullu.

24 Upptalningin byggist á skilabréfi og greinargerð jaðarskattanefndar (fjármálaráðuneytið, 1997, bls. 4). 
- Sjómannafrádráttur varð að föstum skattafrádrætti á hvern lögskráđan dag.

- Vaxtagjöld vegna íbúðarkaupa hættu að vera frádráttarbær frá skattstofni. Pess í stað var tekinn upp tímabundinn vaxtaafsláttur auk húsnæðisbóta vegna fyrstu kaupa eða nýbygginga.

Við pað að fækka skattprepunum úr premur (voru fjögur með útsvarinu) í eitt lækkuðu jaðarskattar peirra hærra launuðu en jaðarskattar láglaunafólks jukust á hinn bóginn töluvert. Á móti pessum jaðaráhrifum vó hár persónuafsláttur. Eins og sjá má í töflu 2.1 lækkaði hæsti jaðarskattur um 18,9 prósentustig á milli áranna 1986-1988 en á sama tíma hækkaði sá lægsti um 6,9 prósentustig. Hinn nýi persónuafsláttur var hár sem gerði pað að verkum að skattleysismörkin hækkuðu um 89,3\% milli pessara tveggja ára. Skattbyrði hinna lægst launuðu minnkaði pví eftir allt saman vegna pess hve margir höfðu tekjur undir skattleysismörkum. Aftur á móti breyttist skattbyrði meðallauna lítið, eða um 1,3\%. Раð gefur pví auga leið að færri launpegar stóðu undir megni opinberra gjalda, enda fækkaði peim sem greiddu tekjuskatt til ríkisins í hlutfalli við útsvarsgreiðendur um 8,5\% og tekjuskattur sem hlutfall af útsvarsstofni dróst einnig verulega saman, sjá myndir 8 og 9. Pá fór hlutfall peirra sem almennt greiddu tekjuskatt til hins opinbera niður í um $60 \%$. Pannig varð til nýtt kerfi staðgreiðslu með einni skattprósentu og persónuafslætti sem var í formi skattkorts sem launagreiðandi tók við og veitti heimild til frádráttar á staðgreiðslu. Samkvæmt skilgreiningu með hinu einfalda kerfi varð pví staðgreiðslan rétt og stemmdi við álagningu næsta árs og uppgjör. Stóra viðfangsefnið með staðgreiðslunni varð hversu há grunnprósentan reyndist og að framteljendur lentu á vegg jaðaráhrifa pegar skattleysismörkum sleppti með samsvarandi letjandi áhrifum á vinnuframboð.

Tafla 1. Breytingar á jaðarskatti einstaklings frá 1986-1988.25

\begin{tabular}{|c|c|c|c|}
\hline & $\begin{array}{r}1986 \\
\text { pús. kr. }\end{array}$ & $\begin{array}{r}1988 \\
\text { pús. kr. }\end{array}$ & $\begin{array}{r}\text { Breyting } \\
\% \text { eða \%-stig }\end{array}$ \\
\hline Skattleysismörk & 280 & 530 & 89,3 \\
\hline Lægsti jaðarskattur, \% & 28,3 & 35,2 & 6,9 \\
\hline Hæsti jaðarskattur, \% & 56,3 & 35,2 & $-21,1$ \\
\hline \multicolumn{4}{|l|}{ Til samanburðar: } \\
\hline Meðallaun einstaklings & 555 & 686 & 23,6 \\
\hline Skattleysismörk sem \% af meðallaunum & 50,5 & 77,3 & 26,8 \\
\hline Skattbyrði miðað við meðallaun, \% & 7,9 & 8,0 & 0,1 \\
\hline Par af útsvar \% - stig 26 & 6,9 & 6,7 & $-0,2$ \\
\hline Tekjuskattsgreiðendur í hlutfalli við greiðendur útsvars \% & 54,3 & 49,7 & $-4,6$ \\
\hline
\end{tabular}

Heimild: Skilabréf og greinagerð jaðarskattanefndar (fjármálaráðuneytið,1997, bls. 5),

Ríkisskattstjóri, Hagstofa Íslands og eigin útreikningar.

Af pessum tölum má ráða að eitthvað hafi verið gefið eftir varðandi tekjuöflunina sem kann að vera skýring pess að fyrir tekjuárið 1989 var strax horfið frá sjálfvirkri uppfærslu persónuafsláttar, sem í upphafi miðaðist við lánskjaravísitölu. ${ }^{27}$ Breytingar urðu pá sjálfstæð ákvörðun hverju sinni. Pví til viðbótar var tekjuskattshlutfallið hækkað. Með pví lækkuðu skattleysismörkin. Kerfinu hefur síðan verið stjórnað meira og minna með pessum hætti, p.e.a.s. persónuafsláttur stendur nánast í stað á föstu verðlagi (eins og ráða má af mynd 14)

25 Upphæðir eru á verðlagi ársins 1988.

26 Útsvarshlutfallið var lækkað svo að sveitarfélögin héldu pví sem næst sömu tekjum.

27 Lánskjaravísitalan var að priðjungi verðlag, priðjungi byggingarvísitala og priðjungi laun. Byggingarvísitala er að stórum hluta laun. Рað pýðir að innbyggt var í upphafi að viðmiðunarfjárhæð kerfisins tæki að miklu leyti mið af launapróun. 
en skatthlutfallið (meðalútsvar + tekjuskattur, á töflu 3) er notað fyrir tekjuöflun og skattleysismörkin hreyfast í kjölfarið (mynd 14 og tafla 3). Мeð öðrum orðum hefur talsvert raunskattskrið átt sér stað innan kerfisins til að mæta aukinni tekjuöflunarpörf ríkisins og samhliða pessu hefur orðið tilfærsla í tekjuöflun frá óbeinum sköttum til beinna. Inn í pessa sögu tvinnast próun á efra prepi, p.e. próun prósentunnar og viðmiðunarfjárhæð pess og stutt tímabil fjölprepakerfis frá árunum 2010-2016. Heildarlýsing á pessari atburðarás sést til að mynda í pví hvernig meðaltekjuskattur hefur próast frá 1981, líkt og sjá má á mynd 8. Athygli vekur að meðalhlutfallið var í lágmarki við upphafi kerfisins og náði ekki fyrri stöðu fyrr en undir aldamótin síðustu.

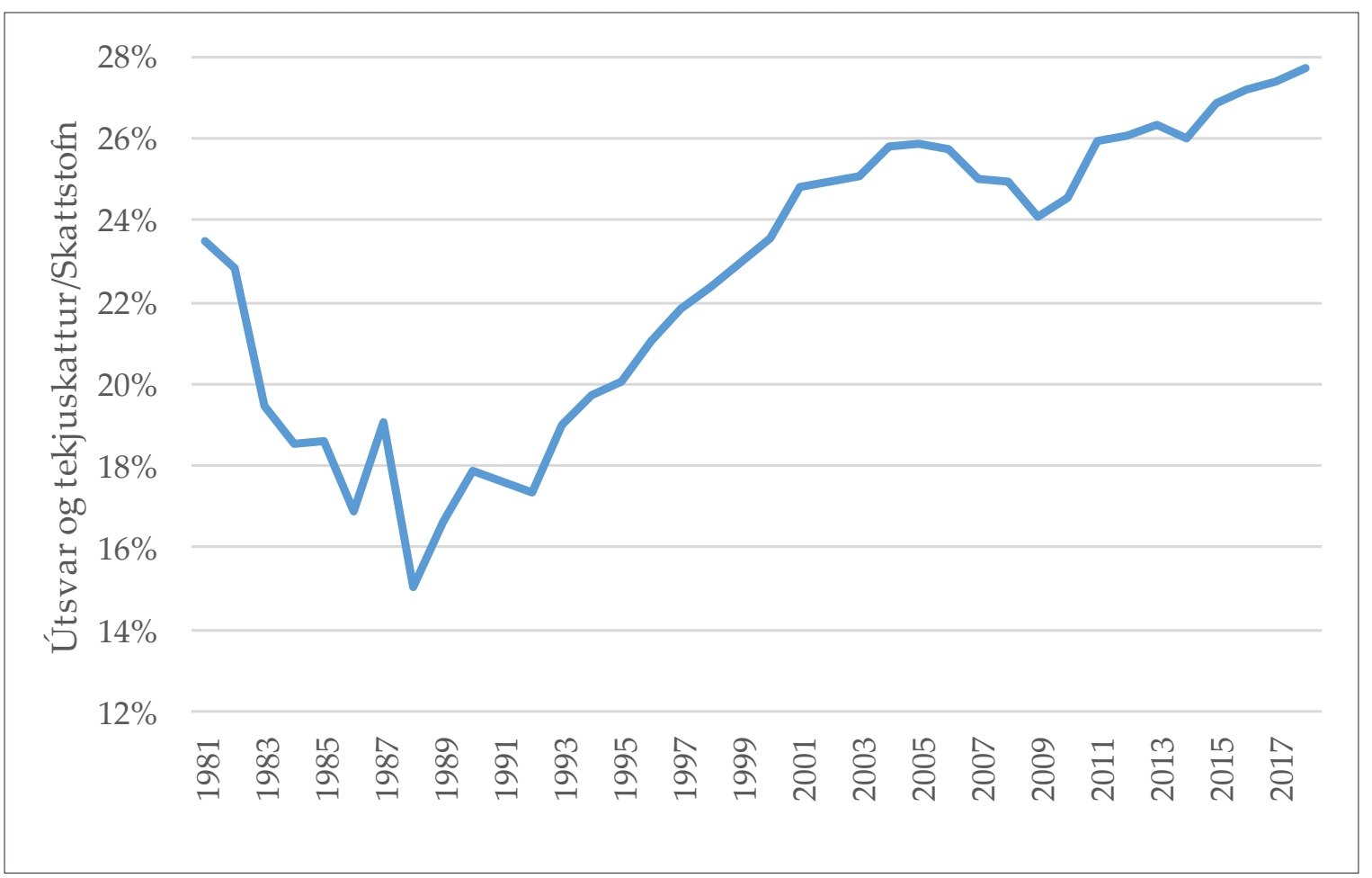

Mynd 8. Tekjuskattur og útsvar að frádregnum persónuafslætti í hlutfalli við skattskyldan stofn tekjuárin 1981-2018.

Heimild: Ríkisskattstjóri og eigin útreikningar.

Sams konar mynd og pessi fæst pegar skoðaður er fjöldi framteljenda sem greiðir skatt til ríkissjóðs í hlutfalli við framteljendur. Petta næst einna best með pví að taka fjölda greiðenda útsvars, sem er í eðli sínu flatur skattur (greiddur af ríki fyrir pá sem eru undir skattleysismörkum), og bera saman við greiðendur tekjuskatts til ríkisins, p.e. fjölda peirra sem eru með tekjur yfir peim mörkum pegar peir greiða orðið meira en einungis útsvarið og ríkið fær eiginlegan tekjuskatt. Pá sést hvernig greiðendum tekjuskatts til ríkissjóðs fækkaði við upptöku staðgreiðslunnar og fjölgaði síðan. Fjöldinn hreyfist líka samfara efnahagsástandinu á hverjum tíma og pjónar sem tæki til virkrar hagstjórnar sem vikið er að síðar. 


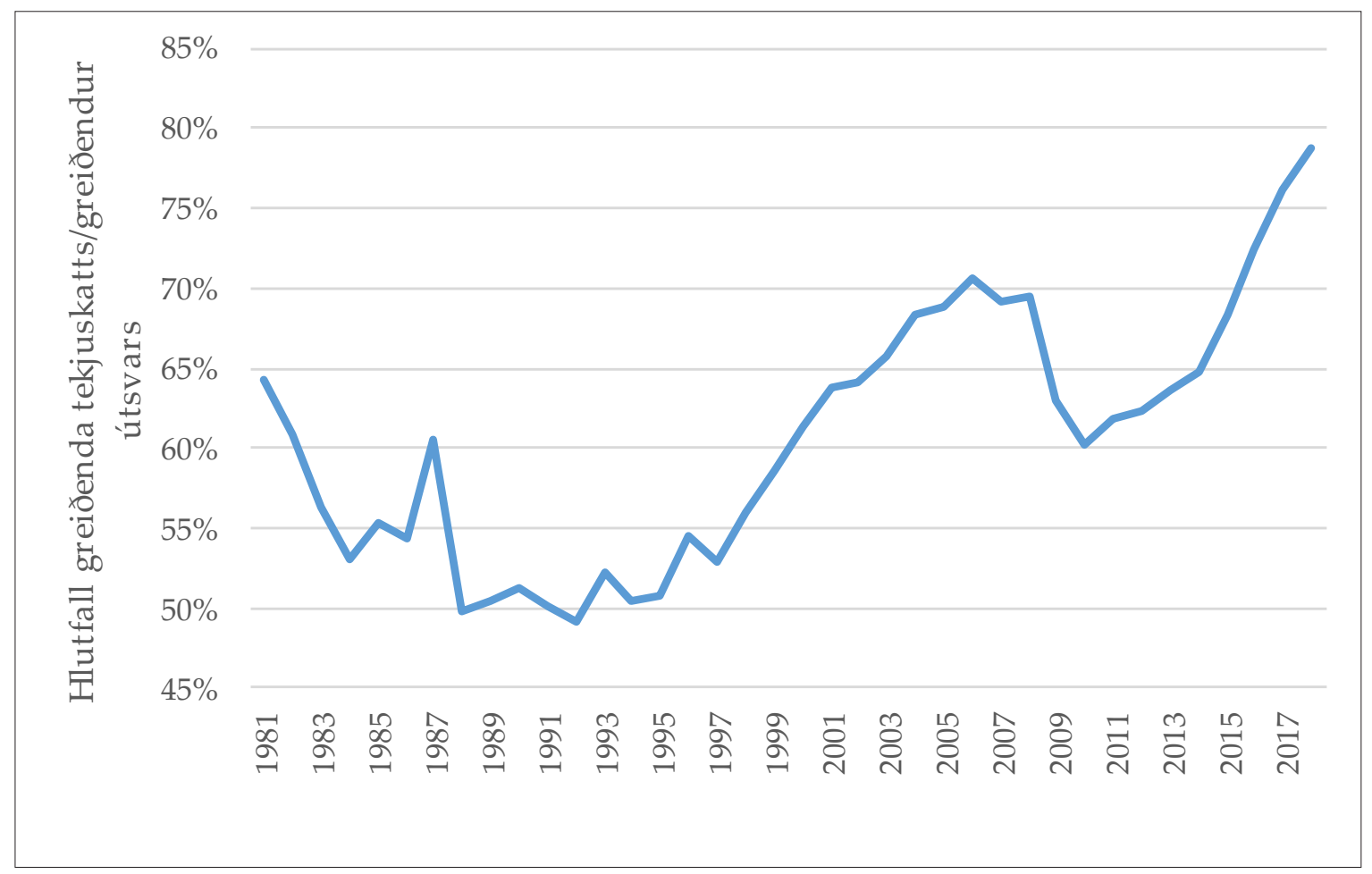

Mynd 9. Hlutfall greiðenda tekjuskatts til ríkissjóðs á móti greiðendum útsvars 1981-2018.

Heimild: Ríkisskattstjóri og eigin útreikningar.

Hvað skattgreiðendur varðar eru pað greiðslur til hins opinbera sem skipta máli, p.e. tekjur yfir skattleysismörkum bera skatt. Til að byrja með renna pær að fullu til greiðslu útsvarsins og pegar ákveðnum mörkum er náð duga greiðslurnar bæði fyrir útsvarinu og mynda skatttekjur fyrir ríkissjóð. Myndin að framan sýndi hlutfall virkra greiðenda yfir tíma til ríkissjóðs. Myndin hér á eftir sýnir hins vegar hlutfall framteljenda sem greiða skatt til hins opinbera, p.e. skattgreiðendur með tekjur yfir skattleysismörkum, og er pað borið saman við nýjustu upplýsingar frá Noregi (gráa boxið) og Danmörku (rauða boxið). Myndin nær yfir styttra tímabil, en myndin af hlutfalli greiðenda til ríkissjóðs er mjög svipuð yfir sama tímabil. 


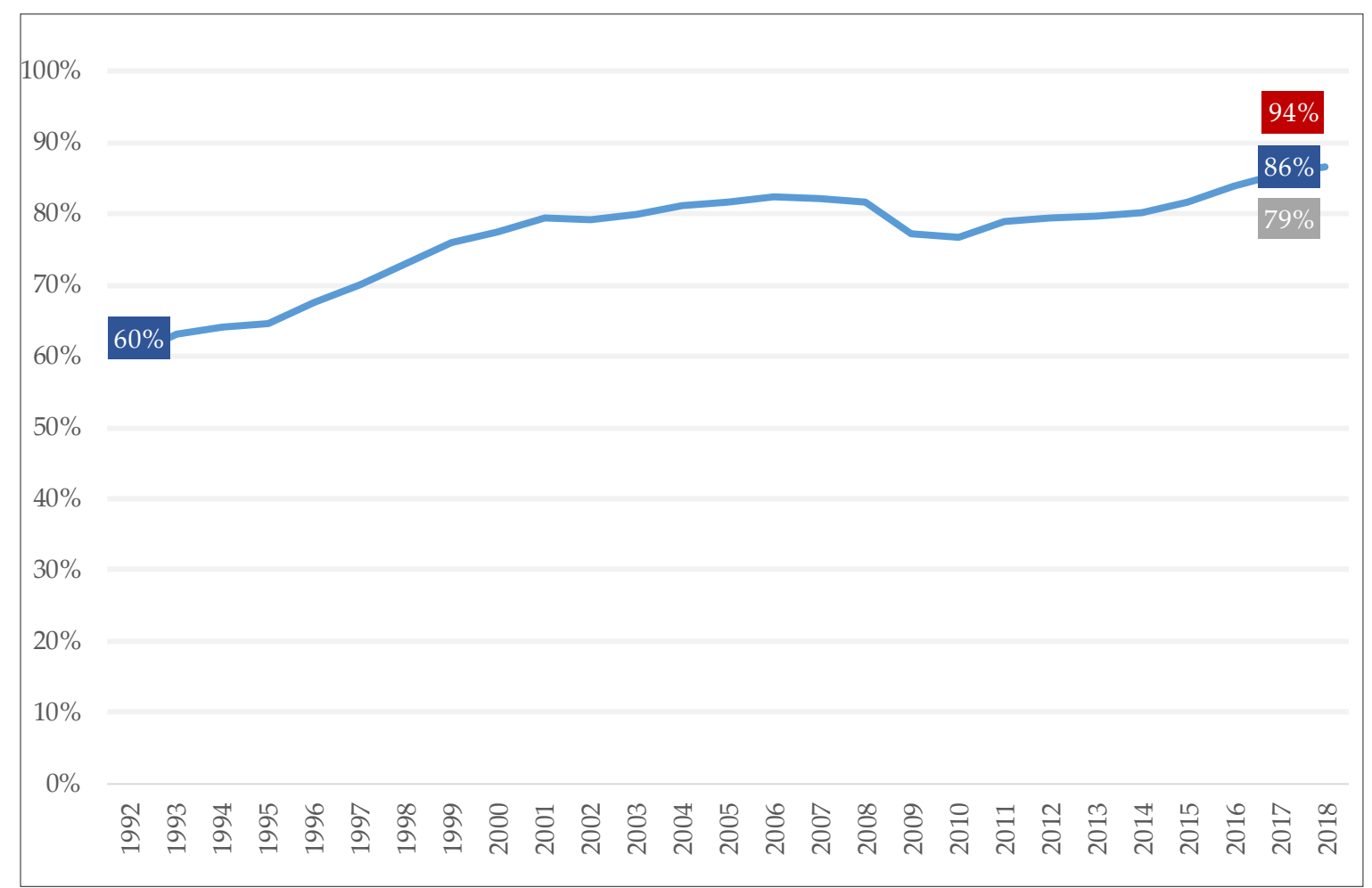

Mynd 10. Próun á hlutfalli peirra sem greiða tekjuskatt til hins opinbera 1992-2018 auk samanburðar við Danmörku (rautt box) og Noreg (grátt box) 2017.

Heimild: Ríkisskattstjóri.

\subsection{Fjármögnun og stærð hins opinbera}

Í umræðu um skattbyrði í kerfi tekjuskatts verður að taka tillit til pess að önnur tekjuöflun hins opinbera skiptir máli. Hvað próunina í beinum og óbeinum sköttum varðar er vert að hafa í huga að pað er einkenni vanpróaðrar tekjuöflunar að vægi ýmissa óbeinna skatta sé hátt og beinna skatta á móti lágt. Að leggja skatt á afurðir í formi tolla, vörugjalda og annarra gjalda á afurðir var lengi vel ódýrara í framkvæmd en skattlagning á vinnuafl og fjármuni. Pessi skattlagning á afurðir einkenndist oft og tíðum af margbreytilegri gjaldtöku, skekkti hlutfallsverð og bjagaði verðmyndun. Með upptöku á virðisaukaskatti í stað söluskatts á sama tíma og staðgreiðslan var tekin upp var verið að nútímavæða tekjuöflunina með breiðum stofnum sem drógu úr truflandi áhrifum skatta á markaði. Skattkerfi, par sem veltuskattar vógu pungt og undanpágur voru margar, líkt og á dögum söluskattsins, hafði tilhneigingu til að magna sveiflur efnahagslífsins. Hvað tekjuskattsinnheimtuna snertir benda Jóhannes Karlsson og Pórólfur Matthíasson (2015) á að lengi vel hafi illa gengið að afla stuðnings við tekjuskattsinnheimtu vegna umfangsmikilla skattsvika í tengslum við tekjuskattskerfið og pannig hafi stjórnmálamenn neyðst til að nota tekjuöflun með óbeinum sköttum.

Рað er ekki einungis að beinir skattar hafi áhrif á ráðstöfunartekjur og stöðu heimila, óbeinir skattar gera pað líka. Mynd 11 sýnir hvernig hlutur beinna og óbeinna skatta af vergri landsframleiðslu hefur próast frá 1980. Báðir tekjustofnarnir eru vitaskuld mjög hagsveiflutengdir en engu að síður er leitnin ótvíræð. Beinir skattar hafa vaxið en vægi óbeinna skatta hefur minnkað. Óbeinir skattar leggjast um margt hlutfallslega pyngra á lágtekjuhópa pví að peir eru hlutfallslegir og leggjast á neyslu fremur en sparnað. Hlutfallslega hærri hlutdeild ráđstöfunartekna fer til neyslu hjá lágtekjuhópum og pannig ípyngir óbeinn skattur peim umfram aðra sjá Decoster og fél. (2010) um petta. 


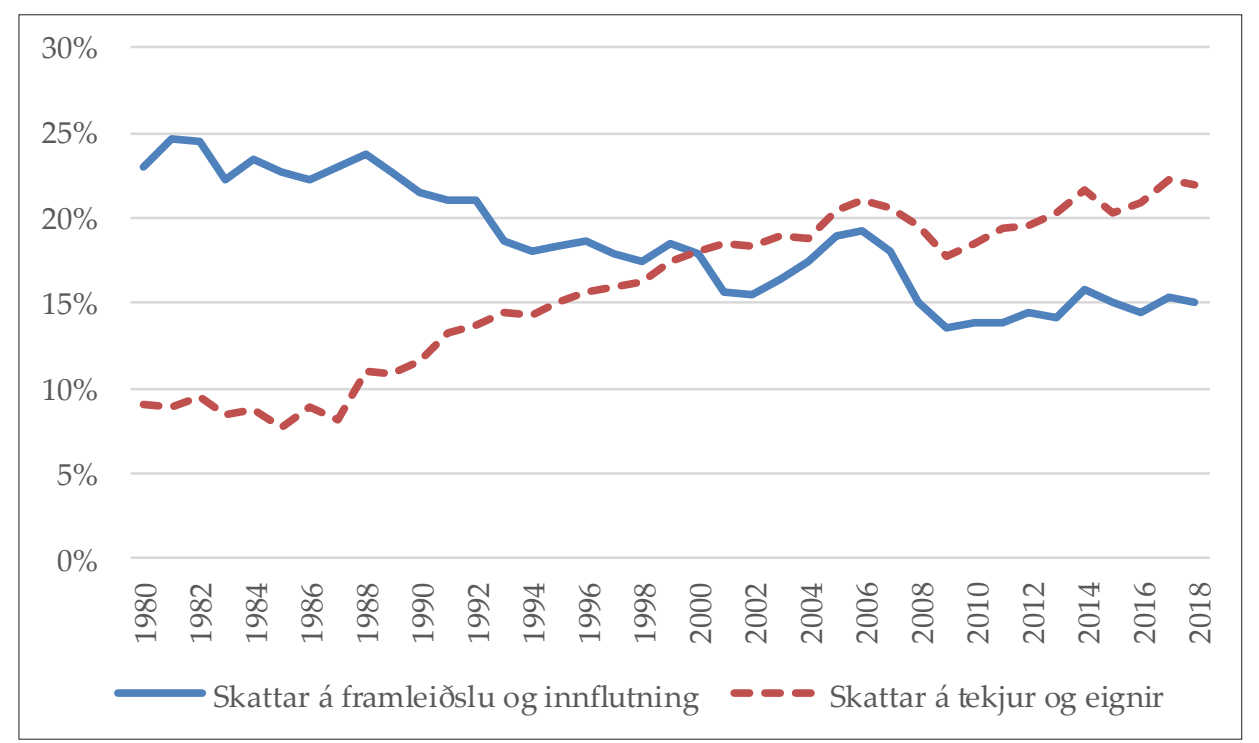

Mynd 11. Hlutur beinna og óbeinna skatta af vergri landsframleiðslu á tímabilinu 19802018.

Heimild: Hagstofa Íslands og eigin útreikningar.

Reikna má út að af hverri krónu sem einstaklingur aflar og seld er á markaði geti hann keypt framleiðsluverðmæti án óbeinnar skattlagningar að teknu tilliti til beins skatts sem svarar til ákveðins brots af upphaflegu krónunni. Petta brot mælir hlutfallið sem skattgreiðandi heldur eftir og er 1 mínus skattfleygurinn, p.e. hlutfallið sem greitt er í skatt.

$$
1-\text { skattfleygur }=(1-\text { hlutfall beins skatts }) /(1+\text { hlutfall óbeins skatts }) \text {. }
$$

Einn mínus skattfleygurinn, sem mæling á pví sem aðilar halda eftir, minnkar pví við hærri beina skatta og hærri óbeina skatta. Gróflega má reikna pennan fleyg í pjóðhagslegu tilliti með gögnunum sem fram koma á myndinni hér að framan. Fleygurinn vex fyrir tilstuðlan aukinna beinna skatta og dregst saman fyrir pá sök að vægi óbeinna skatta hefur minnkað. Á heildina litið sést hvernig hlutfallið hefur minnkað sem einstaklingurinn heldur pví að skattfleygurinn hefur vaxið.

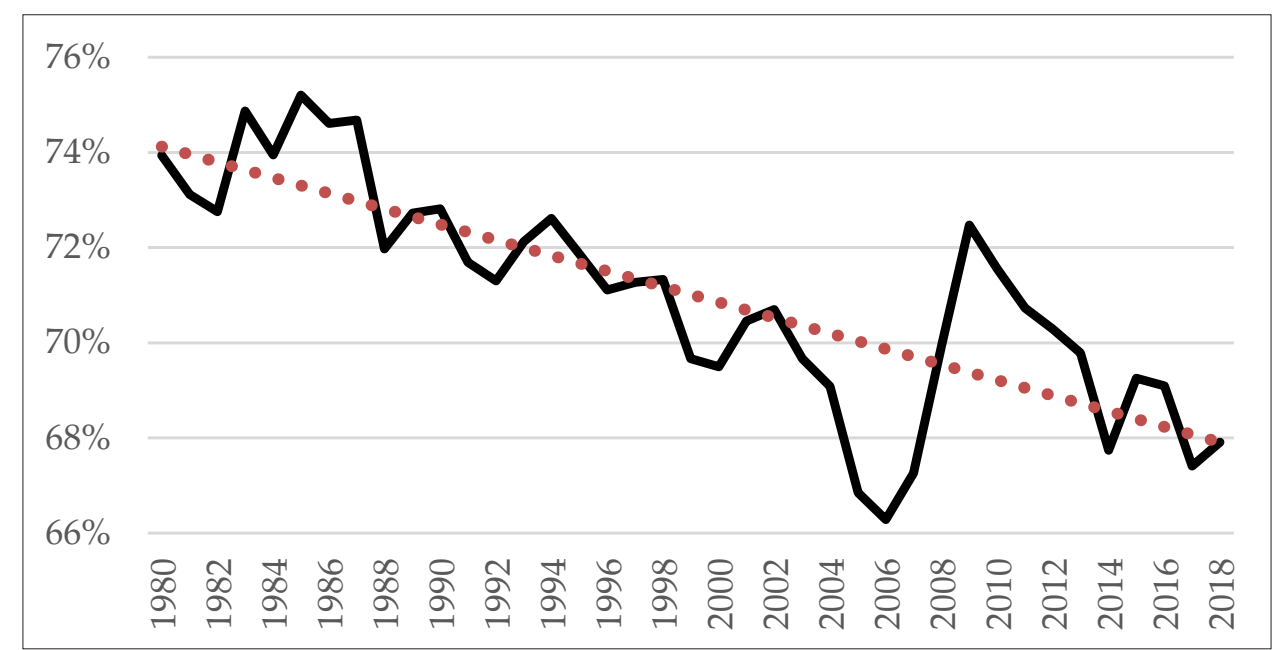

Mynd 12. Раð sem er að meðaltali til skipta hverrar krónu á markaði að teknu tilliti til beinna og óbeinna skatta á tímabilinu 1980-2018. 
Tekjuöflunina sem hér hefur verið lýst er svo hægt að setja í samhengi við fyrirferð hins opinbera í tekjum og gjöldum sem hefur vaxið á undanförnum 40 árum.

Tafla 2. Umfang hins opinbera í tekjum og gjöldum 1980-2018. ${ }^{28}$

\begin{tabular}{ccc}
\hline & $\begin{array}{c}\text { Tekjur \% af vergri } \\
\text { landsframleiðslu }\end{array}$ & $\begin{array}{c}\text { Gjöld \% af vergri } \\
\text { landsframleiðslu }\end{array}$ \\
\hline $1980-1990$ & 37 & 38 \\
$1991-2000$ & 40 & 42 \\
$2001-2010$ & 42 & 43 \\
$2011-2018$ & 42 & 43 \\
\hline
\end{tabular}

Heimild: Hagstofa Íslands og eigin útreikningar.

Í töflunni eru tekin meðaltöl tekna og gjalda eftir áratugum. Útgjaldahlutfallið hefur vaxið um 5 prósentustig af landsframleiðslu og er pað nokkurn veginn í takt við próunina sem mælikvarðinn að framan sýndi. Hann hafði lækkað um 6 prósentustig sem stóð gróflega undir nefndri útgjaldaaukningu en um leið verður að hafa pann fyrirvara að hann nær ekki yfir alla tekjuöflun hins opinbera. Á sama tíma hefur tekjuhlutfallið samkvæmt töflunni vaxið um 4 prósentustig.

Hægt er að sjá frekari sundurliðun tekjuöflunar hins opinbera, sem sést á næstu mynd. Myndin nær yfir 38 ár og sýnir pví langtímapróun í samsetningunni. Par sem myndin sýnir hið opinbera er útsvarið talið með í tekjuskatti einstaklinga og innbyrðis vægi hvors um sig hefur einnig breyst mikið.

Ýmislegt má lesa af myndinni. Virðisaukaskattur vó um 30\% af heildinni fyrstu tíu árin, síðan heldur minna, eða 27-29\%, fram til ársins 2007 pegar neðra prepið var lækkað í 7\%, en pá gaf virðisaukaskatturinn mikið eftir. Virðisaukaskattsvelta í almenna prepinu var mjög lengi að ná sér á strik aftur eftir fjármálaáfallið; veltan í neðra prepi er óteygnari fyrir verðbreytingum og hélt sér betur en stofn hennar var svo útvíkkaður árið 2016 og náði pá til ferðapjónustu auk pess sem neðra prepið var hækkað í 11\%. Prátt fyrir að ferðapjónustu hafi verið bætt inn í myndina tvö síðustu árin vegur virðisaukaskattur í heild enn mun minna en hann gerði í upphafi. Tollar og vörugjöld vógu mjög pungt á níunda áratugnum en pað hefur gjörbreyst. Skattar á fjármagn eru summa tekjuskatts lögaðila og fjármagnstekjuskatts einstaklinga eftir tilkomu pess síðarnefnda árið 1997. Pessi páttur hefur leitni til aukningar, pótt fjármálaáfallið hafi breytt pví tímabundið. Margt fleira má tína hér til sem minna vegur.

28 Í útreikning meðaltala er árunum 2008 í gjöldum, upphafsári fjármálaáfallsins, og 2016 í tekjum, uppgjörsári slitabúanna, sleppt. 


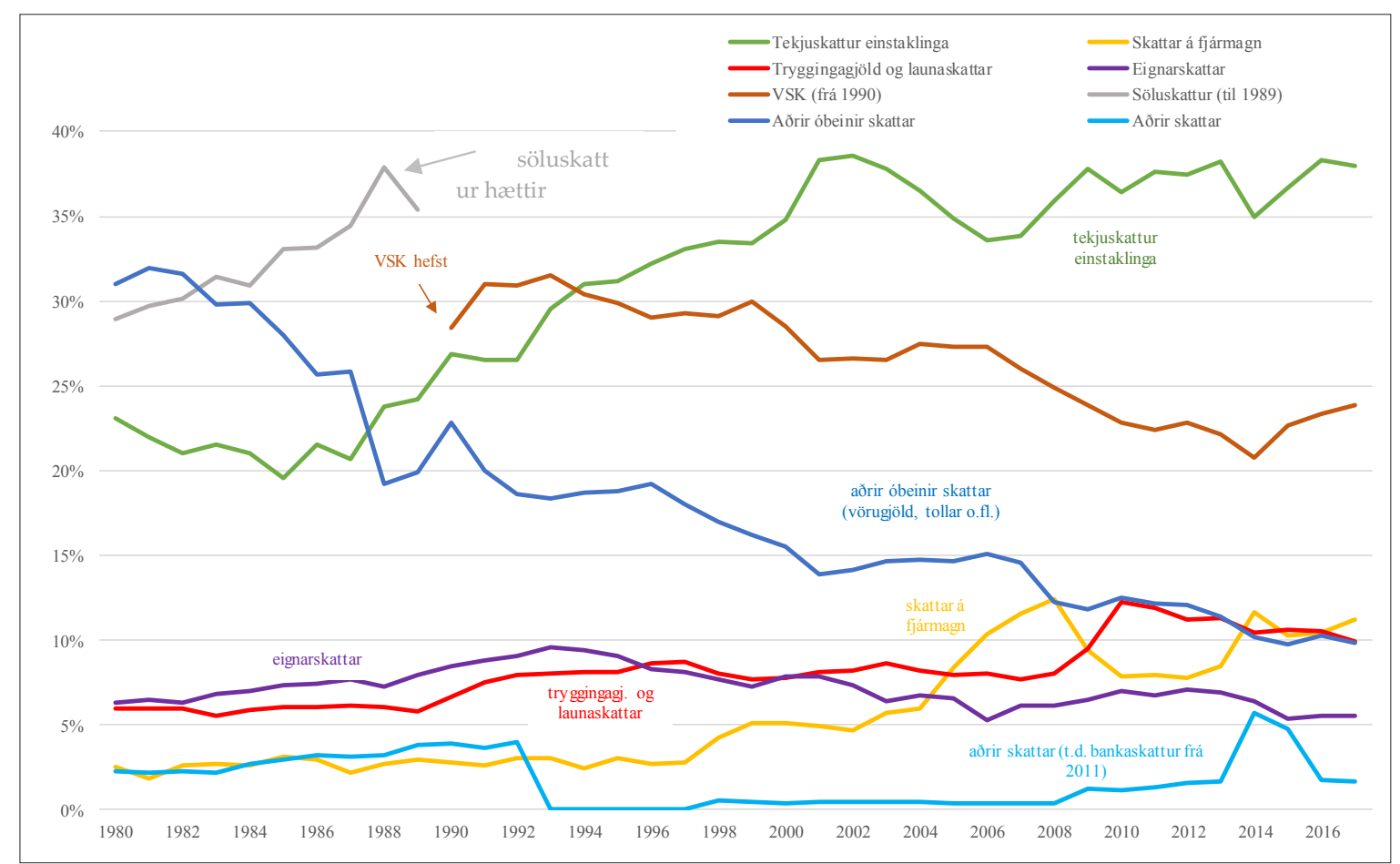

Mynd 13. Samsetning skatttekna hins opinbera 1980-2017.

Heimild: Fjármála- og efnahagsráðuneytið.

\subsection{Viðmiðunarfjárhæðir og skattprósentur}

Nú hefur verið fjallað um eiginleika kerfisins og próun heildarstærða en viðmiðunarfjárhæðir og prósentur skipta lykilmáli pegar litið er til próunar á kerfi tekjuskatts. Um leið er mikilvægt að halda til haga peirri umfjöllun sem áður hefur verið vikið að hvað varðar samspil persónuafsláttar og skattleysismarka. Mynd 14 sýnir próun pessara stærða á föstu verðlagi. Af henni má ráða hvernig skattleysismörkin lækkuðu í kjölfar hækkunar skattprósentunnar 1988-1992 pegar persónuafsláttur var nokkuð stöðugur. Pá sést jafnframt að persónuafslátturinn gaf lítillega eftir á árunum 1997-2004. Á fyrri hluta pess tímabils gerðu skattleysismörk pað ekki vegna pess að grunnprósentan var líka lækkuð og svo lækkuðu skattleysismörkin lítillega á seinni hluta umrædds tímabils pegar grunnprósentan hækkaði við hækkun útsvars.

Hér er ekki tekið tillit til pess við útreikning skattleysismarka að skylduframlag launpega í lífeyrissjóð er frádráttarbært frá skattstofni og pað er ígildi lækkunar á skattskyldu fyrir launpega. Sú próun var tekin inn í skrefum á árunum 1995-1997. Við útreikninginn er heldur ekki sýnt hvernig framlag í séreignarsjóð hefur haft áhrif á skattleysismörkin en pað er próun sem var í tveimur skrefum, 1999 og 2000, og gefur launagreiðanda kost á að greiða $\%$ framlag og launpega $4 \%$ framlag í séreignarsjóð og mynda um leið frádrátt frá skattstofni. 


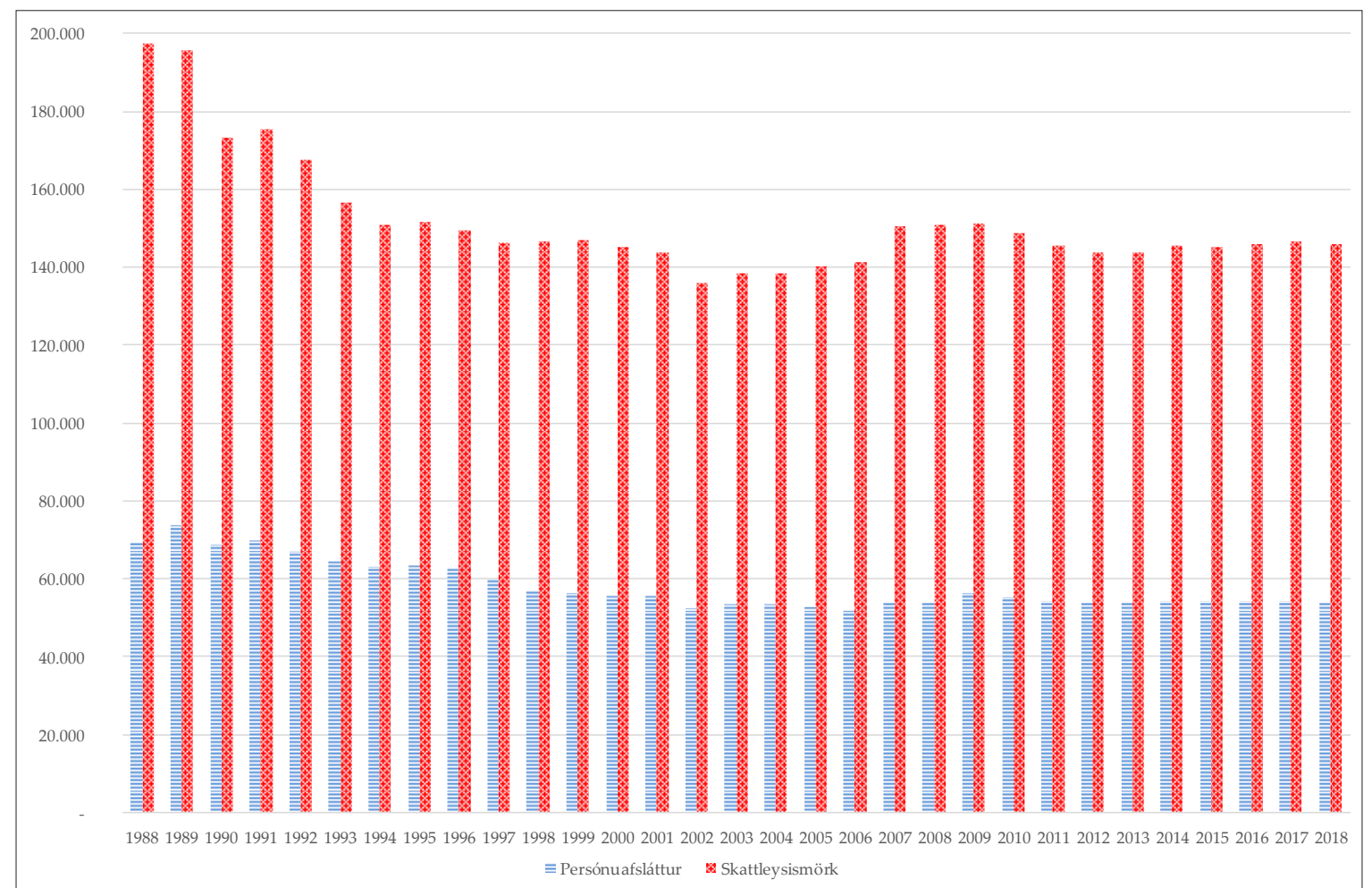

Mynd 14. Persónuafsláttur og skattleysismörk skattskyldra tekna (verðlag 2018), tekjuárin 1988-2018.

Heimild: Hagstofa Íslands, Ríkisskattstjóri og eigin útreikningar.

Samspil persónuafsláttar og grunnprósentu ákvarða skattleysismörk sem eru afleidd stærð líkt og áður segir. Núverandi fyrirkomulag við uppfærslur persónuafsláttar sem er í upphafi hvers árs í réttu hlutfalli við mismun á vísitölu neysluverðs við upphaf og lok næstliðins tólf mánaða tímabils hefur birst á eftirfarandi hátt í lögum:

- Í fyrsta sinn með lögum nr. 174/2006. Miðað við vísitölu neysluverðs. Gildistaka 1. janúar 2008. Var pví í gildi árin 2008 og 2009.

- Hækkun persónuafsláttar í samræmi við vísitölu neysluverðs var afnumin með lögum nr. 128/2009. Gildistaka 1. janúar 2010. Var pví úr sambandi árin 2010 og 2011.

- Aftur lögfest með lögum nr. 73/2011. Miðað við vísitölu neysluverðs. Gildistaka 1. janúar 2012. Í gildi frá árinu 2012.

Framangreind próun skattleysismarka, sem upphaflega gáfu eftir á föstu verðlagi en hafa síðan verið nokkuð stöðug, hefur um margt yfirgnæft aðra áhrifapætti skattkerfisins og gert pað аð verkum að skattbyrði stórs hluta skattgreiðenda hefur aukist með bættum kjörum. Hér skal pað endurtekið að mest hafa áhrifin verið fyrir pá sem eru með tekjur á peim hluta ferils skattbyrðar par sem sveigjan á ferlinum er mest og brattinn í samræmi við pað.

A eftirfarandi töflu má sjá próun skatthlutfalls á tekjur. Annar dálkur stendur fyrir útsvar til sveitarfélaga en priðji dálkur tekjuskatt ríkisins í grunnprepi. Síðasti dálkurinn stendur fyrir tekjuskatt ríkisins í efra prepi. Pá verður að nefna, eins og sést á töflunni, að á tímabilinu 2010-2016 voru prjú prep í tekjuskatti. Rétt er að leggja á pað áherslu að margar vörður og framvindubrot í próun skattkerfisins hafa verið í samráði við aðila vinnumarkaðsins í tengslum við kjarasamninga. 
Tafla 3. Próun skatthlutfalls á tekjur einstaklinga tekjuárin 1988-2018.

\begin{tabular}{|c|c|c|c|c|c|}
\hline Tekjuár & $\begin{array}{c}\text { Meðalútsvar } \\
\text { [1] } \\
\end{array}$ & $\begin{array}{c}\text { Tekjuskattur } \\
{[2]} \\
\end{array}$ & $\begin{array}{c}\text { Grunn- } \\
\text { prósenta } \\
{[1]+[2]}\end{array}$ & $\begin{array}{c}\text { Tekjuskattur } \\
\text { prep } 2 \\
\text { Viðbót }\end{array}$ & $\begin{array}{c}\text { Tekjuskattur } \\
\text { prep } 3 \\
\text { Viðbót } \\
\end{array}$ \\
\hline 1988 & $6,70 \%$ & $28,50 \%$ & $35,20 \%$ & & \\
\hline 1989 & $6,94 \%$ & $30,80 \%$ & $37,74 \%$ & & \\
\hline 1990 & $6,99 \%$ & $32,80 \%$ & $39,79 \%$ & & \\
\hline 1991 & $6,99 \%$ & $32,80 \%$ & $39,79 \%$ & & \\
\hline 1992 & $7,05 \%$ & $32,80 \%$ & $39,85 \%$ & & \\
\hline 1993 & $7,04 \%$ & $34,30 \%$ & $41,34 \%$ & & $5,00 \%$ \\
\hline 1994 & $8,69 \%$ & $33,15 \%$ & $41,84 \%$ & & $5,00 \%$ \\
\hline 1995 & $8,78 \%$ & $33,15 \%$ & $41,93 \%$ & & $5,00 \%$ \\
\hline 1996 & $8,79 \%$ & $33,15 \%$ & $41,94 \%$ & & $5,00 \%$ \\
\hline 1997 & $11,57 \%$ & $29,31 \%$ & $40,88 \%$ & & $5,00 \%$ \\
\hline 1998 & $11,61 \%$ & $27,41 \%$ & $39,02 \%$ & & $7,00 \%$ \\
\hline 1999 & $11,93 \%$ & $26,41 \%$ & $38,34 \%$ & & $7,00 \%$ \\
\hline 2000 & $11,96 \%$ & $26,41 \%$ & $38,37 \%$ & & $7,00 \%$ \\
\hline 2001 & $12,68 \%$ & $26,08 \%$ & $38,76 \%$ & & $7,00 \%$ \\
\hline 2002 & $12,79 \%$ & $25,75 \%$ & $38,54 \%$ & & $7,00 \%$ \\
\hline 2003 & $12,80 \%$ & $25,75 \%$ & $38,55 \%$ & & $5,00 \%$ \\
\hline 2004 & $12,83 \%$ & $25,75 \%$ & $38,58 \%$ & & $4,00 \%$ \\
\hline 2005 & $12,98 \%$ & $24,75 \%$ & $37,73 \%$ & & $2,00 \%$ \\
\hline 2006 & $12,97 \%$ & $23,75 \%$ & $36,72 \%$ & & \\
\hline 2007 & $12,97 \%$ & $22,75 \%$ & $35,72 \%$ & & \\
\hline 2008 & $12,97 \%$ & $22,75 \%$ & $35,72 \%$ & & \\
\hline 2009 & $13,10 \%$ & $24,10 \%$ & $37,20 \%$ & & $\begin{array}{c}8 \% \text { seinni hluta } \\
\text { árs }\end{array}$ \\
\hline 2010 & $13,12 \%$ & $24,10 \%$ & $37,22 \%$ & $6,00 \%$ & $2,90 \%$ \\
\hline 2011 & $14,41 \%$ & $22,90 \%$ & $37,31 \%$ & $6,00 \%$ & $2,90 \%$ \\
\hline 2012 & $14,44 \%$ & $22,90 \%$ & $37,34 \%$ & $6,00 \%$ & $2,90 \%$ \\
\hline 2013 & $14,42 \%$ & $22,90 \%$ & $37,32 \%$ & $6,00 \%$ & $2,90 \%$ \\
\hline 2014 & $14,44 \%$ & $22,86 \%$ & $37,30 \%$ & $6,50 \%$ & $2,44 \%$ \\
\hline 2015 & $14,44 \%$ & $22,86 \%$ & $37,30 \%$ & $6,50 \%$ & $2,44 \%$ \\
\hline 2016 & $14,45 \%$ & $22,68 \%$ & $37,13 \%$ & $7,90 \%$ & $1,22 \%$ \\
\hline 2017 & $14,44 \%$ & $22,50 \%$ & $36,94 \%$ & & $9,30 \%$ \\
\hline 2018 & $14,44 \%$ & $22,50 \%$ & $36,94 \%$ & & $9,30 \%$ \\
\hline
\end{tabular}

Heimild: Ríkisskattstjóri.

Hvað próun útsvarsins snertir eru stærstu breytingarnar skatthlutföllin og breytt vægi skattstofnsins milli ríkis og sveitarfélaga. Á pessu ári er staðgreiðsluhlutfall sveitarfélaga 14,44\% samanborið við 6,7\% 1988. Prennt skýrir að stærstum hluta pá hækkun. Í fyrsta lagi var aðstöðugjald sveitarfélaga fellt niður árið 1993 og ári síðar var sveitarfélögum veitt svigrúm til að hækka útsvarið um 1,7 prósentustig. Í öðru lagi tóku sveitarfélögin við rekstri grunnskóla af ríkinu en við pað færðust 2,7 prósentustig frá tekjuskatti til útsvars á árinu 1997. Í priðja lagi fluttust verkefni vegna málefna fatlaðs fólks yfir til sveitarfélaga árið 2011 og við pað fluttust 1,2 prósentustig frá tekjuskatti til útsvars og 0,04 prósentustig í viðbót 2014. Í pessu samhengi verður að nefna að sveitarfélög fá alla útsvarsprósentuna í sinn hlut af skattstofni. Ríkissjóður tryggir sveitarfélögunum pað. Ríkið greiðir sveitar- 
félögum pað sem á vantar fyrir hvern framteljanda og ber pannig allan kostnaðinn af persónuafslættinum. ${ }^{29}$

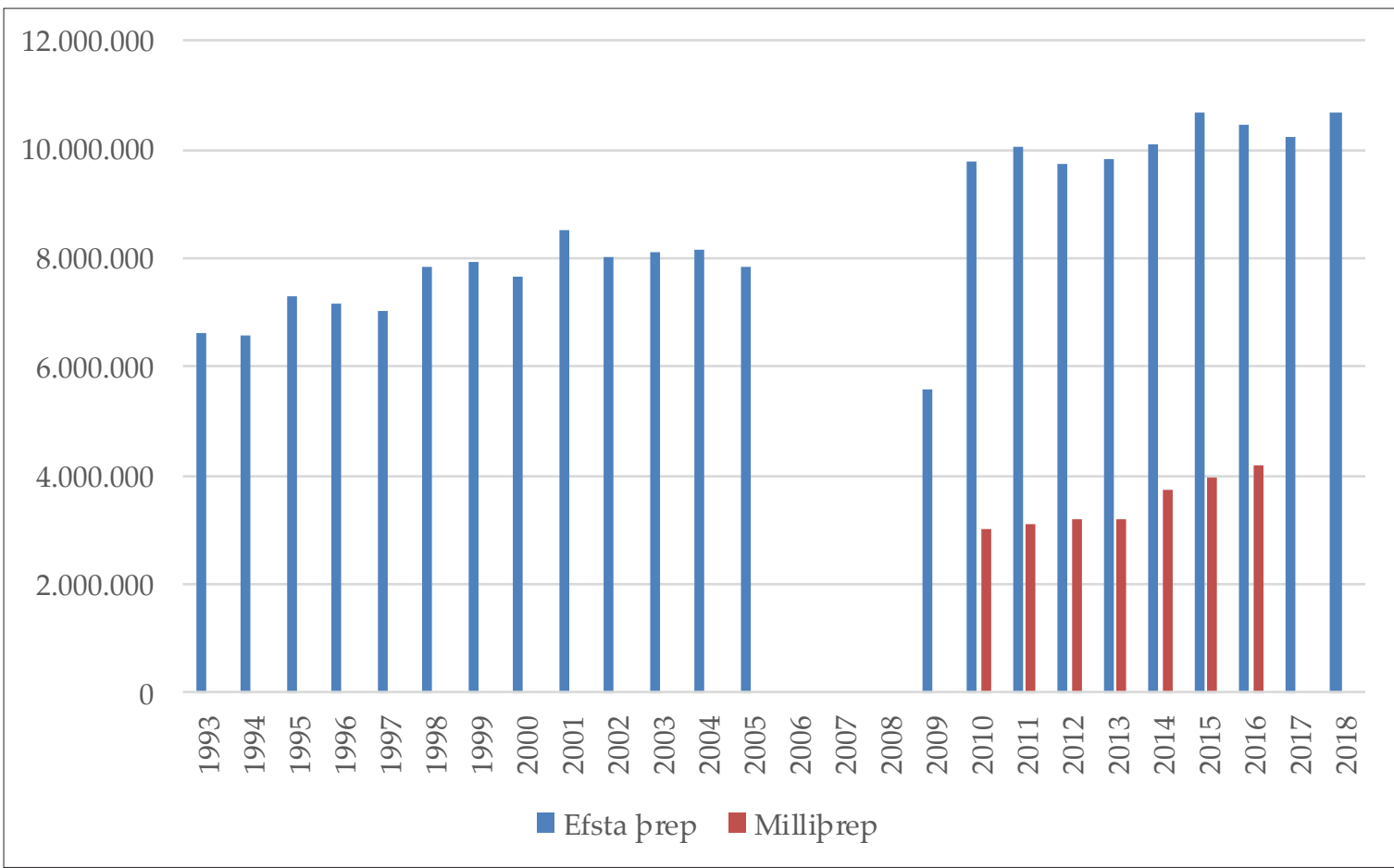

Mynd 15. Próun viðmiðunarfjárhæða viðbótarprepa á föstu verðlagi í janúar 2018 fyrir 1988-2018.

Heimild: Ríkisskattstjóri eigin útreikningar.

Pegar hugað er að pessu kerfi í norrænum samanburði ber að nefna að skattkerfin á Norðurlöndunum eru ólík að pví leyti að sum eru með skattleysismörk og önnur hafa persónuafslátt. Einungis Danir og Ísland hafa persónuafslátt sem er fastur en hin hafa persónuafslátt og eða skattleysismörk sem ráðast af tekjum. Samspilið getur oft reynst flókið. Skattleysismörk á Íslandi eru og hafa verið hæst á Norðurlöndunum. Рað hefur pó dregið úr pessum mun á öllu tímabili staðgreiðslunnar og sérstaklega að undanförnu. Pegar prósentur og prep eru skoðuð hefur Island fæstan fjölda prepa og hæstu grunnprósentuna (fjármála- og efnahagsráðuneytið, 2019).

Líkt og kom fram í umfjölluninni hér fyrr verður raunskattskrið innan kerfisins ef viðmiðunarfjárhæðir fylgja launapróun ekki eftir. Á mynd 16 hefur próun vísitölu launa, skattleysismarka launpega og vísitölu neysluverðs verið upp á við frá árinu 1988. Eins og við sjáum fylgdust skattleysismörk og launavísitalan að par til 1993 en kaupmáttur launa hafði dregist saman á peim tíma. Árið 1993 taka laun að hækka umfram skattleysismörk. Síðan pá hefur raunskattbyrði framteljenda verið að aukast. Рað kemur heim og saman við próunina á mynd 9 par sem hlutur opinberra tekna eykst töluvert milli 1993 og 1994. Hafa ber í huga að skattbyrði allra innan kerfisins eykst en eins og áður kom fram eykst byrðin meira hjá peim tekjulægri.

29 Fyrir tekjuárið 2018 pýðir pað að við skattskyldar tekjur eftir framlag í lífeyrissjóð 239.533 fer ríkissjóður að fá tekjuskatt í sinn hlut en pá fer meðalskattbyrði framteljandans af skattskyldum tekjum yfir 14,44\%. Frá skattleysismörkum byrjar framteljandi að greiða skatt en sá skattur rennur allur til sveitarfélaga par til framangreindu tekjustigi er náð. Með hækkun útsvars hefur kostnaður ríkissjóðs vegna pessa vaxið verulega. 


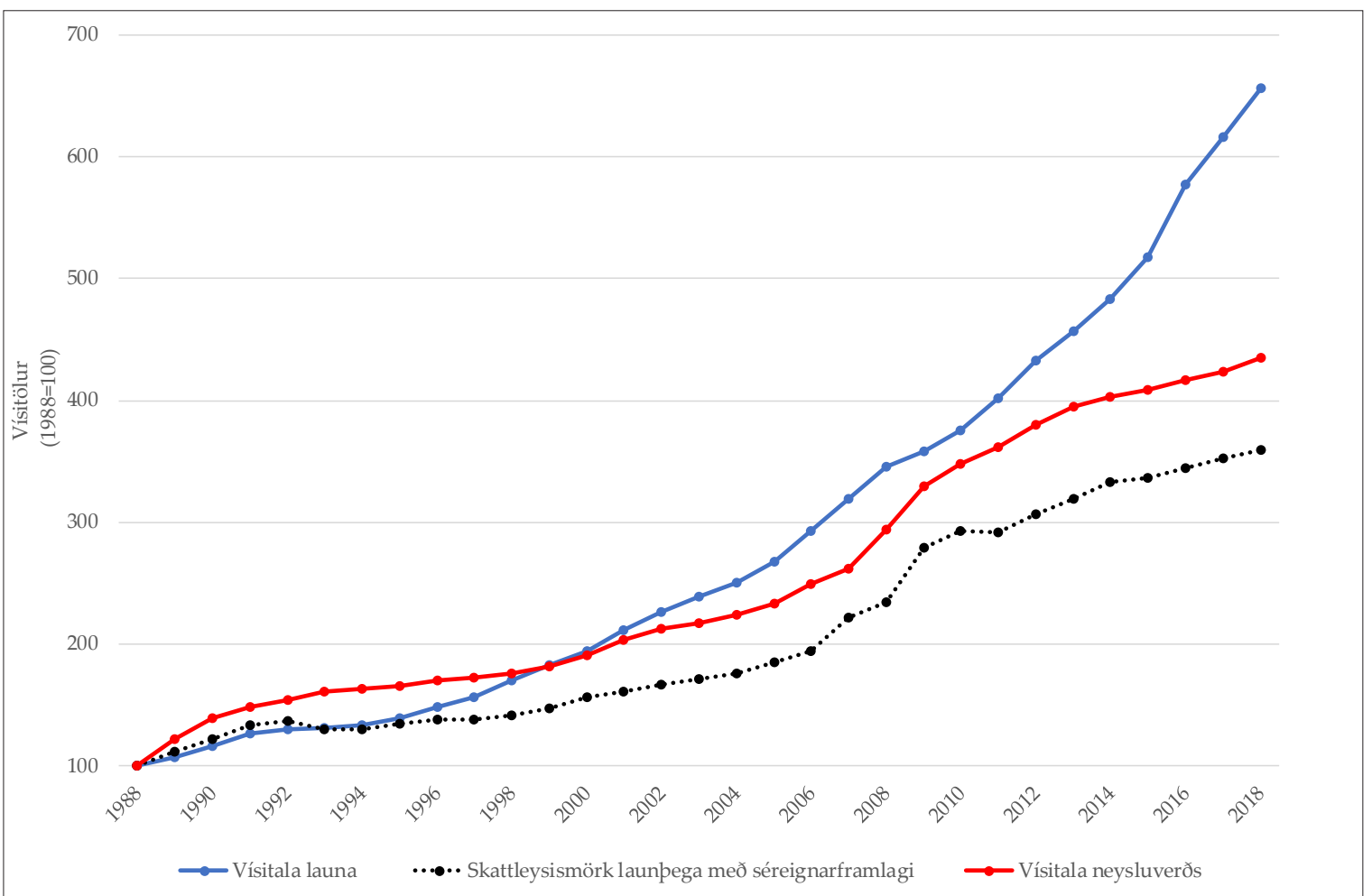

Mynd 16. Próun launa, skattleysismarka og verðlags tekjuárin 1988-2018. ${ }^{30}$

Heimild: Hagstofa Íslands, Ríkisskattstjóri og eigin útreikningar.

Hægt er að skipta tímabilinu á myndinni í tvennt og mismunandi árabil á seinni hluta tímabilsins og skoða heildarhækkun pessara priggja pátta sem fram koma á myndinni.

Tafla 4. Heildarhækkun skattleysismarka, verðlags og launa.

\begin{tabular}{lccccc}
\hline & $1988-2018$ & $1988-2003$ & $2003-2018$ & $2003-2010$ & $2010-2018$ \\
\hline Skattleysismörk \% & $259 \%$ & $71 \%$ & $110 \%$ & $71 \%$ & $23 \%$ \\
Verðlag \% & $335 \%$ & $117 \%$ & $100 \%$ & $60 \%$ & $25 \%$ \\
Laun \% & $556 \%$ & $139 \%$ & $175 \%$ & $57 \%$ & $75 \%$ \\
\hline Kaupmáttur launa \% & $51 \%$ & $10 \%$ & $37 \%$ & $-2 \%$ & $39 \%$ \\
\hline
\end{tabular}

Heimild: Hagstofa Íslands, Ríkisskattstjóri og eigin útreikningar.

Í töflu 4 er tímabili staðgreiðslu skipt í tvennt og síðan er seinna tímabilinu aftur skipt í tvennt. Pegar litið er yfir tímabilið í heild sést hvernig skattleysismörkin hafa ekki fylgt verðlagi. Líkt og áður hefur komið fram hefur persónuafslátturinn gert pað í mun ríkari mæli en skattleysismörkin enda eru pau samspil grunnprósentu, sem hefur verið að breytast, og persónuafsláttar. Raunskattskriðið á sér einkum stað á fyrri hluta tímabilsins. Á seinni hluta tímabilsins hækka skattleysismörk meira en verðlag sem mildar raunskattskriðið. Ef tímabilið er hlutað í sundur sjást áhrif sjálfvirku sveiflujöfnunarinnar glögglega. Frá 2003 og fram yfir efnahagsáfallið hækka laun minna en verðlag og á sama tíma hækka skattleysismörkin meira en verðlag. Við petta dregur hið opinbera úr skattbyrði en pá verður að nefna að á sama tíma og tekjuhliðin gaf eftir pá jukust útgjöldin og halli á rekstri hins opinbera með tilheyrandi skuldsetningu varð reyndin. Undir lok seinna tímabilsins, p.e. 2010-2018, voru skattleysismörkin og verðlag í nákvæmlega sama takti en kauplag

30 Vísitala launa er á upphafsgildi 100 í desember 1988 (upphaf framsetningar launavísitölu) en ársmeðaltöl eftir pað. Vísitala neysluverðs byggist á ársmeðaltali. 
hefur hækkað verulega að undanförnu og kaupmáttaraukningin er nú 39\% á pessu tímabili. Fyrirkomulag tengingar viðmiðunarfjárhæða eykur skattbyrðina sjálfkrafa líkt og áður hefur verið lýst. Engu að síður hefur petta reynst nauðsynlegt par sem uppsöfnun skulda hins opinbera kallar á að skuldir séu greiddar pegar betur árar. Pannig hefur hluti kaupmáttaraukningarinnar farið í pað að greiða niður skuldir. Að undanförnu hafa 10\% tekna ríkissjóðs farið í vaxtagreiðslur. Samkvæmt fjármálaáætlun fara skuldir hins opinbera undir 30\% viðmið laganna um opinber fjármál á tímabili núgildandi áætlunar sem nær til 2023 og um leið mun skuldastaðan ná svipuðu stigi og fyrir efnahagsáfallið 2008.

Pegar öðru viðbótarprepi var bætt við árið 2010 var ákveðið að öll viðbótarprep fylgdu vísitölu launa, en kjarasamningar og annað hafði áhrif par á. Persónuafsláttur fylgir hins vegar vísitölu neysluverðs eins og áður hefur verið vikið að.

Viðmið núverandi efra preps hafa hækkað um tæp 37\% frá janúar 2010 til janúar 2018 en verðlag á sama tíma um rúm 25\%, pað er 12 prósentustigum minna. Af pví leiðir að umtalað raunskattskrið hefur í ríkari mæli náð til tekna í neðsta skattprepi síðan 2010. Hér er um að ræða ákveðna mótsögn í kerfinu sem tekið var á í fjárlögum fyrir árið 2019 með tengingu tekjumarka efra preps við verðlagspróun með tímabundinni ráðstöfun.

Nokkrar vörður og framvindubrot hafa orðið í kerfinu á undangengnum árum sem vert er að halda til haga. Sumt hefur pegar verið nefnt en annað ekki:

- Tekjuárið 1994: Sérstakur 5\% tekjuskattur (hátekjuskattur) tekinn upp. Kveðið var á um að lífeyrisiðgjöld launpega yrðu frádráttarbær frá skattstofni tekjuskatts. Með pví urðu skattleysismörk launpega hærri en skattleysismörk bótapega. Jafnframt var grunnprepið hækkað um 0,35\% vegna lækkunar virðisaukaskatts á matvæli.

- Tekjuárið 1995: Ákveðið að lífeyrisiðgjöld launpega yrðu frádráttarbær frá skattstofni tekjuskatts. Með pví urðu skattleysismörk launpega hærri en skattleysismörk bótapega.

- Tekjuárið 1996: Sjálfvirkar verðuppfærslur felldar niður af nær öllum viðmiðunarfjárhæðum tekjuskattskerfisins.

- Tekjuárið 2004: Ákveðið að lækka álagningu í efra skattprepi í áföngum par til pað legðist af eftir tekjuárið 2005.

- Tekjuárið 2007: Persónuafsláttur bundinn við vísitölu neysluverðs.

- Tekjuárið 2010: Tveimur viðbótarprepum bætt við tekjuskattskerfið og pví urðu prepin alls prjú. Vísitölubinding persónuafsláttar var afnumin að nýju en próun hans hefur fylgt verðlagi, sem var lögfest 2012. Sérstakt útvarpsgjald var kynnt til sögunnar, sem lagt er á samhliða álagningu.

- Tekjuárið 2014: Miðprepið var lækkað úr 25,8\% í 25,3\%. Neðri prepamörk voru hækkuð um 20\% sem var 14 prósentustigum umfram lögboðna vísitöluhækkun.

- Tekjuárin 2016 og 2017: Miðprep lækkað í fyrri áfanga og fellt niður í síðari áfanga. Neðra prep var í tveimur áföngum lækkað í 22,5\%. Efra prep hést óbreytt í 31,8\%. 


\title{
4 Lífskjarasamningar og nýtt neðsta prep
}

Í yfirlýsingu ríkisstjórnarinnar frá 27. febrúar 2018 um aðgerðir í págu félagslegs stöðugleika í tilefni af mati á komandi kjarasamningum á almennum markaði er að finna áform um endurskoðun á tekjuskattskerfi einstaklinga. Par segir nánar tiltekið:

\begin{abstract}
„Hafin verður endurskoðun á tekjuskattskerfinu með áherslu á lækkun skattbyrði og mögulegar breytingar á fyrirkomulagi persónuafsláttar og samspili við bótakerfi sem ætlað er að styðja við tekjulægri hópa (lágtekjur og lægri millitekjur).... Dessi vinna verður undir forystu fjármála- og efnahagsráduneytis í samstarfi við samtök launpega í poí skyni að sem breiðust samstaða geti nádst um áherslur og endanlegar breytingar. Ætlunin er að ljúka pessari vinnu á haustmánuðum 2018 ádur en fjárlög ársins 2019 verða afgreidd."
\end{abstract}

Í fjármálaáætlun ríkisstjórnarinnar um opinber fjármál fyrir árin 2019-2023 kemur fram að heildarendurskoðun á tekjuskattskerfinu samhliða endurskoðun bótakerfa verði gerð með pað að leiðarljósi að auka sérstaklega ráðstöfunartekjur lágtekjuhópa og peirra sem eru með lægri millitekjur. Pá segir að miðað sé við að pær breytingar sem endurskoðunin leiðir af sér geti jafngilt eins prósentustigs lækkun neðra tekjuskattspreps, eða 14 ma.kr. lækkun á skattbyrði fjölskyldna á ársgrundvelli, sem verði lögfest sem fyrst og komi til framkvæmda á kjörtímabilinu.

Skipuð var stýrinefnd og sérfræðingahópur í lok júní 2018. Höfundur var formaður sérfræðingahópsins og skýrsla hópsins er yfirgripsmikil og varðar fleiri pætti en varðar breytingar á skattkerfi tekjuskatts (Fjármálaráðuneytið, 2019).

\subsection{Próun marka skattkerfis tekjujöfnun og sjálfvirk hagstjórn}

Áður hefur verið fjallað um hvernig ákvörðun um próun persónuafsláttar og par með skattleysismarka og marka efra skattpreps yfir tiltekinn tíma hefur áhrif á tekjujöfnun og sveiflujöfnun hins opinbera. Í núverandi skattkerfi er persónuafslætti og par með skattleysismörkum breytt í samræmi við próun vísitölu neysluverðs en mörk efra skattpreps hafa hingað til breyst í samræmi við próun launavísitölu. Pessi aðferð hefur áhrif á tekjujöfnun kerfisins en einnig á hagstjórn pess. Breyting í pá átt að mörk efra preps fari einnig eftir vísitölu neysluverðs hefur áhrif á báđa pessa pætti og eykur einnig virkni sjálfvirkrar hagstjórnar.

Pegar viðmiðunarfjárhæðir skattkerfis hækka hægar en laun pyngist skattbyrði par eð framteljendur færast pá upp eftir hinum hallandi ferli skattbyrðar. Há grunnprósenta, p.e.a.s. fyrsta skattprepið, og mikið vægi skattleysismarka gerir pað að verkum að skattbyrði eykst mest hjá peim sem lægri launin hafa pótt skattbyrði allra aukist. Áhrifin verða ójafnari eftir pví sem prepin eru færri og munur á tröppum er skarpari.

Раð fyrirkomulag sem pyngir skattbyrði pegar laun hækka umfram verðlag og léttir skattbyrði pegar laun halda ekki í við verðlagspróun er öflugt tæki við hagstjórn. Раð felur í sér að skattbyrði eykst á penslutímum og minnkar á tímum samdráttar. Stjórnvöld stíga á bremsuna á pensluskeiðum og gefa í á samdráttarskeiðum án pess að purfa að taka nokkra ákvörðun par um. Petta er gott dæmi um pað sem kallast sjálfvirkir sveiflujafnarar. Hægt er að sjá petta með pví að skoða meðalskattbyrði yfir tíma og bera próunina saman við breytingu kaupmáttar launa.

Samanburður við aðrar Norðurlandapjóðir á skattbyrði ólíkra hópa sýnir að par hefur hún nokkurn veginn staðið í stað frá 2010 (OECD, 2018). Рað pýðir að launapróun og viðmiðunarfjárhæðir hafa haldist í hendur að pví gefnu að jaðarskattar hafi staðið í stað. Í pessu samhengi verður pó að líta til almennt fyrirkomulags kjarasamninga annars staðar á Norðurlöndunum sem byggir á pví að framleiðnipróun samkeppnisgreina liggi til grundvallar kjarabótum á almennum vinnumarkaði. Próist laun í samræmi við verðlag og fram- 
leiðni verður ekki sama pörf á virkri hagstjórn og pað verður heldur ekki vandamál að mörk prepa, afslættir og frádráttarliðir fylgi launapróun. Hér á landi hefur raunin verið önnur og próun launa oft verið umfram panpol efnahagslífsins, breytingu framleiðni og viðskiptakjara.

Раð væri pví óheppileg ráðstöfun að taka virka hagstjórn úr sambandi eins og upptaka tengingar við laun hefði í för með sér. Um leið verður að hafa í huga að núverandi fyrirkomulag án reglulegrar uppfærslu skattleysismarka dregur smám saman úr jöfnunareiginleika skattkerfisins. Spurningin sem parf að svara hér lýtur að pví hvers konar uppfærsla prepa, persónuafsláttar og par með skattleysismarka uppfyllir pað markmið að skattkerfið feli í sér tekjujöfnun en stuðli jafnframt að virkri sveiflujöfnun við hagstjórn í ljósi pess ójafnvægis sem oft skapast á vinnumarkaði hér á landi.

Í pessu samhengi var pví af hálfu sérfræðingahópsins lögð fram tillaga um að skattleysismörk og tekjumörk efra skattpreps fylgi próun samanlagðra breytinga á vísitölu neysluverðs og próun framleiðni. Slík tenging tryggir að tekjujöfnunareiginleikar skattkerfis haldist yfir tíma án pess að skerða hagstjórnaráhrif pess. Pegar laun próast í samræmi við pað sem hagkerfið getur staðið undir pá ætti skattbyrðin að haldast óbreytt. Ef laun hækka hins vegar meira en sem nemur samtölu hlutfallslegrar hækkunar verðlags og framleiðni pá eykst skattbyrði vegna pess að tekjumörkin breytast ekki jafn mikið og laun. Eiginleikum virkrar hagstjórnar verður pannig viðhaldið um leið og raunskattskriðið verður gert kostnaðarsamara fyrir launafólk en ef viðmiðunarfjárhæðir miðuðust við launapróun. Um leið koma ýmis álitamál upp í pessu samhengi sem líta parf til og fjallað er um í kaflanum.

Nokkur munur er milli ára á mati á framleiðni eftir pví hvaða aðferð er notuð. Munurinn er langmestur árið 2009, árið eftir efnahagsáfallið, en er einnig talsverður árið 2017. Sé litið yfir lengra tímabil er pó ekki ýkja mikill munur á peim mælikvörðum sem skoðaðir eru. Yfir lengri tíma próast framleiðni og kaupmáttur launa eins. Í ljósi peirra sveiflna sem birtast í framleiðni er hér lögð fram sú tillaga að priggja ára hreyfanlegt meðaltal sé lagt til grundvallar uppfærslu viðmiðunarfjárhæða.

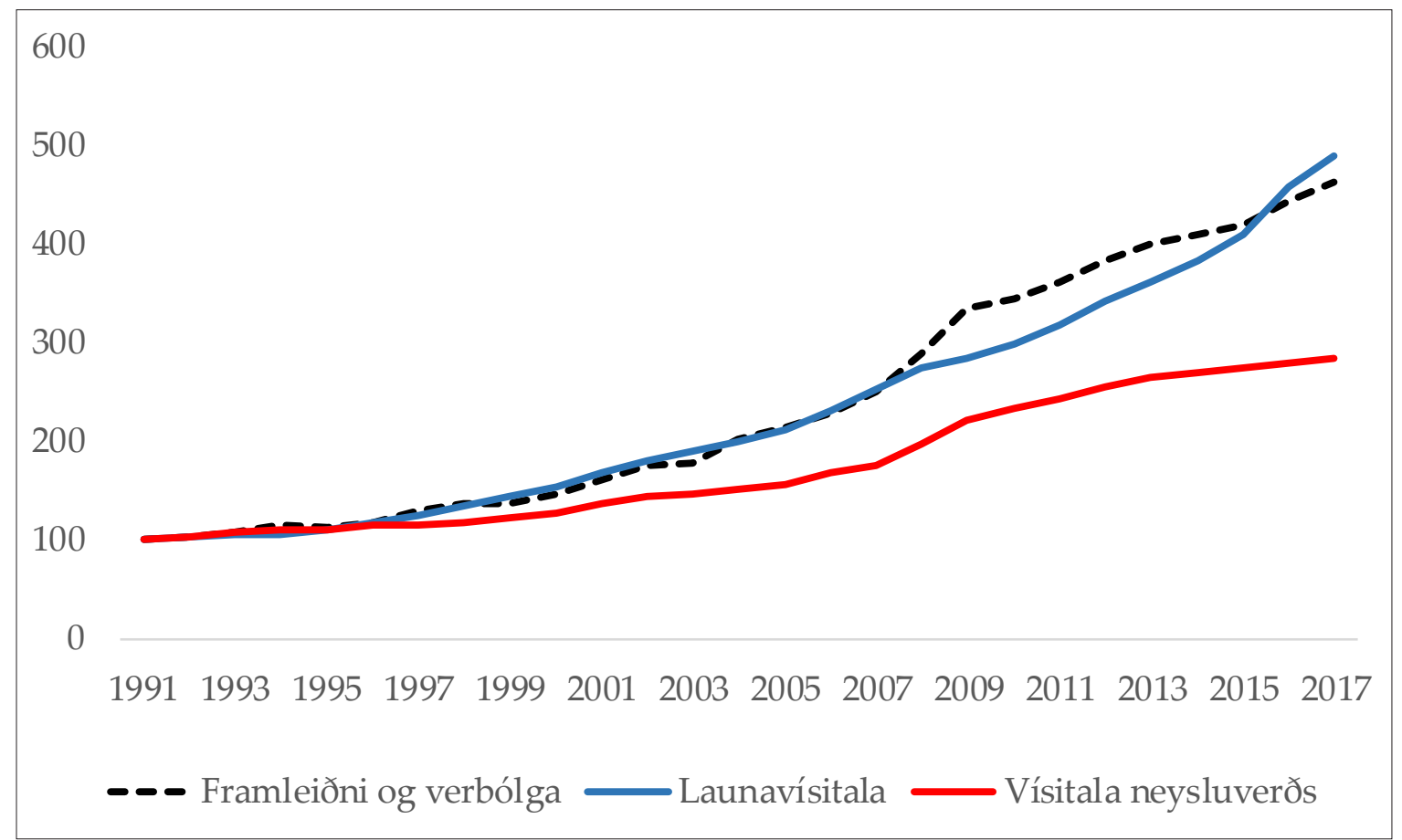

Mynd 17 Próun framleiðni í QMM Seðlabanka Íslands og próun kauplags og verðlags Heimild: Seðlabanki Íslands og Hagstofa Íslands 
Sveiflur í framleiðnipróun geta verið svo miklar að breyting einstaks árs hafi töluverð áhrif á priggja ára meðaltal og gangi á svig við sjónarmið um virka hagstjórn. Pess vegna er hér ekki lögð til sjálfvirk uppfærsla á viðmiðunarfjárhæðum heldur verði búið til viðmið, nokkurs konar akkeri, sem hægt verði að miða við bæði til skamms og langs tíma. Stjórnvöld leggi petta viðmið síðan til grundvallar, pað verði pekkt og ef önnur sjónarmið eiga við um uppfærslu séu pau rökstudd og ákvörðun tekin með gagnsæi að leiðarljósi.

\subsection{Sviðsmyndir breytinga í núverandi kerfi}

Verkefni sérfræðingahóps og stýrinefndar var að beina fjármagni sem sett var til hliðar í fjármálaáætlun 2019-2023 að̀ tekjulægri einstaklingum og fjölskyldum. Áherslan í pessu samhengi var pví að skoða próun skattbyrði og samspil hennar við stýritæki kerfisins sem eru aðallega grunnprósenta og persónuafsláttur. Keyrslur sviðsmynda voru síðan keyrðar í nýju líkani fjármála- og efnahagsráđuneytisins. Hér er leitast við að hafa greininguna eigindlega fremur en megindlega, engu að síður byggist greiningin á megindlegri niðurstöðu keyrslna í líkaninu.

Almennt í núverandi kerfi (án pess að skilgreina nýtt prep) er hægt að sjá áhrif breytinga á grundvelli fjögurra sviðsmynda sem eru sýndar í eftirfarandi töflu.

Tafla 5. Sviðsmyndir í núverandi kerfi tekjuskatts.

\begin{tabular}{cccc}
\hline Sviðsmynd & Skattprósenta ( $(\tau)$ & Persónuafsláttur $(c)$ & Skattleysismörk $(A)$ \\
\hline 1. & $\downarrow$ & Óbreytt & $\uparrow$ \\
2. & $\downarrow$ & $\downarrow$ & Óbreytt \\
3. & $\downarrow$ & $\uparrow$ & $\uparrow$ \\
4. & Óbreytt & $\uparrow$ & $\uparrow$ \\
\hline
\end{tabular}

Mikilvægt er að sjá hvernig áhrif pessara sviðsmynda birtast með hliðsjón af skattbyrðinni. Á mynd 18 er hinn hefðbundni skattbyrðisferill einstaklings í kerfi staðgreiðslu sem og jaðarskattur í hverju prepi.

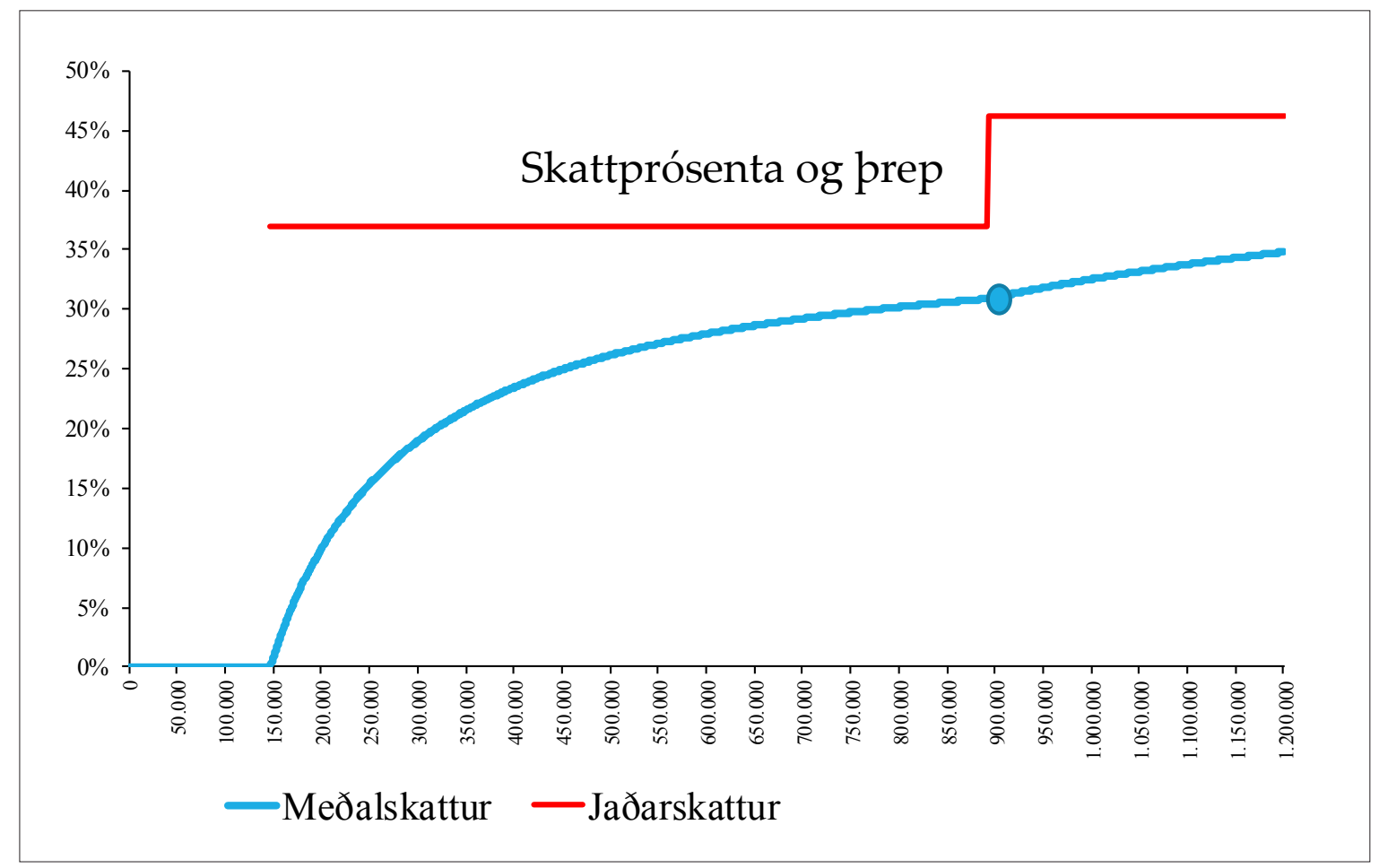

Mynd 18. Skattbyrði einstaklings í tekjuskatti (mánaðarlegar skattskyldar tekjur). 
Allar útfærslur sem hér er lýst hliðra bláa ferli meðalskatts (skattbyrði) til hægri og hinn nýi ferill birtist lóðrétt undir eldri ferlinum. Við breytinguna dregur úr skattbyrði við hvert tekjustig en í mismiklum mæli pó eftir sviðsmyndum.

Lækkun skattprósentu ein og sér í fyrstu sviðsmynd hækkar skattleysismörk og minnkar skattbyrði allra um sama prósentustig. Pessi sviðmynd er sýnd á mynd 19. Við lækkun prósentunnar við óbreyttan persónuafslátt hækka skattleysismörkin og alls staðar er sama fjarlægð í lóðréttu tilliti milli nýja græna ferilsins og gamla bláa ferilsins. ${ }^{31}$ Pessi nálgun svarar til forsendu stjórnarsáttmála en ráđstöfunin dregur úr jöfnun um leið og hún eykur hvata til vinnu. Prósentutala lækkunar er í krónutölu hærri hjá peim sem hafa hærri laun. Pessi áhrif eru pó milduð af pví að 46,24\% lækkar ekki.

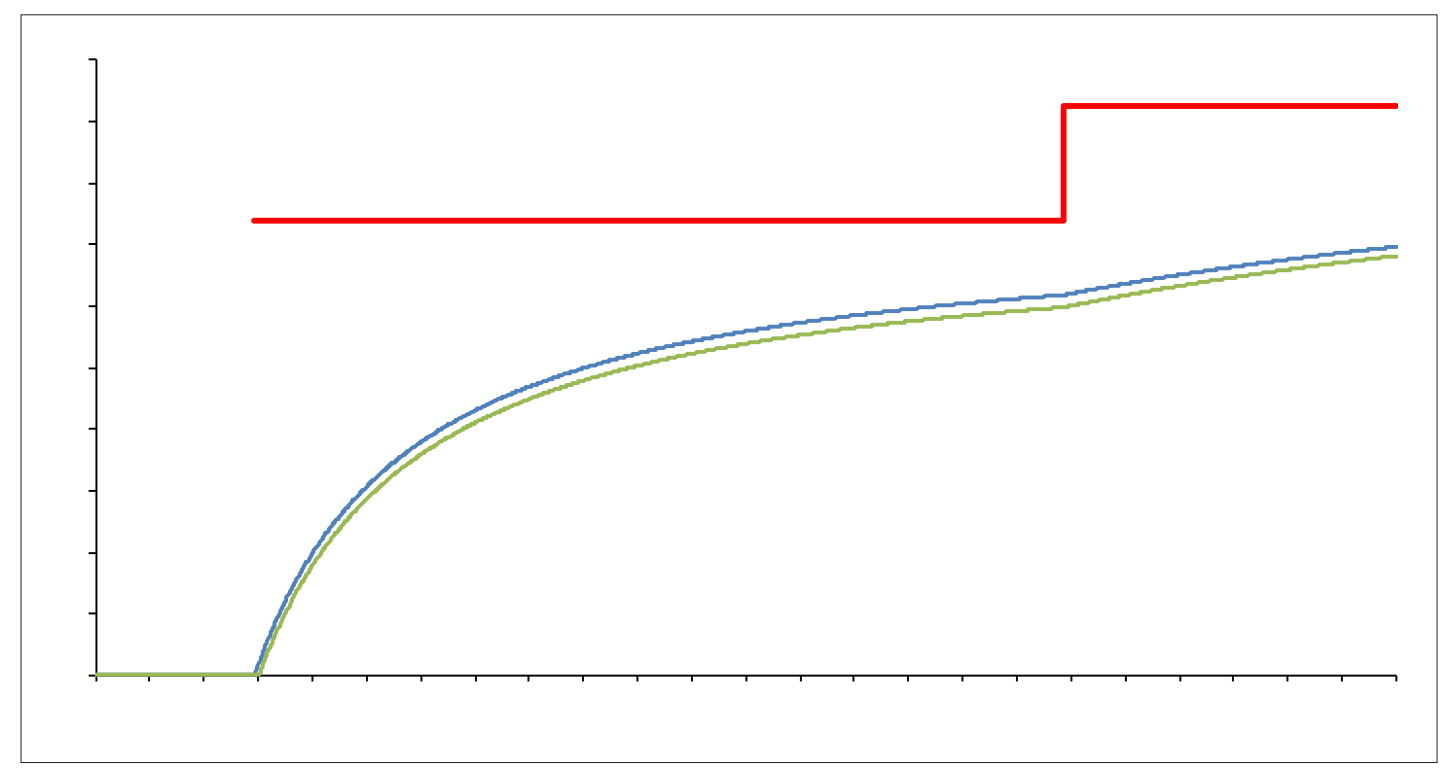

Mynd 19. Lækkun prósentustigs í neðra prepi en efra prep óbreytt (sviðsmynd eitt).

Í annarri sviðsmynd er skattprósentan lækkuð og persónuafslátturinn um leið pannig að skattleysismörkum er haldið óbreyttum fyrir gefna minnkun í tekjuöflun hins opinbera. Pessi nálgun gengur hvað lengst í að auka hvata til vinnu en gengur um leið lengst gegn jöfnuninni í núverandi tveggja prepa kerfi. Hún er ekki til frekari skoðunar í sviðsmynd tveggja prepa kerfis.

31 Nema við efri mörk tekna, í hátekjuprepinu, pví að prósentan lækkar ekki sem gerir pað að verkum að við háar tekjur falla ferlarnir næstum saman. 


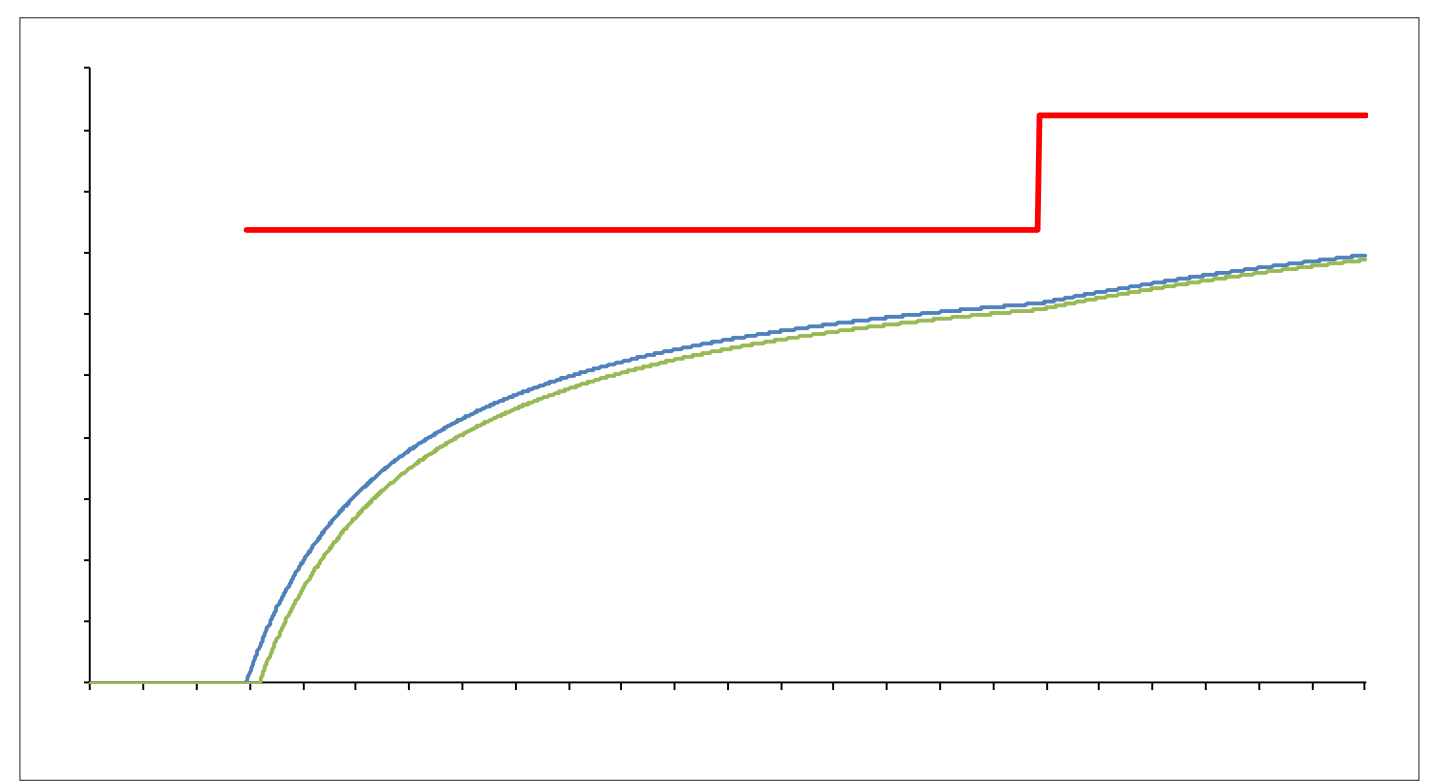

Mynd 20. Hækkun persónuafsláttar (sviðsmynd fjögur).

Fjórða sviðsmyndin sem er sýnd á mynd 20 byggist á pví að skattprósentu er haldið óbreyttri en ráðstöfunin beinist fyrst og fremst að hækkun persónuafsláttar. Persónuafsláttur sem er krónutala á hvern framteljanda vegur hlutfallslega mest hjá peim sem lægst hafa launin eins og fyrri umfjöllun gefur til kynna. Ferillinn hliðrast til hægri og mest við lágar tekjur. Eftir pví sem tekjur aukast dregur úr lóðréttri fjarlægð milli upphaflega ferils skattbyrðar (pess bláa) og nýja ferils skattbyrðar (pess græna). Áhrifin fjara út við háar tekjur. Hækkun persónuafsláttar er hins vegar dýr aðgerð. Púsund króna hækkun persónuafsláttar á mánuði kostar til að mynda u.p.b. 3 ma.kr. á ári. Pessi aðgerð hefur engin jaðaráhrif og par af leiðandi engin áhrif á hvata til vinnu.

Fyrir gefna fjárhæð í minnkaðri tekjuöflun eru sviðsmyndir eitt, tvö og fjögur með gjörólíka útkomu á pví hverjir njóta aðallega skattalækkunar. Hækkun persónuafsláttar gefur öllum fasta krónutölu og vegur hlutfallslega mest hjá peim sem hafa lágar tekjur. Lækkun prósentunnar gefur peim sem hæstar hafa tekjurnar hæstu krónutölu enda pótt hlutfallstala ávinnings sé hin sama fyrir alla. ${ }^{32}$

Priðja sviðsmyndin fer bil beggja og hefur bæði áhrif á jöfnuð og hvata í skattkerfinu. Miðað við pá fjárhæð sem er til ráđstöfunar er slík aðgerð máttminni fyrir jöfnuð og hvataáhrif en hinar enda brúar hún bil beggja sjónarmiðanna og dreifir kröftunum miðað við gefna fjárhæð sem er til ráđstöfunar.

Leiðarljós fyrri umfjöllunar hér er sú staðreynd að prósenta skattkerfisins við skattleysismörkin er há í norrænum samanburði og skattleysismörkin líka. Skattleysismörkin hafa pó gefið eftir frá upptöku staðgreiðslunnar og hafa nálgast pað sem kalla má „norrænt" stig. Grunnprósenta skattkerfisins er nú um stundir u.p.b. 2 prósentustigum hærri en hún var við upptöku staðgreiðslunnar. Prósentan hækkaði til að byrja með á níunda áratugnum en síðan var leitast við að lækka hana en hún hefur pó aldrei náð pví sem hún var við upphaf staðgreiðslunnar. Tvennt stendur hér upp úr í pessari umræðu. Annars vegar er í kerfinu minni jöfnun en áður og hins vegar há grunnprósenta.

Almennt er hægt að hækka persónuafslátt til að auka jöfnun skattkerfisins eins og komið hefur fram en pað er dýr ráðstöfun, hækkar skattleysismörk og færir okkur fjær hinni norrænu nálgun. Önnur leið til pess að auka jöfnun, en ná á sama tíma fram ákjósanlegum áhrifum er snertir hvata vinnuframboðs, er að búa til nýtt neðsta prep. Slíkt prep drægi úr vægi persónuafsláttar fyrir jöfnunina sem pá yrði í ríkari mæli en áđur borin af prepum kerfisins. Aukinheldur er mun ódýrara að hnika til prósentu í pví prepi en grunnprósentu 
núverandi kerfis. Pannig reynist unnt að ná meiri lækkun prósentu hins nýja preps að gefnum fjárhæðum til lækkunar skatta. Lág prósenta í neðsta prepi hefur líka bein áhrif í samspili skatta- og bótakerfa og minnkar jaðaráhrif peirra. Рað telst eftirsóknarvert.

Að lokum skal bent á að virk hagstjórn eykur skattbyrðina mest við tekjustig ofan við mörk prepa, t.a.m. tekjustig rétt ofan skattleysismarka líkt og gerst hefur undanfarin ár. Í skýrslu sérfræðingahópsins er lagt til að dregið verði úr virkri hagstjórn í gegnum skattkerfið með tengingu skattkerfismarka við verðlag og framleiðni. Slík ráðstöfun felur engu að síður í sér sjálfvirka sveiflujöfnun en í minni mæli en áður. Í pessu samhengi skiptir máli að peim mun fleiri sem mörk prepa eru pví jafnara leggst hagstjórnin á skattgreiðendur. Hér parf pó að feta ákveðið einstigi pví að peim mun fleiri sem prepin eru pví flóknara verður kerfið og framkvæmd pess.

Ókostur aðgerðarinnar sem hér hefur verið lýst með nýju prepi er sá að hvatar aukins vinnuframlags verða einungis í peim hluta tekjudreifingarinnar sem verður fyrir áhrifum breyttra jaðarskatta, fyrir hina með hærri tekjur felur breytingin í sér minni skattbyrði án jaðaráhrifa og líkist pannig peim áhrifum sem hækkun persónuafsláttar hefur.

Sérfræðingahópur og stýrinefnd litu svo á að nýtt lægra prep félli vel að lausn pess verkefnis sem lagt var upp með að leysa og skoðuðu í kjölfarið áhrif upptöku nýs lægra preps. Áhrif pess á skattbyrði eru sýnd í formi punktalínunnar á mynd 21. Fylltu punktarnir tákna pá bugðurnar í skattbyrðinni par sem skattbyrðin vex hraðar í kjölfar pess að tekjur fara yfir mörk. Рað er líka bugða á ferlinum við skattleysismörkin og skattleysismörkin hækka við óbreyttan persónuafslátt.

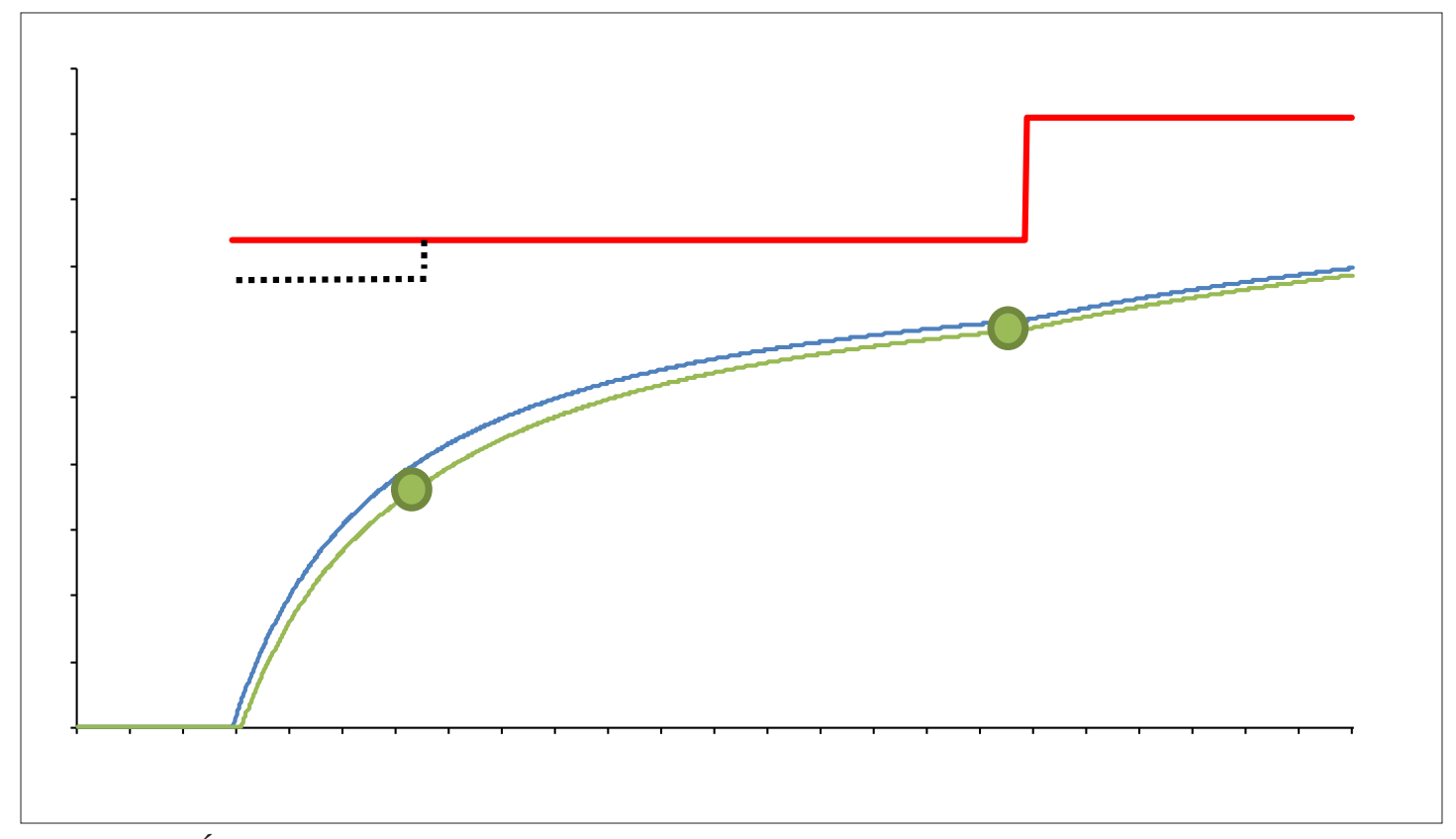

Mynd 21. Áhrif nýs neðra preps á skattbyrði.

Útfærslumöguleikarnir hér eru í anda sviðsmynda eitt til prjú. Á sviðsmyndum sem nefndar voru eitt og tvö er nýtt neðsta prep, búið að lækka skattprósentu pess og persónuafsláttur óbreyttur eða skattleysismörk. Á priðju sviðsmyndinni er búið að lækka bæði prósentu með nýju prepi og hækka persónuafslátt en aðferðin líður fyrir pað að gefin fjárhæð skattalækkunar dregur hratt úr möguleikum á prósentulækkun par eð breyting á persónuafslætti er dýr. Hér verður pví einblínt á sviðsmyndir eitt og tvö.

Hér á eftir fara tvær myndir sem eru stilltar pannig af að pær endurspegla jafngildar aðgerðir hvað tekjuöflun snertir. Á fyrri myndinni hefur verið búið til nýtt lægra prep en persónuafslættinum er haldið óbreyttum. Á seinni myndinni er sams konar aðgerð, p.e. nýtt lægra prep, en par er skattleysismörkum haldið óbreyttum með lækkun persónuafsláttar. Seinni myndin sýnir að meiri prósentulækkun næst en á fyrri myndinni og að við 
efri mörk hins neðra preps verður fjarlægðin frá upphaflega ferli skattbyrðar meiri, p.e. skattbyrði minnkar meira við mörkin. Tekjustig efri marka hins fyrsta preps skiptir miklu um áhrifin og um leið er dýrt að hnika peim hærra. Ef mörkin eru staðsett í kryppugildi tekjudreifingarinnar, p.e.a.s. par sem flestir eru, mun fjöldinn njóta minni skattbyrðar í ríkari mæli en ella. Aftur á móti minnkar skattbyrðin ekki eins mikið hjá peim sem eru fyrir neðan mörkin og eru líklegir til að vera í hlutastarfi fremur en í fullu starfi, séu mörkin rétt stillt.

Раð sem næst með lækkun persónuafsláttar, sem miðar að pví að halda skattleysismörkum föstum, er myndarlegri prósentulækkun á nýju prepi. Jöfnunin birtist pá í enn ríkari mæli en ella í gegnum tröppur skattkerfisins sem verða krappari en annars. Hlutur persónuafsláttar í jöfnuninni gefur pá eftir á móti. Með pessu móti er um leið leitast við hámarka jákvæð hvataáhrif íhlutunarinnar á fullvinnandi einstaklinga með lágar tekjur og bótapega.

Rík krafa hefur hingað til verið að hækka persónuafslátt og pví kann að hljóma mótsagnarkennt að hér skuli lögð fram tillaga um lækkun hans. Í pessu samhengi parf að hafa í huga að almennt í viðskiptum er horft til afsláttar í ljósi pess verðs sem verið er að greiða. Skattprósentan í pessu samhengi endurspeglar pá verðið en verð og afsláttur saman ákvarða hagkvæm kaup. Sama á við um persónuafslátt og prósentur skattkerfis. Ekki er eins pörf fyrir persónuafslátt pegar skattprósenta er lág. Almennt stangast pað pó á við sjónarmið um jöfnun en hér er aftur á móti lögð til sú ráðstöfun að prep skattkerfisins styðji jöfnunina í ríkari mæli en áður um leið og dregið er úr vægi persónuafsláttar. Jöfnunin kemur pá í ríkari mæli gegnum tröppurnar og pær verða krappari fyrir vikið. Af pessari ráðstöfun eykst skattbyrði ekki hjá neinum en ráðstöfuninni er í ríkari mæli beint að fullvinnandi fólki á vinnumarkaði og bótapegum á fullum bótum. Lækkun skattprósentunnar verður meiri fyrir vikið líkt og samanburður á mynd 22 og 23 gefur til kynna.

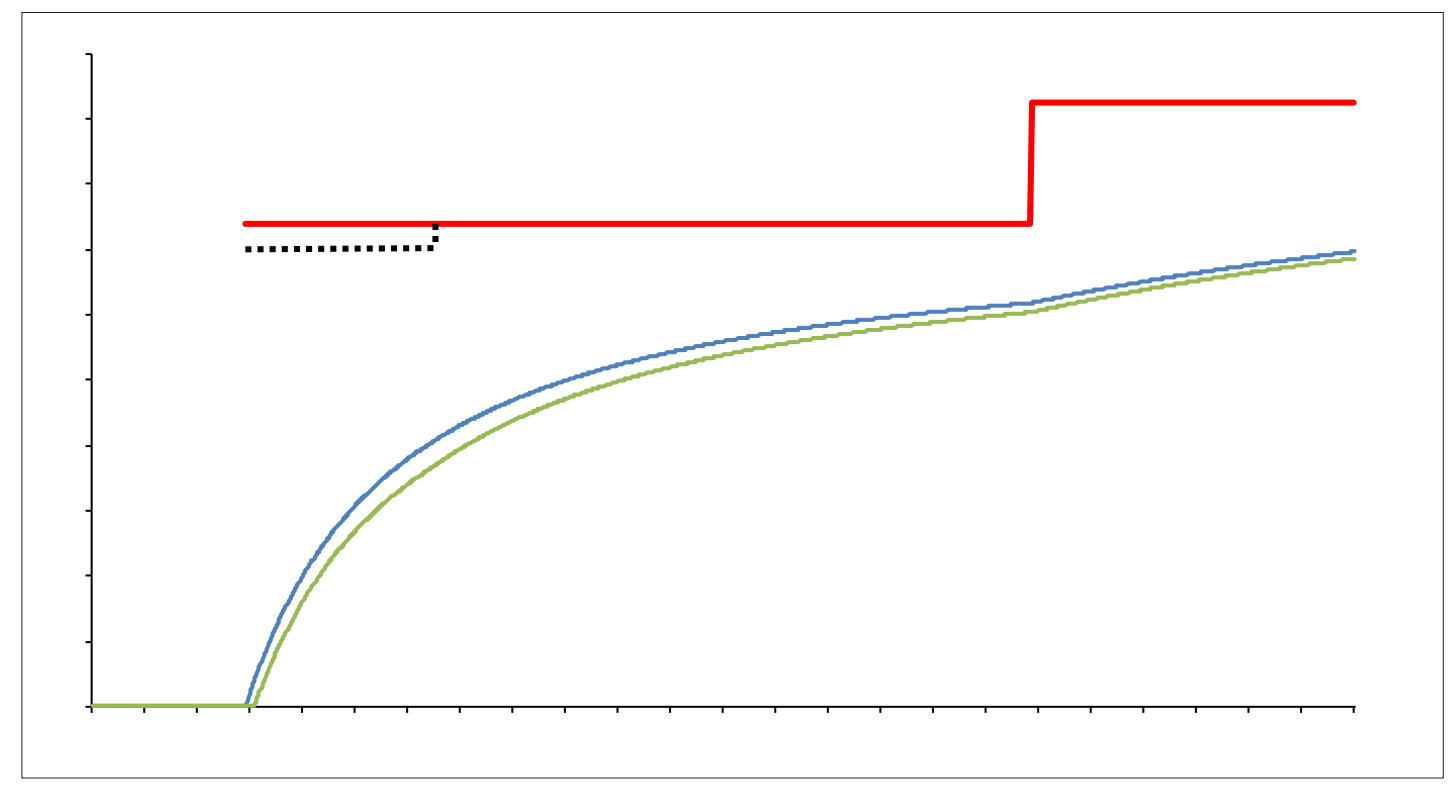

Mynd 22. Nýtt neðra prep með óbreyttum persónuafslætti. 


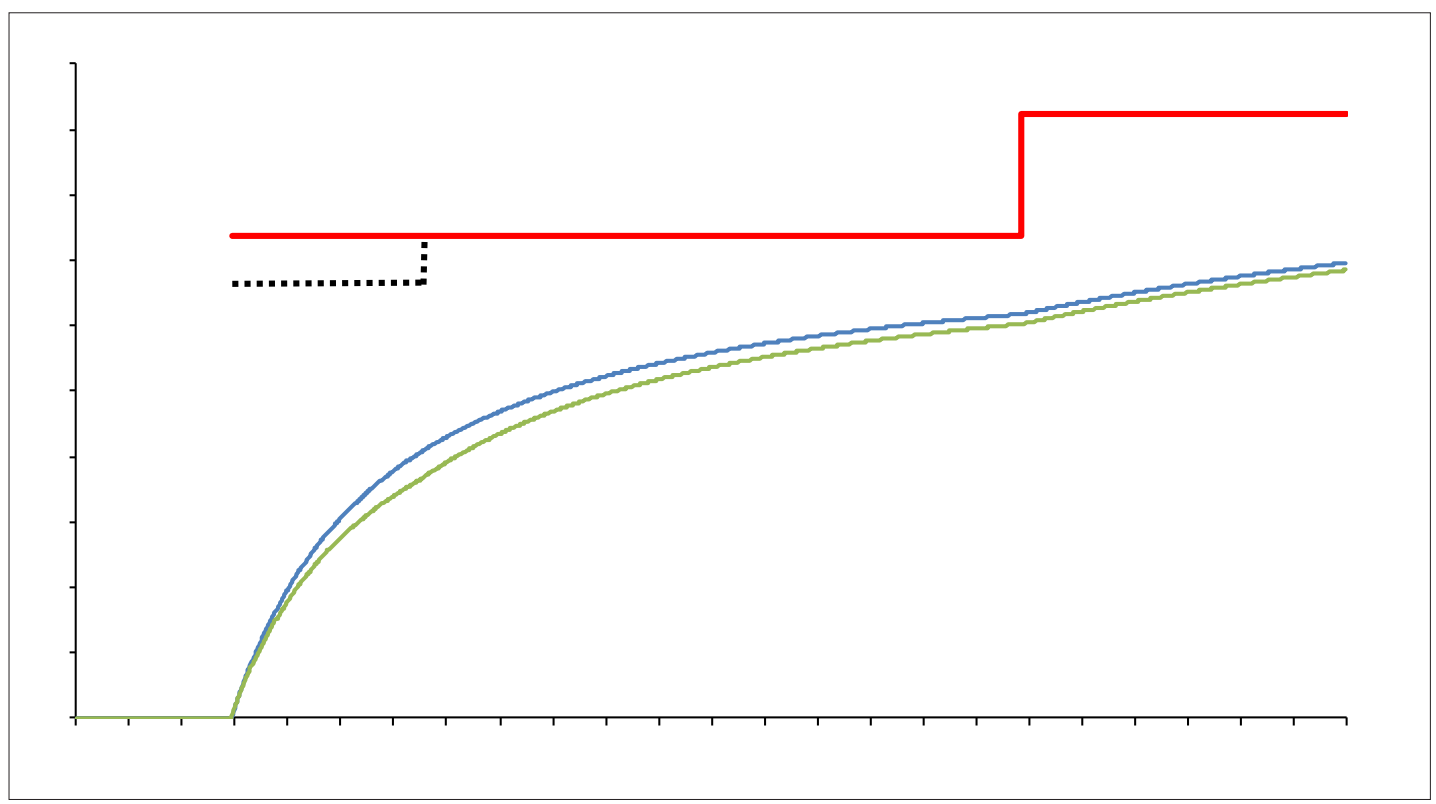

Mynd 23. Nýtt neðra prep með óbreyttum skattleysismörkum.

\section{3 Útfærsla stjórnvalda og áhrif á jöfnun}

Samráð stjórnvalda og aðila vinnumarkaðarins leiddi á endanum til útspils stjórnvalda í aðdraganda kjarasamninga á almennum vinnumarkaði á vormánuðum 2019. Hvað varðar breytingar á skattkerfinu birtast niðurstöður pessa útspils í fjárlagafrumvarpi fyrir árið 2020. Samkvæmt tillögum í fjárlagafrumvarpi verður nýtt neðsta prep innleitt á árinu 2020 og prepamörkin verða 330.225 á verðlagi ársins 2019. Neðsta prósentan lækkar úr 36,94\% í 35,04\% en millitekjuprósentan hækkar úr 36,94\% i 37,19\%. Efsta prósentan verður óbreytt. Árið 2021 munu tillögurnar hafa komið að fullu fram og grunnprósentan verður 31,44\%, miðjuprósentan 37,94\% og efsta prepið óbreytt 46,24\%. Persónuafsláttur verður lækkaður meðan á aðlöguninni stendur pannig að skattleysismörk haldist föst í kaupmætti. Til viðbótar taka mörk prepa og persónuafsláttur á tímabilinu mið af breytingum verðlags. Árið 2021 verður persónuafslátturinn orðinn 48.042 kr. á mánuði miðað við núverandi verðlag.

Árið 2022 er fyrirhugað að nýtt kerfi uppfærslu persónuafsláttar og mörkum prepa taki mið af af próun verðlags og framleiðni líkt og áður hefur verið lýst. Hér á eftir er mynd sem lýsir teygnistuðli ráðstöfunartekna fyrir og eftir breytingu. Annars vegar lýsir myndin hvernig jöfnunaráhrif kerfisins væru í dag ef persónuafsláttur hefði uppfærst um verðlagspróun um síðustu áramót (hann var hækkaður um 1\% umfram próun verðlag) og efri mörkin hefðu próast um vísitölu launa. Hins vegar lýsir myndin jöfnunaráhrifum kerfisins árið 2021 einnig á verðlagi dagsins í dag, par sem búið er að hækka persónuafsláttinn um 1\%, lækka hann svo með lækkun grunnprósentunnar til að skattleysismörkin haldist föst miðað við pað sem nú er. Pá verður ennfremur lokið við að innleiða að fullu lækkun grunnprósentu í 31,44\%, miðprósentu 37,94\% meðan efstu prósentu er haldið óbreytt við 46,24 en með lægri tekjumörkum efsta preps en áður pví kaupmáttaraukning kemur ekki inn í próun pess eins og hún hefði gert í núverandi kerfi. $x$-ásinn vísar til skattskyldra tekna á verðlagi 2019. 


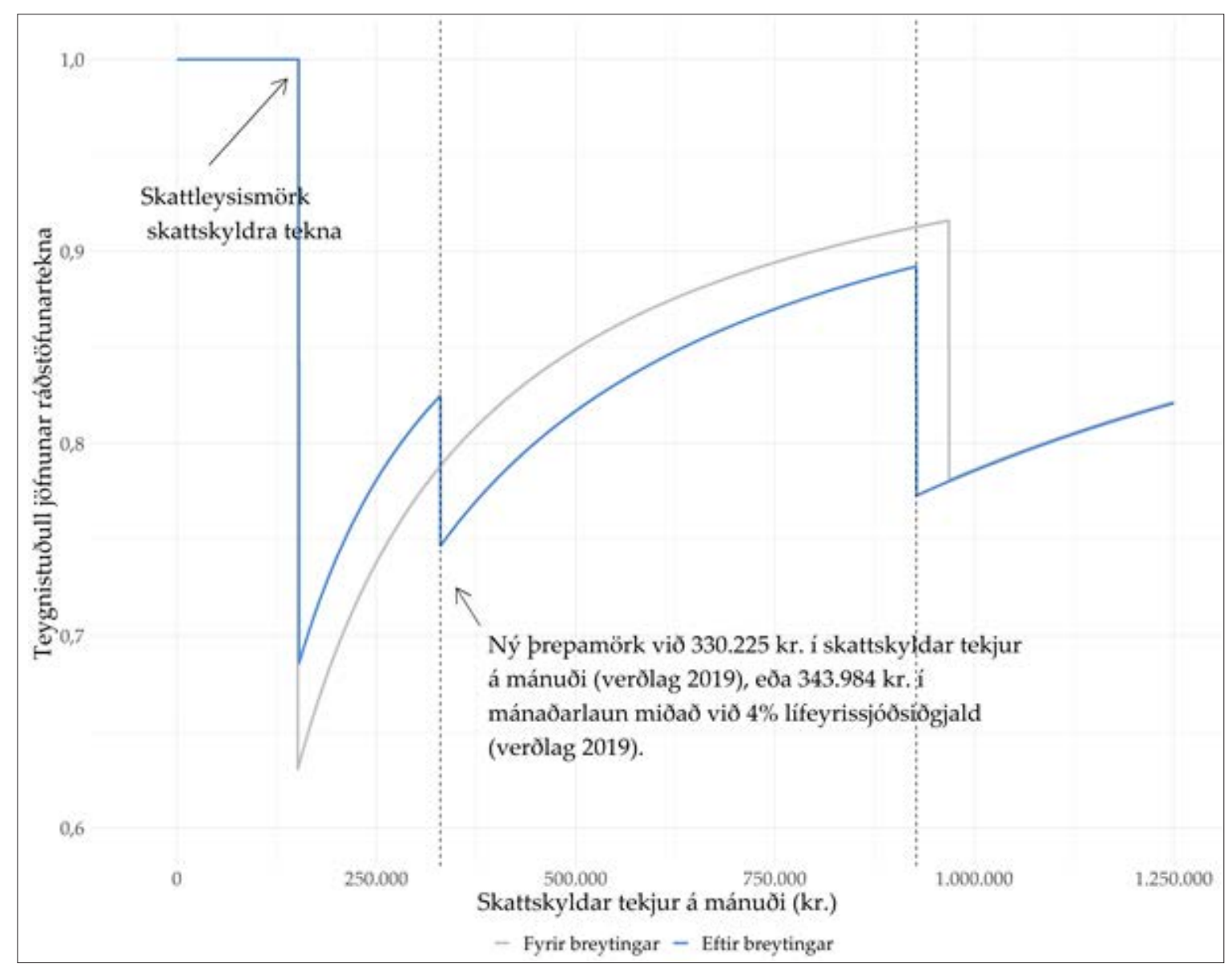

Mynd 24 Teygnistuðull jöfnunar ráđstöfunartekna, $\eta_{e}(w(1-p)) 2019$ í núverandi kerfis án breytinga og 2021 eftir breytingar

Heimild: Fjármála- og efnahagsráđuneytið

Mynd 24 sýnir með samanburði á blálitaða og grálitaða ferlinum hvernig kerfisbreytingin dregur úr jöfnuði í fyrsta prepi p.e. allir í lægri tekjum eru að fá auknar ráðstöfunartekjur með lægri grunnprósentu og teygnin vex. Peir sem eru í milliprepinu fá í sinni hlut lækkaða krónutölu vegna breytingar á prósentu í neðsta prepi en standa á móti frammi fyrir hækkun prósentu í milliprepinu. Báðir pessir pættir leggjast á eitt til að auka jöfnun kerfisins í millitekjuprepi og teygnistuðull lækkar. I efsta prepinu vex jöfnun á stuttu bili sem er til komið vegna pess að í hinu nýja kerfi eru efstu prepamörkin ekki uppfærð um vísitölu launa eins og áður. Peir sem hefðu verið í efsta prepi án breytinganna standa frammi fyrir óbreyttri jöfnun par sem aðgerðin er sniðin pannig að hækkun miðprósentunnar vegur upp lækkun grunn-prósentunnar og peir sem hærri tekjur hafa greiða pví óbreytta skatta, með óbreyttri prósentu hátekjuprepsins og óbreyttri jöfnun. Kerfið verður í kjölfarið með 4 tröppum (að teknu tilliti til skattleysismarka), minni jöfnun fyrir pá tekjulægstu (lægri trappa), meiri jöfnun fyrir millitekjufólk (hærri trappa) og óbreyttri jöfnun peirra sem hæstar tekjur hafa. Pannig verður tröppugangurinn skarpari og jöfnunin er í ríkari mæli borin af tröppum kerfisins og í minna mæli af persónuafslættinum sem ívilnar peim sem lægstar tekjur hafa. Ráđstöfun pessi er af hálfu fjármála- og efnahagsráđuneytisins kostnaðarmetin sem lækkun skatttekna sem nemur 21 milljarði á ári á verðlagi ársins 2021. 


\section{Lokaord}

Skattamál eru ávallt til umræðu og í eðli sínu hápólitískt og gildishlaðið viðfangsefni. Stærstu deilurnar frá upptöku staðgreiðslunnar hafa einkum birst í próun persónuafsláttar og skattleysismarka. Próun sem með batnandi kjörum hefur almennt pyngt skattbyrði pegar aðrar breytingar á skattprósentum stóðu óbreyttar. Ísland hefur verið með minnsta fjölda skattprepa á Norðurlöndunum og jöfnunin hefur í ríkari mæli verið borin af persónuafslættinum en á hinum Norðurlöndunum. Hár persónuafsláttur kallar á háa skattprósentu og grunnprósentan hér hefur almennt verið mun hærri en annars staðar á Norðurlöndunum. Um leið hefur tenging persónuafsláttar við vísitölu neysluverðs og efri markanna við launavísitölu verið umdeild enda pótt tengingin stuðlaði að sjálfvirkri sveiflujöfnun. Raunskattskrið er aldrei vinsælt.

Með lækkun persónuafsláttar og upptöku nýs neðsta preps má segja að stjórnvöld hafi beint norrænni nálgun við breytingar á skattkerfi par sem jöfnunin er í ríkari mæli en áður borin af prósentum en persónuafslætti og fyrsta prepið lækkar markvert pannig að tröppur pess verði skarpari en áður. Um leið er tenging fjárhæða skattkerfisins til pess fallin að stuðla að sjálfvirkri sveiflujöfnun án pess að til purfi raunskattskrið á lengri tíma.

\section{Heimildir}

Alpjóðagjaldeyrissjóðurinn (2015). Optimal Reform and Distributional Analysis of the Personal Income Tax. Washington D.C.: Albjóðagjaldeyrissjóðurinn.

Axel Hall. (2015). Taxes and employment in the Nordic countries. Reykjavík: Háskólaútgáfan.

Axel Hall og Gylfi Zoega. (2014). Values and Labor Force Participation in the Nordic Countries. Economics: The Open-Access, Open-Assessment E-Journal, 8 (2014-41), 1-43.

Barth, E. o.fl. (2014). The Scandinavian model-an interpretation, Journal of Public Economics, 117, útgáfa C, 60-72.

Blundell, R. \& MaCurdy, T. (1999). Labor supply: A review of alternative approaches. Í Ashenfelter, O. C., \& Card, D. (ritstj.), Handbook of labor economics (bls. 1559-1695). Elsevier.

Boadway, R. (2004). The Dual Income Tax System - An Overview. CESifo DICE Report 2 (3), 3-8.

Cahuc, P., \& Zylberberg, A. (2004). Labor Economics. Cambridge, Massachusetts: The MIT Press.

Decoster, A., O Loughrey, J., Donoghue, C. \& Verwerft, D. (2010) How Regressive Are Indirect Taxes? A Micro Simulation Analysis for Five European Countries', Journal of Policy Analysis and Management, 29 (2): 326-350.

Duclos, JY. (2008). Horizontal and Vertical Equity. Í: Durlauf S.N., Blume L.E. (ritstj.), The New Palgrave Dictionary of Economics. Palgrave Macmillan, London.

Fjármálaráđuneytið. (1997). Skilabréf og greinagerð jaðarskattanefndar. Reykjavík: Fjármálaráđuneytið.

Fjármála- og efnahagsráðuneytið. (2019). Endurskoðun tekjuskatts og bótakerfa hjá einstaklingum og fjölskyldum. Reykjavík: Fjármála- og efnahagsráðuneytið.

Friðrik Már Baldursson, o.fl. (2008). Íslenska skattkerfið: Samkeppnishæfni og skilvirkni. Reykjavík: Fjármálaráðuneytið.

Ganghoff, S. (2005). Adjusting National Tax Policy to Economic Internationalization: Strategies and Outcomes. Í Sharpf, F.W., and Schmidt, V.A. (ritstj.), Welfare and Work in the open Economy: Diverse Responses to Common Challenges, (Vol.II), Oxford: Oxford University Press.

Hannes H. Gissurarson. (2007). Jöfnuður og sanngjörn skattlagning. Stjórnmál og stjórnsýsla, 3 (2), 211-229.

Jakobsson, U. (1976). On the measurement of the degree of progression. Journal of Public Economics, 5, 161-168.

Jóhannes Karlsson \& Thórólfur Matthíasson. (2015). Tax Evasion, Tax Avoidance and the Influence of Special Interest Groups: Taxation in Iceland from 1930 to the Present. Nordic Tax Journal, Issue 2.

Lassen, D.D., \& Sörensen, P.P. (2002). Financing the Nordic Welfare States: The Challenge of Globalization to Taxation in the Nordic Countries. Kaupmannahöfn: Nordic Ministerial Council.

Lodin, S.O. (2011). The Making of Tax Law - The Development of Swedish Taxation. Uppsala: Iustus Förlag AB.

Musgrave, R.A., \& Thin, T. (1948). Income tax progression 1929-1948. The Journal of Political Economy, 56, (6), 498-514.

OECD. (2006). Fundamental Reform of Personal Income Tax. no. 13 OECD Tax Policy Studies. Paris: OECD.

OECD. (2009). Taxing Wages. Paris: OECD.

OECD. (2011). Taxing Wages. Paris: OECD.

OECD. (2013). Taxing Wages. Paris: OECD.

OECD. (2018). Taxing Wages. Paris: OECD.

Stefán Ólafsson og Arnaldur Sölvi Kristjánsson. (2012). Próun tekjuskiptingarinnar á Íslandi 1992-2010. Stjórnmál Es stjórnsýsla, 8 (2), 39-71.

Stefán Ólafsson, (2007). Skattastefna Íslendinga. Stjórnmál \& stjórnsýsla, 3 (2), 231-263. 